\title{
NATURE'S: CALENDAR
}

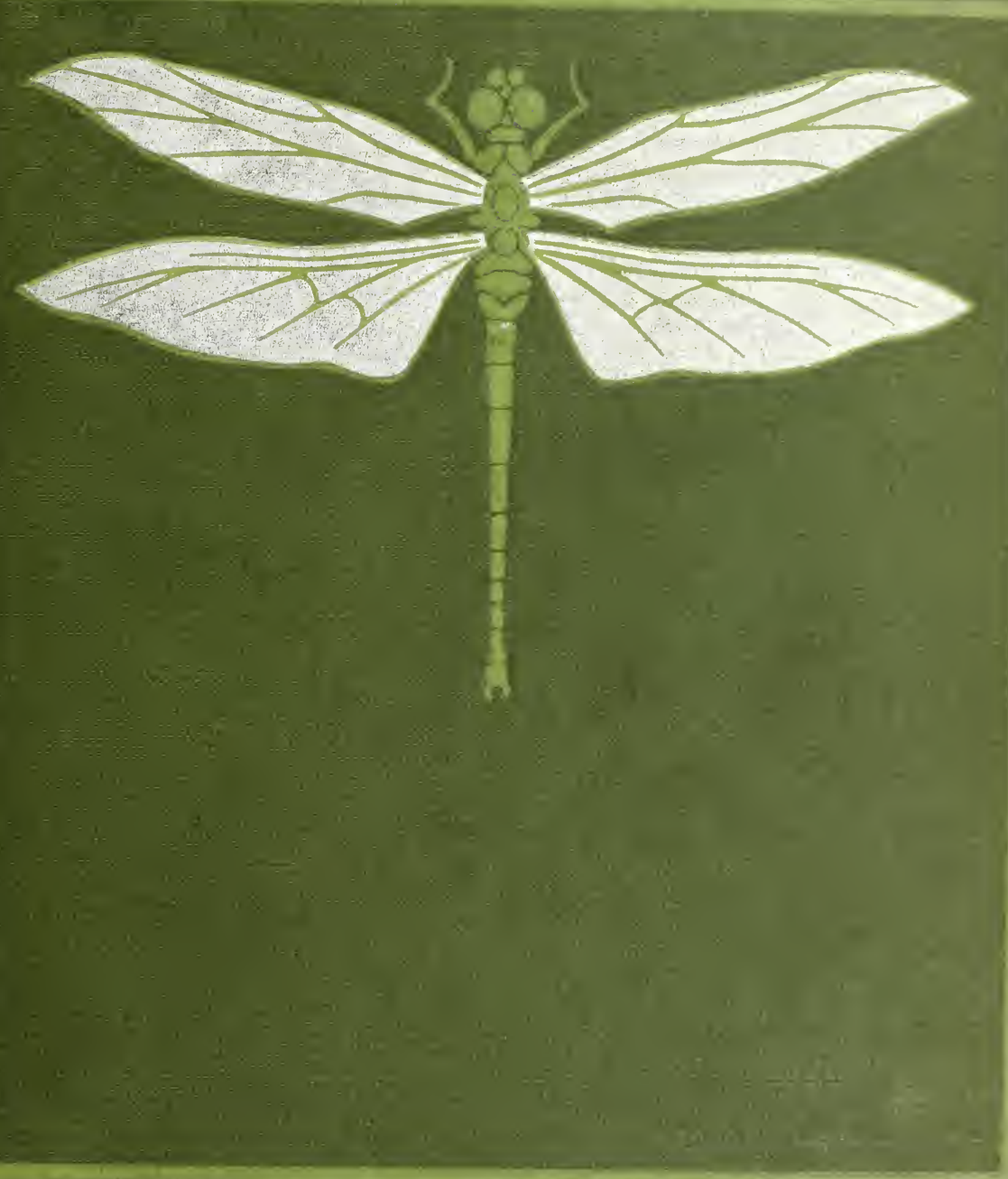

\section{ERNEST·INGERSOLL}




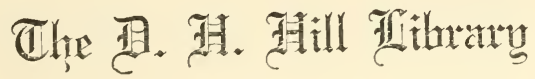

Diortly Curaliua Sstate College

$$
\begin{gathered}
\text { QH81 } \\
147
\end{gathered}
$$




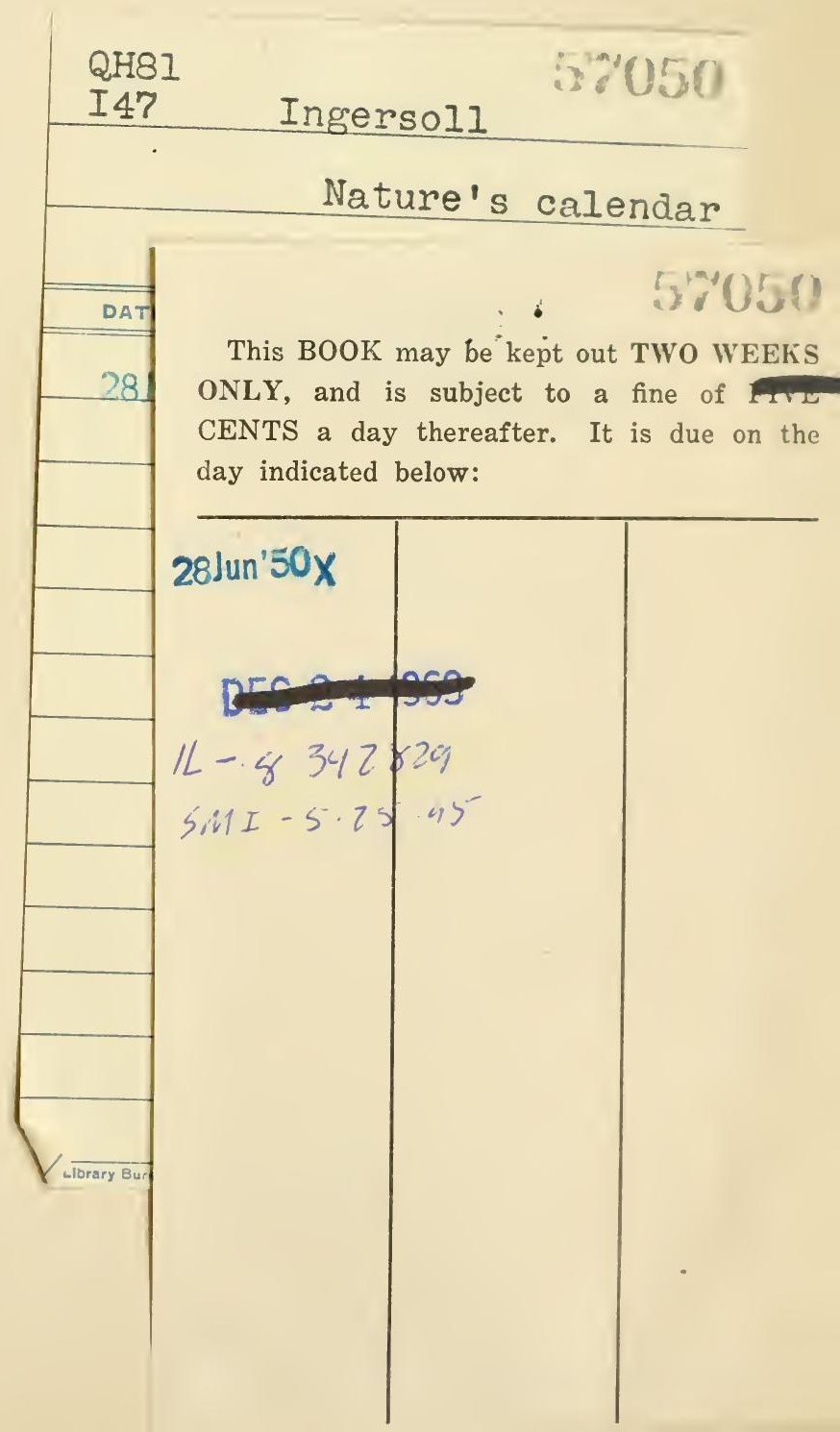






\section{Nature's Calendar}

by

ERNEST INGERSOLL Author of "Friends Worth Knowing" "The Ice Queen "

New York and London HARPER \& BROTHERS PUBLISHERS $M C M$

A Guide and Record for Outdoor Observations in Natural History

With Twelve Illustrations from Original Pbotographs by Clarence Low'n 


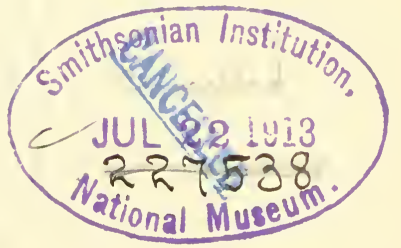

Copyright, 19co, by ERNEST INGERSOLL All rights reserved. 


\section{CONTENTS}

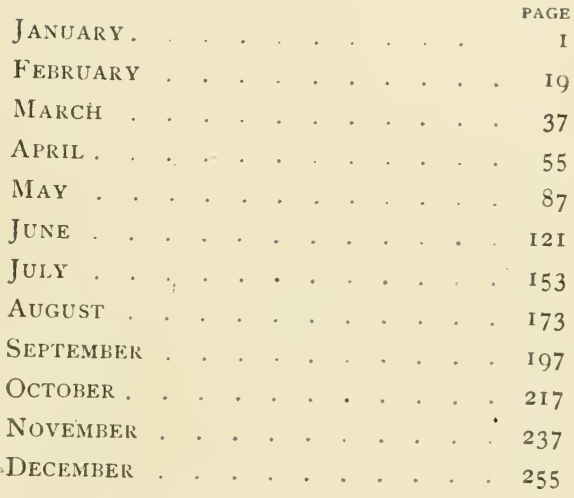




\section{$-$}




\section{EMBELLISHMENTS}

\begin{tabular}{|c|c|}
\hline & PAGE \\
\hline $\mathrm{RY}$-Poppletown Bridye. & xiv \\
\hline Y-The Snowy Path & IS \\
\hline RCH-Black Creek's Reluctant Fette & 36 \\
\hline PRIL-The Joyous Freshet & 54 \\
\hline Lay-Pastures New. . . & 8 \\
\hline UNE-Tangles of Larrel & I2 \\
\hline uly-Precious Shadon's at Noonday & 15 \\
\hline Ugust-By Cool Water-brooks. & 17 \\
\hline EPTEMBER-The Hush of Maturity & 19 \\
\hline Cстовев-A Mirror of Glories. & 21 \\
\hline ToveMber-Good-bye to the Wood: & $2 j 6$ \\
\hline ECEMBER- 7 & \\
\hline
\end{tabular}




\section{INTRODUCTION}

Observation is at the basis of all scientific work, and is itself both a Science and an Art, although, after all, it is nothing more mysterious than the faculty of keeping open at the same time both the eyes and the mind.

This little book does not pretend to teach it-perhaps no book can do that. It does attempt, however, to save you valuable hours and fleeting opportunities by reminding you from time to time throughout the circle of the year what is doing then in the living world, by giving you a memorandum of some things for which you ought at that moment to be on the lookout, lest their brief period pass before you learn or remember that this is their appointed season. In this respect it is a guide to study out of doors-a calendar of Nature's annual cycle of birth, career, death,
"For to be a Toaturalist, you maun hegin wi' natur'. "- Öhe Sttrick ofhepherd.
What to see and when to see it. 
and progeny-seed, blossom, fruit-

Poferences to the Tortheastern age.

The dates given refer to an ordiYbnited States.

Focozd the handmaid of Observation. nary season in the region about New York City. It was necessary to take some one district for the sake of relative uniformity, but the limit has not been strictly drawn, and the book will be found useful throughout the eastern half of the United States and Canada-at least, since an observer anywhere may act upon its suggestions, quickly learning how to make local allowances for his own circumstances of latitude and climate. In doing so he will begin to understand the pleasure of his work, and will call it play.

But observation without record falls short of its possibilities for both value and enjoyment. Memory will retain general impressions and the larger outlines, but ought not to be trusted for exact details, and will soon be overtaxed. Nothing is more important, and soon nothing becomes more amusing, than the making of field-notes day by day; and they will surely be treasured for the pleasant Ficld-notes a treasury of happyzc- associations they recall-a record ollections. full of the sunshine of summer days, 
the singing of birds, the gayety of butterflies and blossoms, the aroma of the woods, and the plash and sparkle of waters.

Should these notes be continued through a series of years, so that one season may be compared with another, their worth and interest will accumulate in a compound ratio. Said Thoreau :

"A man must attend to Nature closely for many years to know when, as well as where, to look for his objects, since he must always anticipate her a little. Young men have not A3 thought from the poet-naturalist of Malden.

learned the phases of nature. They do not know what constitutes a year, or that one year is like another. I would know when in a year to expect certain thoughts and moods, as the sportsman knows when to look for plover."

This is a glimpse of the higher, poetic range of our subject - the heaven which cometh by observation.

It is in view of the fact I have dwelt upon-namely, that observation and record should go hand in hand, one complementing the other, that the dated margins have been left in this book, running continuous with each out-dooz life.

Dated margins for a diary of your 
Ef boon to others as well as to youzself.

Ef fireside session of the Mroarginalia Olub. month's suggestions and calendars, so that you may conveniently write down day by day, as often as you please, a summary of what has come before your eyes and mind, and thus at the close of the year find your volume doubled-its roomy pages stored with your own increase of facts, impressions, musings, and sketches, set in orderly array.

This may possess double worth. It is well known to book-lovers and to the collectors of rare volumes that the value of an old book is enhanced in most cases when its margins show annotations by its owner; and that such books more often than others are kept as precious heirlooms or are lovingly placed in the security of historical collections. What an opportunity, then, to distinguish one's self in the eyes of grateful grandchildren do these fair margins present!

But such marginalia, however attractive they may become in a backward perspective, will have a present and continuous worth and interest to the maker. One might imagine that a collection of these marginal field-notes jotted down by neigh- 
bors, when brought together, compared, and considered, around the open fire of a wintry evening, or in an occasional half-hour in the schoolroom, might go far not only to revive the sense of the past summer, but might make no mean substitute for a session of a local society of natural history; or that an interchange of such annotated books between persons living in different places and conditions might furnish hours of profitable enjoyment to both, and be mutually stimulative in a high degree; or even that a "nature study" class might make capital of last year's well-filled volumes in carrying on the present year's work.

In fact, if you will regard the printed part as nothing more than my beginning, and will complete it and correct it for your own locality in the blank spaces left to you for that purpose, you may find yours the better half of the book, and I shall not begrudge you either the esteem or the glory of it.

In making this little book I have received assistance from several persons, whose help I wish gratefully to acknowledge.

Jnformation for exchange.

Yours the better half of the book, its likely as not. 
The Bresbyterian Soard of Bublication.

Diof. Glarence 96. RPed.

Tl̈iss Foiden cingersoll.

MÖ. Blazence Lown.
The germ of the book lay in a series of articles contributed during 1899 to Formard and Wellspring-juvenile periodicals of the Presbyterian Board of Publication; and my thanks are due to that Board for permission to use so much of the material as was desirable for the present purpose.

Prof. Clarence Moores WVeed, of the New Hampshire College of Agriculture and the Mechanic Arts, has rendered valuable assistance in respect to insect-facts, the monthly calendars of insect life coming wholly from his knowledge and pen.

I am similarly indebted to $\mathrm{my}$ daughter, Miss Helen Ingersoll, for help in respect to local botany, credit for the paragraphs relating to the annual procession of plant life mainly belonging to her.

Finally, I wish to thank Mr. Clarence Lown, of Poughkeepsie, for the use of twelve of the photographs that have been made by him from time to time in the Hudson Valley, and which illustrate, by suggestion as well as by scene, the progress of a rural year in the Eastern States. 


\section{JANUARY}

"The winter's icy fingers clutch at the rushing brooks, Freezing the stream that lingers in coves and placid nooks." 



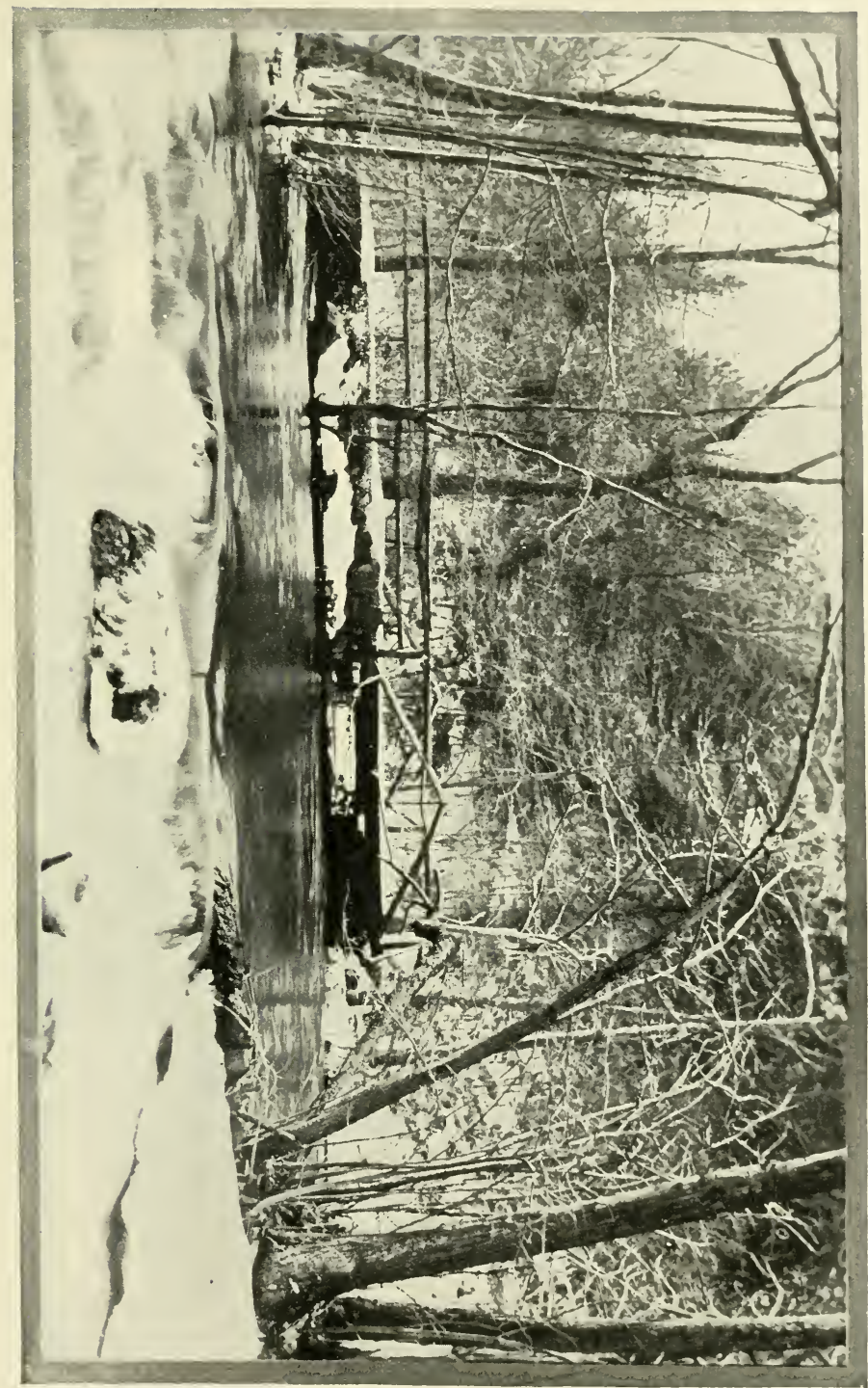




\section{NATURE'S}

CALENDAR

\section{JANUARY}

IT is a fortunate thing for our purpose that the beginning of the calendar year is January I made to come in midwinter, as it now does throughout Christendom. January, as its name implies, is truly a month of retrospect and of prospect, the dead-point of the circle of the seasons, the time when nature rests preparatory to renewing its labors. It is a larger night, a period of quiet and repose. But nature is not dead, only sleeping, since its work is done for the present. The foremost natural duty of all living beings, "to multiply and replenish the earth," has been performed. Plants have sprung up, put forth leaves, displayed their flowers, ripened and distributed their seeds, and, " neither hasting nor resting," have fulfilled their destiny. If they were herbs they withered and died, trusting to the seeds they had perfected to bring up their like next year; if they were of the sturdier sort then their roots 
survived, or, in the case of shrubs and trees, their whole woody framework, but their leaves fell to the ground, giving way to plump buds kept warm by many scales. It is a part of the silent duty of January to dissolve and absorb the good in these discarded leaves and worn herbage, and to mingle it with the soil, helping the earth to recuperate strength for the labors that must soon be renewed.

Meanwhile the water carrying the sap, which contains the food and buildingmaterial of the tree, ceases to flow into the branches, so that one may say that its veins are drained of their blood. The soft layer of new wood beneath the bark hardens, and there is no danger of damage from freezing.

The snow which now covers the earth plays a beneficent part towards vegetation. It is like a blanket, keeping in the warmth, preventing excessive freezing of the ground, protecting it against a too rapid evaporation of its moisture, and by its occasional melting contributing evenly to the soil the water stored in its glistening crystals.

The vegetable world, then, rests and sleeps in our January days. The same is extensively true of the animal world. Most creatures of the lower types die out altogether in the autumn, like the annual plants, leaving only their eggs or young to renew the tribe when warm weather returns, yet some of the simplest as well 
as of the highest organization survive by stopping all activity. Thus most of the minute creatures that crowd our ponds and ditches seem to have as much hardihood as the water weeds amid which they dwell, so that the fishes under the ice have no lack of winter food. They themSEIves feed upon minuter and even microscopic plants, upon hydroids, eggs of various diminutive creatures, of which at this season many are being produced in the water - those of the fresh-water polyps, for instance-and other smallest of small fry. Earthworms and their kin. dred bore into the ground until they are below the line of frost, or if they are of aquatic habits bury themselves deep in the muddy bottoms of streams and ponds; while the water spiders keep comfortable, after the weather has become too cold for them, by sleeping in the bubble of air they are able to take down with them, entangled in the long hairs of their legs and bodies. In the Southern States, of course, these precautions against the climate are much less necessary or prolonged than in the colder region northward.

Land spiders pass the winter in more or less activity, according to their natures and the degree of cold. You may find some abroad any day this month, even running about on the snow, but for the most part they are hidden away in our cellars or under stones or logs. The burrowing species, such as the trap-door spi- 
January 6 ders, remain within their snug, silk-lined houses, rarely going out from November to April; and if you were to put a thermometer into one of their tubes you would find it comparatively warm. Mrs. Mary Treat tells us that she found the "parlor" of a large trap-door spider in her yard to have a temperature of $40^{\circ} \mathrm{F}$. when the outside air was only $20^{\circ} \mathrm{F}$. above zero. It is during this winter confinement that their eggs are produced, and when the females emerge in April each brings with her a sack full of eggs attached to her spinneret.

As for the mollusks, those that live in the sea simply crawl into greater depths as the water cools along the shore; or they keep beneath the ice when, like our various river mussels and pond snails, they inhabit fresh waters. There is no doubt, however, that shell-fish can endure extreme cold as well as excessive drouth. One sort certainly is obliged to do so in our northern climate-the land snail.

If in midwinter you pry apart mouldering logs, overturn deeply embedded stones, or search about out-house cellars, you may find any number of these familiar little mollusks of our gardens, quiet but in good hea!th. It will be noticed, however, that all lie with the aperture or "mouth" of the shell upward, and probably glued to a support; and also that this aperture is always closed by a whitish membrane of hardened mucus which closes it like a 
drumbead. The snail has filled his house with air, then closed his door with an airtight curtain, and gone to sleep. Perhaps he makes a second or even a third screen inside of it, to guard against any accident breaking the outer one, which would be fatal to him. The breathing and circulation of the blood of these hibernating snails seem wholly to cease-at least a chemical test will show that the air inside the shell is as pure as that outside; but it seems necessary that it should not be disturbed. Mere cold, however, appears to have no harmful effect.

Rising another step, we encounter among the insects some curious facts. The best that most insects can do on the approach of cold weather, which means famine for them, is to dic; so that in this month a collector can find little to add to his cabinet, except in the way of inmature forms. It is doubtful whether any fully developed neuropter could be picked up in January, with one remarkable exception-the snow insect, a curious wingless, caterpillar-like little creature, about as long as a grain of rice, and orange red or shining black, according to species; it dwells in the moss and is rare, but when seen at all, it appears in great numbers hopping about on the snow in sunny places.

In the group of orthoptera-the cockroaches, crickets, locusts, and the like-a few adults may be gathered. The bur- 
rowing crickets might be dug out of their burrows, if we knew where they were, and a good many locusts and grasshoppers hibernate in sheltered places. Among the true bugs (Hemiptera) far too many are alive all winter, for here come the various lice and scale insects infesting trees and fruit, and many other unpleasant forms. Of larger sorts, most perish with the first frosts, but here and there an adult will hibernate successfully, and of the aquatic forms a large proportion remain at the bottoms of their ponds, ditches, and streams all winter, torpid in the mud about the plant roots, or perhaps active.

Beetles, from the nature of their structure, are more hardy, and a great many survive in the imago form from autumn to spring, though tivese form only a small proportion, after all, of the total. The ladybirds, for example, hibernate numerously under bark, in barns and similar wooden places of shelter, as also do the flea-beetles so injurious to grapes. The potato beetles and allied forms, such as the asparagus beetle, burrow down below the frost-line and become torpid; one apple-borer (Amplicerus) cuts out a winter-chamber for itself in the tree-wood; and weevils hibernate largely as imagos, creeping into crevices of bark, under rotting leaves, or anywhere else that seems to them snug. Examples of many smaller kinds, then, might be taken in midwinter by a diligent collector, but of the large, 
hard-shelled beetles few survive the cold months of the Northern States.

Not many of the flies last from one year to another, except a few around warm houses and stables, but many of the butterflies are hardy enough to survive January frosts. Several species of the common brown $V$ anessa, especially $V$ anessi antiopa and $V$. progne, spend the season under logs, ledges of rocks, etc., and the appearance of a warm, thawing day will bring them, and other insects, into temporary activity. The delicacy of these creatures does not prevent their enduring severe cold; moths and butterflies may be found in the arctic regions, or upon the freezing, stormy peaks of the highest mountain ranges. Such, among American butterflies, are the grass-feeding species of the genus Erebia, whose chrysalids are placed for the winter upon the ground; those of the genus Eneis, called "arctics," also brown and grass - eating, one of which is a famous Mount Washington species (Eneis semidea), which dwells on the naked summits of the Presidential Range in the White Mountains, where it is regarded as a relic of the glacial period, when an arctic climate prevailed as far south as central New Hampshire. Another Mount Washington butterfly, Brenthis montinus, has a similar history, and represents a third genus of small butterflies able to endure arctic cold.

Some species of these tribes may be 
found along the northern border of the United States, and are sometimes collected in midwinter. "Some arctic species [of butterflies] are known in which the development from the egg to the perfect insect covers a period of two or three years, long periods of hibernation under the arctic snows taking place."

Such highly organized, long-lived aristocrats among the insects as the bees, wasps, and ants, most of whom live either in well-built community houses or in burrows, where they store provisions and are warmly sheltered, get through an ordi nary winter with little trouble or suffering, sleeping away the coldest parts of it in semi-torpidity. Of course, the farther south you go the more numerous and active are these and all other insects, though insects are much more scarce in winter than in summer, even in the borders of the tropics. But, after all, the rast majority of insects, taking all kinds together, die off in the autumn, so that in thousands of groups not a single adult indiridual exists when the first snow comes.

How, then, is their race maintained so that they appear as numerously as ever upon the return of warm weather? In this way: The females lay eggs. Sometimes these hatch quickly into larvæ (or grubs) and these become pupæ (chrysalids in a cocoon), and perhaps by that time, if the species be double-brooded the mother has deposited in some suitabie place a 
second lot of eggs. One or the other of thesc undeveloped forms of these insects, or perhaps all three of them, in separate places and under varying circumstances, will last through the cold months and be ready, if they be eggs, to hatch out at their proper time in the next spring, or, if they be grubs or chrysalids, to develop into imagos, or full-fledged insects.

One who searches for insect eggs in January may find them in almost every conceivable place-glued to bark and twigs: hidden away beneath the bark, among fallen leaves, and in piles of decaving rubbish, at the bottom of holes in wood or the ground, drilled for the purpose by their careful parents; or hatching in the bodies of other insects or larvæ.

As for the grubs, their winter sleepingplaces are equally varied and innumerable. A large variety of beetle grubs inhabit holes in the soil below the frostline, where they feed upon roots, when they feed at all. Another large class, hatching from eggs placed in wood, either rotten or solid, gnaw a chamber for themselves, and remain dormant there until the time comes to make their escape: others dwell in heaps of manure or rotting vegetation, or loose sand. Some of them seem to care little for protection from cold, and keep wide awake when most of their neighbors are dormant. The velvety larvæ of the American fireflies of the Telephorid family are often seen wander- 
ing in large numbers on the surface of the snow, giving rise to stories of showers of worms; and cases are recorded where grubs have been frozen solid, so that you might break them in two, like icicles, and yet were restored by thawing-not the broken ones, of course, but those left to nature's restoration. It must be added, however, that careful entomologists doubt these statements somewhat, and fresh and very cautious experiments are desirable.

"Many caterpillars which hibernate do so immediately after emerging from the egg, and before having made the first molt. The great majority, however, hibernate after having passed one or more molts. With the approach of spring they renew their feeding upon the first reappearance of the foliage of their proper food-plant, or are transformed into chrysalids and presently emerge as perfect insects." So says Mr. Holland.

Among the higher insects, especially the beetles, moths, and butterflies, the chrysalid is the form that most usually carries the species through the inactive season of the year, the clothes-moth furnishing a very familiar instance.

Some lie in the ground or beneath rubbish, furnishing an argument for tidiness about our houses and gardens, and late and early cultivation of the soil, in order to discourage and destroy the propagation of injurious and annoying pests. The tiger beetles seem to have the unusual 
method of spending the winter as pupa in the burrows they dug and used as traps and retreats when they were in the fierce grub stage. A good many chrysalids, especially of the smaller beetles, hibernate among the shreds of rotten stumps and logs, or beneath the loose old bark of trees, and in crevices about fences and houses; while the infant moths and butterflies are safely wrapped in warm cocoons, which are stowed away in all sorts of snug corners, or glued to the bark of trees, or on the sheltered sides of stones, logs, fence rails, etc., or else hung, like cradles, to the stems of their favorite plants. This, therefore, is a good season to gather cocoons, allow them to develop in captivity, and study the process.

This ends the list of invertebrates, and we are now ready, during the continued cold weather of February, to study how the higher, vertebrated animals care for themselves in winter. 


\title{
CALENDAR FOR JANUARY
}

\author{
MAMMALS \\ (See Calendar for February) \\ BIRDS
}

The list here given is practically a catalogue of the winter birds in the vicinity of New York, including both the permanent residents and the winter visitors from the North.

Grebes and Loons. - Occasionally seen.

Auks, Murres, Jesers, etc.-Casual visitors to the coast.

Siaddle-backed Gull.-Common on the coast. Herring Gull. - Abundant in all harbors. Ringr-billed Gull.-Common along the coast. Shelitrakes.-Uncommon visitors.

Black Duck.-Common along the sea-coast. Golden-eye, or Whistler. - An irregular visitor. Buffle-head.-Common in suitable places. Old Squaru, or Olt It ife Duck.-Common. Scoters.-Three species, irregularly present. IVoodiock.-Occasional at favorable places. Bob IVhite.-Common all the year. Ruffed Grouse. - Common all the year. Sharp-shinned Hawk. - Common always. Cooper's Hazvk.-Rarer than the sharp-shin. Goshawk.-A rare winter visitor.

Red-tailed Hen-hawk. - Less numerous than in summer.

Red-shouldived Hawk.-Common all the year. Bald Eagle.-A permanent resident; often seen on the ice in the Hudson River.

Duck-laawk.-Seen occasionally about the Hudson palisades. 
Sparrow-hawk.-Uncommon bit resiclent. Long-eared Oi'l. - A permanent resident.

Short-eared Oiel.-Occasional, about marshes. Barred Oivl. - A numerous permanent resi(ient, frequenting barns and hay-lofts.

Sazu-whet, or Acadian Oiwl.-A rare visitor.

Screech Oivl.-The most common of the small owls all the year round.

Great Horned Ozol.-Not uncommon.

Snowy Owl._A Appears at long intervals.

Hairy Woodpecker. - A permanent resilent. Downy Woolpecker.-Abundant all the year. Red-headed IVoodpecker.-Formerly common, but now rare east of Central New York.

Flicker, or Golden-winged IVoodpecker.-A few remain in mild seasons.

Horned Lark, or Shore Lark.-Occasional along the coast.

Blue Jay.-A permanent resident ; more conspicuous now than in summer.

Crow.-Abundant, especially near the coast. Meadow Lark. - A few usually to be found.

Pine Grosbeak.-Irregular; among evergreens.

Purple Finch.-Irregularly present.

American Red Crossbill-Usually numerous.

White-winged Crossbill.-Occasionally seen.

Rédpoll. - Irregular visitor; occasionally abundant.

Goldfinch.-Common in small flocks along roadsides, and habited in dim plumage.

Pine Siskin, or Finch.-Irregularly present.

European Goldfinch. - Becoming numerous near New York and Boston.

Snowflake, or Snow Bunting.-Usually present, especially along the coast.

Lapland Longspur. - Casual, in company with snowflakes. 
Vesper Sparrow, or Grass Finch. - Often present in New Jersey.

White-throated Sparrow. - A few occasionally. Tree Sparrozu, or IVinter C'hippy'-Common. Snoze-bird (Junco). - Abundant and familiar. Song Sparrow-Permanent resident; less numerous than in summer.

Sreamp Sparrow,-Occasionally remain.

Cardinal.-Rare and occasional.

Cedarbird, or IVaxaing.-Common.

Northern Shike, or Butcher-bird._A not uncommon visitor, but irregular.

Winter $\mathrm{W}$ ren.,-Fairly common visitor.

White-breasted Nuthatch.-Common.

Red-breasted Nuthatch.-Irregular visitor.

Tufted Titmonse.-Permanent resident in New Jersey.

Chicadee.-Abundant permanent resident.

Golden-crorined Kinglet.-A common visitor. Robin.-A few usually to be found.

Bluebird.-A permanent resident.

FISHES, REPTILES, ETC.

(See Calendar for February)

\section{INSECTS}

Hornets and Yellow. Jackets.-Queens in old nests.

Broain IVasps.-Queens in attics and under loose bark.

Bumble-bees.-Queens in last year's nests.

Mud-wasps and Disger IVasps.-Pupæ in mud cells or cells in earth.

Ants.-Queens and workers in colonies mostly underground.

Ichneumon Flies and other Parasites._Some 
hibernating as adults in shelter of various sorts; others in earlier stages.

Currant Worms. - In cocoons on ground beneath currant bushes.

Ground Beetles.-Adults under stones, logs, boards, or similar shelter.

Buprestid Beetles.-Flattened larvæ boring in trees and logs.

Ladybird Beetles. - Adults hibernating under fallen leaves, about stumps, or other places. Often many together.

May Beetles or "June Bugs."-As larvæ (white grubs) in soil of grass lands, or as adult beetles in pupal cavities.

Click Beetles.-As larvæ (wire-worms) in soil or as fresh adults in pupal cavities.

Longicom Beetles. - As cylindrical larvæ boring in trees and logs.

House Flies. - Adults in attics, sheds, etc.

Crane Flies.-Larvæ (leather-jackets) in soil of grass lands.

Gall Flies.-Larvæ of many species of gallmakers in galls on willow and other plants. Mourning Cloak, or Antiopa Butterfy, and other related species. - Adults in wood-piles, brush-piles, hollow trees, or other shelter. Asterias Butterfly and Cabbage Butterflies.Chrysalids attached to fences and buildings.

Viceroy, or Disippus Butterfy.-Larvæ in silken cases on willow and poplar twigs.

Sphinx Moths. - Pupæ in soil.

Cecropia and Promethea Moths. - Pupæ within silken cocoons attached to twigs.

Polyphemus and Luna Moths. - Pupæ in cocoons on ground beneath food-plant.

Cutworm Moths, - Larvæ in soil about grass roots or under boards, stones, or logs. 
White-marked Tussock Moth.-Egg-masses on old cocoons on bark of elms and maples.

Fall Cankerworm.-Egg-masses on twigs of elm and apple trees.

Leaf-crumpler.-Larra in masses of leaves attached to apple and other trees.

Budiunms. - Larva in brown cases hidden beside the buds of apple-trees.

Leaf-miners. - Larvæ of many species in hanging or fallen leaves.

Ciddis-fies.-Larvæ in cases, in ponds, etc.

Hellgrammite Flies.-Larræ (Dobsons) in rapids of streams.

Squash-lungs and similar species.-Adults under boards, sticks, logs, and similar shelter.

Witer-buss.-In ponds, streams, or mud.

Cicadas.-Larve in the ground.

Tree-hoppers. - Eggs on twigs and shrubs.

Leaf-hoppers. - Adults in grass and litter.

Scale Insects. - Scales on trees and shrubs.

Plant-lice._Eggs on trees, especially about buds; of some species in ants nests.

Locusts, or Grasshoppers. - Eggs in ground.

Gronse-locusts. - Adults beneath fallen leares, especially along borders of woods.

Tree Crickets. - Eggs in canes and twigs.

Black Crickets. - A few half-grown specimens about stumps, but most in egg-state in the soil.

IV alking-sticks. - Eggs scattered under trees.

White Ants. -Colonies in ground in or stumps and $\log$ s.

Stone-fies.-Larva under stones in water.

Dragon-fies and May-fies. - Immature forms in ponds and streams.

Springtails and Bristletails.-Under boards, $\operatorname{logs}$, and stones. Sometimes appearing on the snow (snow-fleas). 
FEBRUARY 


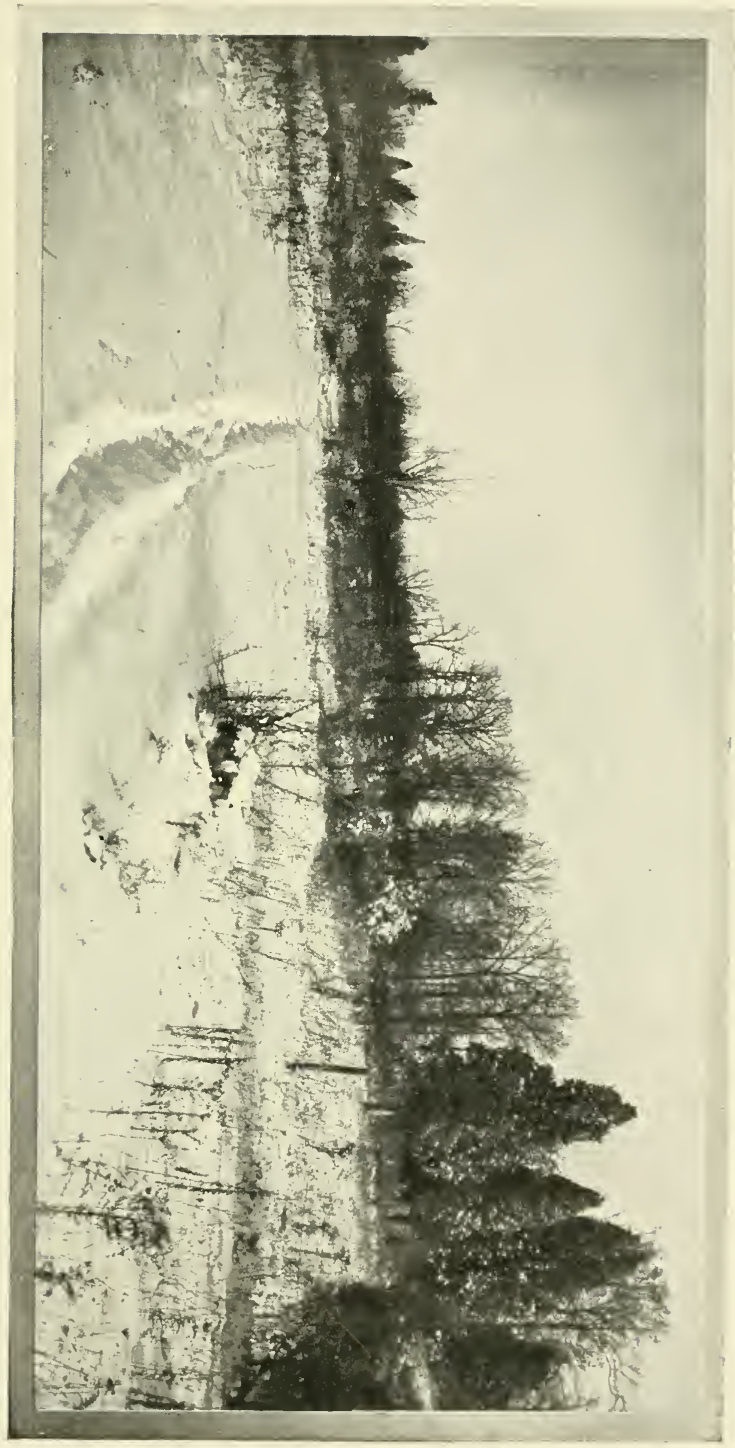





\section{FEBRUARY}

FEBRUARY, in the northern and middle portions of the Union, is still uninterrupted winter--often the worst of it. The Romans gave this month that name, meaning "purification," in reference to certain ceremonies and festivals that fell within it; and we still might fancy, when the temperature sinks far below the freezing - point and stays there for days together, and night after night adds a fresh sparkle to the earth's winding sheet of snow, that this was a feast of purification for nature. In fact, it is so, air, water, and earth being cleansed, disinfected, made sweet and wholesome by February's cold.

Nature is still resting and recuperating in the long sleep begun in December, but the good that it is doing her we cannot easily see as we walk abroad, unless we make careful and continuous observations; for February, north of the Ohio River, at least, must be nearly passed before we can perceive the first "sign of spring" that is openly encouraging.

There is plenty of life about, nevertheless, and as in my essay on January I 
gave an account of how the lowly, hidden, invertebrates of our woods and waters met this forbidding season, so now I mean to give some facts of the winter life of the higher kinds of animals, many of which enliven a landscape otherwise apparently lifeless.

The fishes have only to go into water so deep that it cannot be frozen to the bottom in order to escape discomfort, though it is certainly a time of less luxury with them than summer, when air and water are full of insects; on the other hand, they need less food for their diminished activities. At any rate, fishes exist in health and apparent happiness beneath the ice of the deeper rivers and ponds, as is well known to many who fish successfully, with both lines and nets, through the ice, though this is practised more in Canada and the country about the Great Lakes than in the East. It is done considerably upon the Hudson and its tributaries, however, nets similar to fykes, taken up and turned with each change of tide, being lowered for "scale fish "- that is, for striped bass, white and yellow perch, mainly, white suckers (scarcely edible at other seasons), goldfish, sunfish, tomcod (locally, the frost-fish), and frequently catfish of two or three kinds.

By line-fishing through the ice in the ponds and quiet rivers of New York and New England, one may catch pickerel in great numbers, black bass (the small-

\section{February 3}


mouthed one), yellow perch, white perch, and some others.

The sea-fishes taken in and about New York Bay and Long Island Sound this month are few, the markets being largely supplied with deep-sea fish of the cod family, and oysters and clams taking the place of local kinds.

In the ponds with the fishes dwell, in southerly waters, certain amphibians, like the repulsive mud-puppies, or sirens, that do not need to breathe air, and a good many late tadpoles, that are waiting until spring enables them to drop their tails and appear in land society as proper frogs. In fact, the marshes themselves are almost as full of frogs in silent February as in vociferous March, but they are all either lounging in deep spring-holes or else buried half torpid in the shore mud, along with the turtles; and once in a while, when a particularly warm spell rouses them out, we hear a few feeble and doubtful calls, as if asking one another why folks were getting up so early. As the toads cannot breathe through their skins, they would drown beneath the ice, and consequently must scramble down into dry soil as far as they can go and hibernate in these holes, with various salamanders for bedfellows; and once in a while the salamanders wander out, during the thawing days that often come in the latter part of this month.

The reptiles sleep away the winter in 
February 6

February 7 similar fashion. Rotten logs, stumps, and the insides of old trees make snug winterquarters for the two or three kinds of lizards that live where it is too cold to be abroad at all seasons, as they can be in the Southern States. The snakes, however, have an unpleasant way of gathering into a tangled, ball-like mass of a dozen or more, after collecting in some den deep in broken rocks, or underground-in an old badger-hole, for example.

Turtles and tortoises bury themselves for the season deep in the ground. So long as the weather remains steadily cold they stay there until a time in the spring varying with the different species; but some, like the painted mud-turtle and the speckled tortoise, will crawl out into the sun during a prolonged " warm spell."

This brings us to the birds and mammals of winter, and gives us something to see and study in our own gardens as well as out in the snowy woods and fields. "I am persuaded," exclaims Mr. William E. Cram, in his capital book, Little Beasts of Field and IV ood, "that most of us would be surprised to learn how many wild animals of the bigness of a cat and upward pass their lives in the midst of cultivated districts without ever having been seen by men. . . . In studying quadrupeds the chief thing to bear in mind is that, with the exception of squirrels and woodchucks, and possibly one or two others, all of them have comparatively 
poor eye-sight, at all events for daylight, and apparently not much better for twiFebruary 8 light or darkness... But with a sense of smell and hearing such as theirs, they are instantly aware of anything that takes place in their immediate vicinity, with the exception of the one point towards which the wind blows.... While the wind is at your back you will only get the most unsatisfactory glimpses of any of the fox or weasel tribe; but with it in the opposite direction you may study them at your leisure; and to a certain degree this is true of all our wild animals.

"In one sense winter is the best time for studying them, for when the snow is in the right condition you may follow the footsteps of all those that are abroad at that season, and see for yourself just how they have been spending their time."

Midwinter is the time when the fourfooted fur-bearers are at their best. The deer wander as widely as the snow permits, and frequently approach human settlements, mingling with cattle in search of fodder, and wearing their handsomest coats, which are paler and more bluish than those of summer. As the month comes to an end they begin to grow somewhat ragged, and the antlers loosen upon their heads. Among the wilder ranges of the Alleghenies, and in the forests about the upper Great Lakes and far Southern swamps, pumas and lynxes remain to remind us of the time when they 
February 10 were so common that it was difficult for the pioneers to keep their flocks and herds intact during the winter; and in very cold spells they still make occasional forays upon cattle-yard and hen-house. The small yellow wildcat is, indeed, to be heard of in winter almost everywhere; but the howl of the wolf, mingling with the whine of the wind as it hurtles the snow against the cabin window, no longer, as it used to do, adds an eerie sense of peril to the woodlander or prairie settler. The wolf's young brother, the fox, still barks at night on the glistening hill-tops, and his sharply cut track is seen by the villager in the early morning when he goes to the barn to milk. It resembles that of a large cat, but the line is straighter, the footprints farther apart, each showing four pads and the marks of the claws in front. The fox feeds at this season largely on white-bellied mice, but takes poultry and almost anything else he can catch. Even a bear (whose young are born this month in the middle districts) may now and then wander lazily about on warm days in sunny mountain valleys, and at night visit the pigsty or calf-pen of some lonely farm, driven by famine to a boldness and ferocity very unlike the placidity of the berry-and-insect-fed animal in summer.

One may also see the tracks on the snow of an occasional raccoon and skunk. though in the colder parts of the country 
all three of these are more inclined to sleep in their snug dens till February's blasts and snows are well out of the way - the bear in a rocky cavity, the coon in some holiow high up in a tree, and the skunk in a hole in the ground, a nest beneath a haystack, or, alas, in a warm corner under the stable, where we are sometimes most disagreeably aware of his being on foot. In the fastnesses where the beautiful otter still finds a harbor, he is actively abroad all winter, making long journeys over frozen rivers in search of open places where he may fish.

Another prowler in such solitudes is the bloodthirsty mink, who seeks and woos his mate in the latter part of this month or in the beginning of March. During the winter, however, minks seem to work alone, sleeping wherever they can find a snug ..corner at night, and spending the day in search of food, which consists mainly of earthworms and fish, which they pull out of warm spring-holes. Of eels they are especially fond-or perhaps these are most easily taken. "I know of one spring under the steep river bank," says Mr. Cram, “where the minks watch patiently until some unfortunate eel is brought into sight by the constant upward movement of the water, when it is quickly seized and dragged out upon the snow. But the struggle does not end here, for when the mink prepares to bear its victim away in triumph the latter is 


\section{February 14}

apt to wind its body around that of the captor, and generally succeeds in throwing him end over end more than once before being finally subdued and hauled away. ...

"A mink will nearly always follow any open brook it comes to, even if obliged to change its course in order to do so, alternately swimming and wading or walking along the bank. On reaching the linit of the unfrozen water, he will often keep on beneath the ice, especially if the water has fallen away from it so as to leave an air-space, and perhaps a narrow strip of turf uncovered along the edge of the water. For it is in just such places that meadow-mice spend the winter, their burrows opening out from the banks in the same manner as muskrat holes. And even the smallest brooks harbor young pickerel and eels, as well as frogs and lizards. . . . But the mink does not always confine himself to such insignificant game, by any manner of means: he not infrequently kills birds and animals as large or larger than himself, neither ducks, partridges, chickens, rabbits, or muskrats being ever wholly safe where minks are abundant."

The mink remains brown all winter, but with the coming of cold weather his cousin, the weasel, or ermine, turns more or less white according to the degree of cold - those in the soutl making no change of pelage at all. This is a com-

\section{February 15}


mon thing with far northern animals that are abroad in winter, and seems designed to make them less conspicuous on the snow. Thus the big northern hare turns white, but our common hares or rabbits of the central United States find it needless to do so, and become darker rather than lighter this month, like other furbearers, which often display tints and markings absent from their summer coat. This interesting phase of winter life will be treated of more particularly when we come to consider December.

This brings us to a family of smaller mammals, some of which are wide awake in February, while others stay fast asleep - the gnawers. The porcupine scrambles awk wardly about his northern woods now as well as when the blossoms are out, finding plentiful provender in the bark and leaves of evergreen trees, though even he is fain to hang himself in a dense tree-top during "cold snaps," and take a prolonged semi-torpid nap in which the question of food has no interest for him. The opossum behaves in much the same way, being fond of staying at home in his hollow tree, or under the barn, yet he wanders a good deal in mild weather in search of food. With this animal, however, ends the list of those able to support themselves in winter from day to day, with the exception of the shrews. which, though the tiniest of quadrupeds, are also among the most hardy. 
All other mammals within our range must lay up a store of provisions or else avoid the winter altogether by sleeping it out, or combine both methods of existence, varying them, of course, according to the comparative coldness of the district where they live. Thus the muskrat of northern latitudes heaps up in the fall a mass of more or less edible vegetation in the water near his burrow home in the stream-bank, making a cavity in the centre, which he can enter from beneath, and where he can stay above the water and eat when the weather or inclination forbid his leaving home. Thus, if other food fails, he may gradually devour his shelter or store-literally eat himself out of house and home. Both the muskrat and the beaver make long excursions beneath the ice, and strive to keep clear of frost certain breathing-holes and exits.

The gray squirrels construct big globular nests in hollow trees, or more often among the branches, and are active every day except extremely stormy ones. They can find a great deal of food, and therefore only bury nuts and acorns singly here and there in the fall, many of which they dig up even when hidden under a foot or two of snow. The red squirrel is also active all winter, yet has stored away, preparatory to this holiday, a vast number of nuts and such other provision as he likes in many secure places close to his nest, usually in some hole under the 
roots of a tree, or beneath a brush heap or pile of loose rocks. The same is true, in their ways, of the flying squirrels and of most of the wild mice; but though the chipmunk lays up an enormous store of nuts and other food in his tunnelled chamber deep underground, he comes out on warm days, now and then, to get a bite of fresh fare.

"The wild or native mice," writes John Burroughs, "lay up stores in the fall in the shape of various nuts, grain, and seeds, yet the provident instinct, as in the red squirrel and in the jay, seems only partly developed in them; instead of carrying these supplies home, they hide them in the nearest convenient place. I have known them to carry a pint or more of hickory-nuts and deposit them in a pair of boots standing in the chamber of an out-house. Near the chestnut-trees they will fill little pocketlike depressions in the ground with chestnuts; in a grain-field they carry the grain under stones; under some cover beneath cherry-trees they collect great numbers of cherry-pits. Hence, when cold weather comes, instead of staying at home like the chipmunk, they gad about hither and thither looking up their supplies. One may see their tracks on the snow everywhere in the fields and by the roadside. The advantage of this way of living is that it leads to activity, and probably to sociability. . . They link tree and 


\section{February 22}

stump, or rock and tree, by their pretty trails. They evidently travel for adventure and to hear the news, as well as for food. They know that the foxes and owls are about, and they keep pretty close to cover."

Lastly, there is a group of common little animals that avoid the ills and famine of winter by hibernation. Such are the bats in cares, hollow trees, and garrets; certain of the mice, like the jumping deer mouse; and especially the woodchuck or ground-hog, who retires to his grass-lined underground chamber early in the fall and rarely is seen until March.

There is, perhaps, no reason why a bird should not be able to pass the winter in dormancy as well as a mouse or a bat, but as a matter of fact none does, most of them migrating each autumn to the warmer South. Nevertheless, we in the colder parts of the country are not left without the companionship of these most delightful of our out-door friends, in regard to which I shall have an opportunity to speak again at the close of the year.

"Sunny hill-sides," as I wrote once, " the wooded banks of creeks, the hedgerows and brier-grown fences along the country roads, are all favorite places for the winter birds. Here come the sparrows and finches, the winter wren and rare cardinal, skulking about the thickets, hopping through the dead fern brakes, threading the mazy passages of the log 
heaps and brush piles ready to be burned in the spring, coming out upon the fence post or way-side trees to sing their morning roundelay and take their daily airing in pleasant weather. In the open meadows are the grass finches, snow-birds, and the few robins and med'larks that stay with us; in the edge of the woods the blue jay, flicker, and the butcher bird; in the orchards and evergreens the crossbills, the pine grosbeaks, red polls, and cedar bird; the deep woods shelter the tiny nuthatches, titmice, and the little woodpeckers; the open sky affords space for the birds of prey, and the sea-shore harbors for the gulls, sea ducks, and fishhawks. ... In very severe weather the wildest birds are often compelled to come close to the house and barn in search of out-door relief from gentle hands."

Towards the end of the month, however, the northward movement begins, in spite of the bad weather surely to follow, and during the last week the observer may note a decided increase of such avant couriers as the grakles, starlings, and robins, while the song sparrow is tuning up, and some of the hardy birds of prey are thinking of nest-building.

It is exceedingly fortunate that all the birds do not leave us in this month of outward desolation, for nothing so much as their cheerful presence in the February fields helps to keep alive in our hearts the sense of summer. 


\section{February 26}

\section{CALENDAR FOR FEBRUARY}

\section{MAMMALS}

Shrezes. - Active, but chiefly nocturnal.

Moles.-Active, but rarely seen.

Bats.-Occasional, when unusually mild.

Chipmunk. - Sometimes abroad on warm days.

Red Squirrel._Always active ; mating.

Gray Squirrel._-Awake and active ; mating.

Meadorv Mice. - Frequently abroad.

MIuskrats.-Occasionally abroad, near home.

Hares.-Common and active.

Deer.-Occasionally come out of the woods.

Gray Fox.-Common and bold.

Red Fox.-More rarely seen than the gray in the neighborhood of New lork.

Skunk.-Occasionally appears.

Weasels. -Numerous and bold.

Mink.-Uncommon and wandering.

Otter.-Active, but rare.

Black Bear.-Rarely cut of its clen; young born.

\section{BIRDS}

(General list same as in January)

Woodcock.-Arrives from South third week of the month.

Great Horned Owl.-Nesting last week.

Red-aingred Blackbird.-Arrives from South last week, the males first.

Meadow Lark. - Arrives from South last week; a few often remain all winter.

\section{February 27}


Purple Grakle.-Arrives from South second week.

Robins.-Becoming numerous.

\section{FISHES}

Pickerel.-To be caught through the ice.

Suckers.-Abundant, and now only edible.

Striped Bass.-Abundant in the Hudson.

Yellow Perch.-Common everywhere.

White Perch.-Abundant in the Hudson.

Black Bass.-Common in deep lakes and streams.

Tomcod.-Common in the Hudson.

Flat fish, or Winter Flounder.-Begins spawning. •

Many brook fishes.-To be taken in deep fresh waters.

\section{REPTILES AND BATRACHIANS}

All these are more or less torpid, and remain so, but some may be lured out for a few hours on very warm days. 


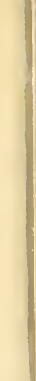




\section{A R CH}

"The bare hills glisten in the ascending sun, Whose rays compel the snow to hide In clefts and crevices, his power to shun." 


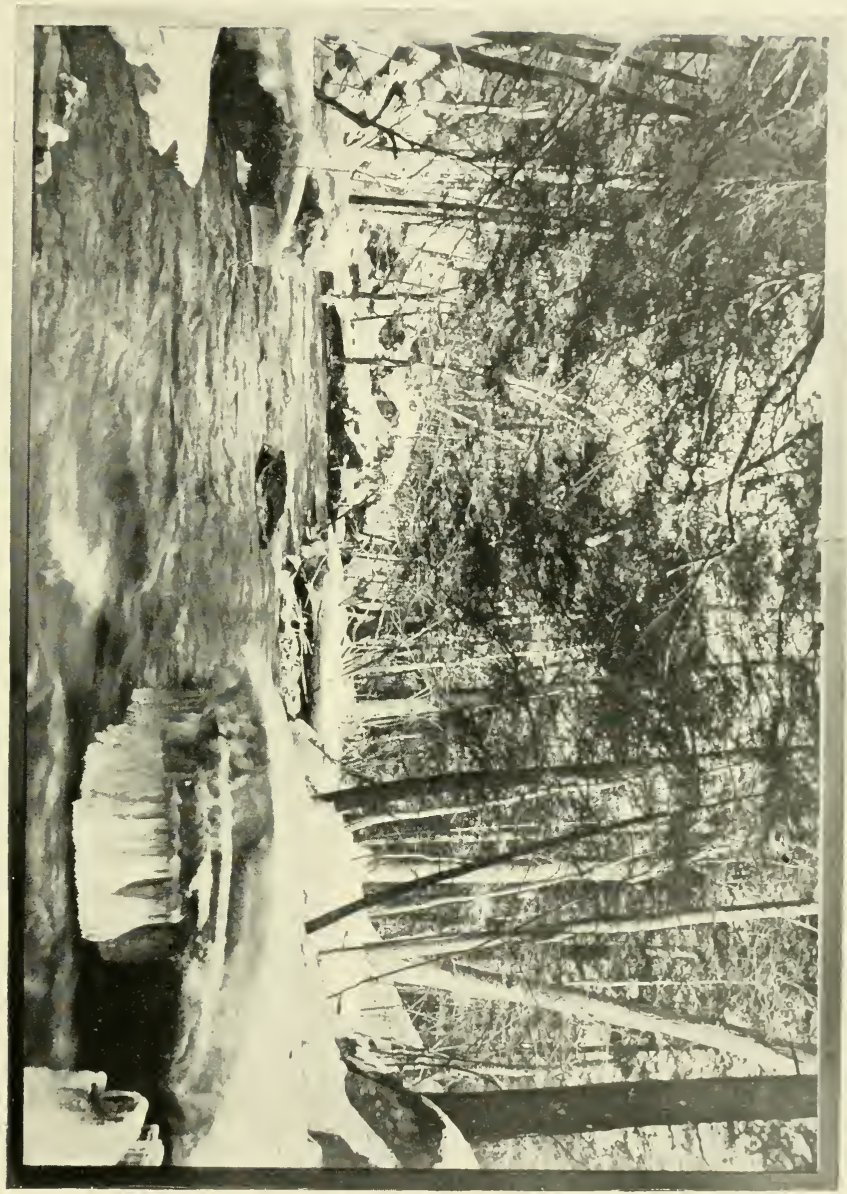




\section{MARCH}

MARCH now stands on our calendar as the first of the spring months, and in Great Britain, where the calendar was made, and whence we get our literary view of it, it really is so; but the North American climate is considerably behind that of England, and our March is usually sore wintry than spring-like. To the zoologist, even when March "comes in like a lamb," winter seems still in full force, and the coming forward of plant life is provokingly slow and uncertain. Neverthless its progress is sure, and pres$e^{r+l y}$ will quicken into rapidity of pace. Re ots are at work again, drawing sustenance into the stems of shrubs and trees and greenness into sprouting root-leaves, even under ice and snow. The sap wells up into the trees, and stimulates leaf packets and flower buds into a swelling growth that will enable them a little later to burst into a simultaneous and sudden development over the whole forest. Yet just when this begins, or how fast it proceeds, is hiclden from our eyes. "No mortal," remarks Thoreau, "is alert enough to be "resent at the first dawn of spring." B'tl the experienced observer notes the 
change in the appearance of the woods that denotes its coming long before winter relaxes its grasp. He sees a peculiar brightening of color in the contour-twigs of the groves and swamps, and by the middle of the month the ruddy hue of the leafless maple crowns is plain for half a mile. This reddishness is due less to the twigs, however, than to the blossoms which appear long before the leaves, as also do the blossoms of the aspen; and the bees hum about them for their earliest spring feast, save, perhaps, the sweets they have sucked from the skunk cabbage.

Now, too, is the time for " pussies," the drooping, fuzzy catkins of the willows, alders, and birches, which children love to gather; and by the close of the month, even in northern New England, the hazel

is covered with its minute but exquisite flowers.

Of lowlier plants those in and about the waters where the ice is disappearing show most verdancy-greenest and largest of all the skunk cabbage, which is scattered about the black ooze of half-flooded woods like so many great emeralds. The bees welcome it and get a good supply of the first of the season's sweetness in the pollen of its great flowers. But if one scrape away the matted dead leaves, or even the snow, one may find, early in the month, many little plants that have put forth their primary leaves, and will soon push out into the sunlight; and some of 
these speedily blossom into the first flowers of spring. Such are the liverwort or hepatica, and that most fragrant and exquisite of early blossoms, the trailing arbutus, or epigxa. These are soon followed by others, but north of the Delaware Valley one cannot hope to make much of a bouquet before April.

Until the cold diminishes and vegetation springs up, insect life cannot flourish largely, and hence fly-catching birds, and the many other creatures that depend upon insects for food, are not to be expected. Clouds of gnats and the waterbugs appear as soon as the ponds are open, skating about the placid surface in search of prey, and such hardy folk as the spiders and beetles wake up and begin to travel. "Very early in the spring," says Packard, "stones can be upturned, ants' nests searched, and the muddy waters sifted for species [of beetles] not met with at other times of the year." Even butterflies may be collected now-certain species of tortoise-shell (Vanessa) and angle-wing (Grapta).

The streams, relieved of their fetters of ice and swollen by melting snow and rain, widely overflow their banks and begin to teem with life recalled from deep waters or aroused from chambers in the mud. Hosts of small fishes ascend the streams, explore every tributary, and spread far and wide over the flooded meadows, finding an abundance of food and growing 
strong and fat; of these the eel-pout is perhaps the earliest migrant, appearing the instant the ice goes out. This is the time chosen by the smaller members of the pike family for spawning. "The pickerel," Mr. Mosher tells us, " are spring-spawners; hence boys see them just as soon as the ice has cleared out, the snow-water yone, and the warm days come. They are found in shoal water among weeds, or where the branches of trees are projecting from the shore into the water. Here they are found in pairs, gently swimming backward and forward in the stream, rubbing side by side until the female is ready to spawn. They are careless fish-leaving the spawn to take care of itself until the gentle undulations of the stream and the warmth of the sun's rays produce the young fry."

March is the month of frogs. All winter they have been silent and asleep in the earth or in frozen spring-holes, but the moment the ice disappears from the waters, and the early insects begin to hum, they arouse themselves and set about the great business of all naturethe continuation of their race. For this purpose all frogs - aquatic, wood, and tree, as also the toads-must resort to water in order to place their eggs where the young may grow properly when they are hatched.

Thronging to the marshes, ponds, and quiet streams, they break out some morn- 
ing with surprising suddenness into that croaking, rattling chorus of frog-talk that is the most characteristic noise of early spring. Among the earliest, often beginning in February, are the "peepers" or "tree-toads"-Pickering's and the common changeable one. Eggs of the former are laid and hatch within a few days, in masses of six or eight; but the latter breeds later. With their peeping is soon mingled the clamor of cricket-frogs, checkered leopard-frogs, the green springfrogs, then the twanging bellow of the bull-frogs, and at last the chorus is complete when the pretty wood-frog sets up its loud clucking towards the middle of the month when the sexes are meeting by the water. The female of the wood-frog is twice the size of the male, and deposits a mass of eggs as large as one's fist, from which tadpoles escape in about a week. An elaborate account of the breeding, hatching, and day-by-day development of this species, written by Miss Mary $\mathrm{H}$. Hinckley, may be found in the "Proceedings of the Boston Society of Natural History," Vol. XXII., Oct., I 882, pp. 85-95.

De Kay notes, in respect to the leopardfrogs, above referred to, that they are appropriately so called in Massachusetts. He says that in his day "from its simultaneous appearance with the shad it is frequently called the "shad frog" "; and he adds that the Swedish colonists of New Jersey " named them still hoppetos- 
ser, or 'herring-hoppers,' from their appearance at the commencement of the herring season." This popular observation was no more exact than that which named the shadbush or called the goldenwinged woodpecker "shad spirit."

During the last half of this first spring month you may gather varied tadpoles from every pool, which mature with more or less rapidity, according to the warmth they get. These tadpoles form a part of the food of many fishes, turtles, and even of the large predaceous water insects that are already abroad and active. The frogs themselves are preyed upon by various owls and hawks, especially by the slate-colored marsh hawk, which is one of the earliest arrivals (staying all winter in the Southern-Middle States), and later by snakes, mergansers, herons, and the like, and by such mammals as the skunk.

The toads and salamanders (except a few of the common green newts, which seem to breed all the year round) lay their eggs later. Most of the salamanders are awake before the end of the month in ordinary seasons.

Ask a farmer: "What is the earliest sign of spring?" and he will probably say: "The shedding of her coat by my old mare." Not only the horses, the cattle, and the family dog are putting off their winter overcoats of warmer fur, but wild animals do the same, as March advances; and in the North the animals whose coats

\section{March II}


have turned white now begin to resume their brown summer wear. The time when this change takes place depends upon the comparative lateness of the season, and upon latitude: in Canada and northern New England it will usually be postponed into mid-April. "It is surprising," remarks W. E. Cram, "how rapidly the ermine changes from white to brown after the process is once begun: one that I caught in a trap recently showed the transformation nearly complete, the back being of a peculiar shade of reddish buff with only one or two little spots of pure white fur, while the sides were thickly sprinkled with long white hairs, which were already detached from the skin and constantly shedding. The tail was divided into three distinct sections of color, black at the tip for about an inch, as in winter, then white for the same distance, and brown next the body. The white of the tail was confined to the long, coarse hairs overlying the soft under-fur, which was already brown. The feet were still white, like the under surface of the body and throat, which remain so throughout the season. - . The new brown fur must have grown out with great rapidity, for it was then about as long as it ever would be.

"In fact, I am not yet fully convinced that it was new fur, but rather the old under-fur of the last winter turned brown, and that only the long over-hair is shed 


\section{March I4}

in the spring. The more carefully I examined the fur of the specimen before me, the more I was persuaded that this was actually the case, and that the ermine habitually goes about with only its underfur on during the spring and summer, to give place to a new coat of short hair, which grows longer and is reinforced by thick under-fur in the autumn; while the whole turns white in November, through some inexplicable process which works alike with weasel and northern hare and ptarmigan, while the coats of other animals remain practically unchanged as far as color is concerned."

The rabbits skurrying about the rustling brush and sere meadows are not only thin but ragged, and, what is of more account, the pelts of the fur-bearers are no longer of much account to the trapper, because the minks and others of the more southerly woods have been so careless in squeezing through rocky rifts and mouseholes that they have worn and torn their coats very sadly. The breaking up of the ice lets the muskrat come out of his home and feed on shore, and the raccoon come down to the bank to get his favorite crayfish and mussels; he has young at this season in some hollow tree.

The barking of the red squirrel is heard again, and all its cousins cone out of their vermin - infested retreats and begin to build clean and cool nests of leaves, for family cares will soon overtake them. 
That admirable observer, the author of

Little Beasts of Field and IVood, gives us a pleasant seasonal note quotable just here:

"In March the red squirrels tap the maple-trees for their sap by gnawing through the bark on the upper sides of horizontal branches. The little cavities so made quickly fill to overflowing, and, stretched out at ease, the squirrels regale themselves to their satisfaction. . . . But their lives are far too busy to allow them to spend their entire time in this manner, and during their absence the sap is apt to form into icicles, which, when the temperature of the wind and other conditions are favorable, may be constantly evaporating and gathering new material at the same time, so that the sugar contained in the sap finally collects in rich, honey-colored drops of syrup at the extremity of the icicle, possessing an even more refined and delicious flavor than that obtained by the more violent process of boiling. The squirrels appear perfectly capable of appreciating this fact, and are pretty certain to be on hand to gather it before it drops, although often obliged to exert themselves to the utmost to reach it."

That old sleeper, the woodchuck, is recalled to life and staggers sleepily to the mouth of his burrow to see how the world gets on. Once awake, he stays out, regardless of any bad weather to follow-and it 
usualiy does follow in the northern parts of his range, where, however, he rarely appears before mid-April.

The hibernating chipmunks and fieldmice-already nourishing young in balllike nests of grass, fuzz, and fur under the tussocks and old haycocks - are more discreet, going back to their dens and storehouses when the weather is too severe, to doze again until another warm spell invites them forth. Hibernation is thus gradually thrown off, as it was gradually entered upon. I have read that Canadian Indians named March "skunk moon," because now this unsavory mammal begins to be seen regularly.

Few of the reptiles emerge from their torpor before the end of the month in the more northerly districts, one of the earliest being the painted water-turtle, quickly followed by the speckled tortoise along swampy streams.

Winter birds remain characteristic of the first half of March, but the trained ear notes a greater liveliness in their movements, and some attempts at a song, as though they were become eager at the prospect of soon getting back to their Canadian summer resorts. Two or three species, indeed, are already there, and busy at nest-building, but these are unfamiliar ones, like the big owls and the crossbills. Among us near New York, however, the barred owl is the only one to breed so early, regularly making its rude 
nest in the top of some forest-tree about the middle of the month, where frequently the sitting bird is half smothered in snow.

By the 15 th the earlier water-fowl are passing northward and summer friends begin to reappear. Sportsmen know that as fast as the ice leaves the lakes and rivers flocks of ducks and geese will drop down from the sky upon them at evening, and they go after them in the chilly gray of these mornings, when water-fowl feed preparatory to taking a farther flight; and as the frost and freshets leave the lowlands other sportsmen tramp thither in search of early snipe and plovers.

The characteristic birds of March, however, are the blackbirds and sparrows, with here and there a robin, wren, pewee, and the always welcome, ever lovely bluebird. "As with tinkling sounds the sources of the streams burst forth their icy fetters, so the rills of music begin to flow and swell the general choir of spring." The cheery cong-ker-eeé of the redwing come from swamp and river bank on clear, warm mornings, when the air is balmy with the breath of the south wind and the smell of the new earth, and a thousand still pools in the meadows reflect the clear blue sky-mirrors that the sun will soon dry away; and from every thicket along the edges of the leafless but budding woods comes the re- 
joicing roundelay of the song sparrow. As I have written elsewhere:

"He starts off with a few rattling notes, makes a quick leap to a high strain, ascends through many a melodious variation to the key-note, and suddenly stops, leaving his song to sing itself through in your brain. To amplify another's illustration, it is as though he said 'press-press-PRESS-BY-TEEEE-RIANian!' His clear tenor, the gurgling, bubbling alto of the blackbirds, the slender purity of the bluebird's soprano, and the solid basso profundo of the frogs, with the accompaniment of the April wind piping on the bare reeds of winter, or the drumming of raindrops, form the naturalist's spring quartette-as pleasing, if not as grand, as the full chorus of leafy June."

Goldfinches, too, are here, but not yet in their gay plumage, nor animated into song. Slate-colored snow-birds dart hither and yon, chirping in metallic syllables. In all the open meadows, when the new grass is shooting its green spears up through the matted and sere foggage, are tlitting the miscalled "tree" sparrows, and the vesper sparrows, the latter flirting their white-tipped tails and carolling sweetly in the dusk, where meadow-larks are loudly calling. The thickets harbor restless bands of white-throated sparrows, called Peabody birds in New England, in imitation of their lively melody: and among them you will meet, more 
rarely, a cousin, the white-crowned, whose cheery cry is prai-rié, re-re-reé.

But the prize of this group is the large and uncommon fox sparrow, whose song is a rich, modulated whistle, finer, more cultivated than that of any other sparrow, and a treat to the ear among the cheery but less musical jingles of the other finches. Another very beautiful song, sometimes begun amid the uncertainties of March, is that of the purple finch, but none equals that of the fox sparrow-not even the wonderfully loud yet musical fluting of the winter wren.

Very characteristic of these early days of reviving nature, also, is the sonorous drumming of the small woodpeckers on some dry and resonant limb-a distinctly musical performance. It is usually the downy, but, as Mr. Burroughs says, "he is not rapping at the door of a grub; he is rapping at the door of spring." It is a method of amusement and expression and of advertisement for a mate.

Formerly in the East, and still to some extent in the middle West, long sinuous lines of wild pigeons were wont to sweep across the gray March skies-an inspiring sight. This bird, once so characteristic of the month, is almost extinct; but there arrives in our latitude about the middle of the month its cousin, the Carolina or mourning dove, a bird so gentle and apparently delicate that it is a surprise to see it in this bleak weather, and 


\section{March 26}

its plaintive note at evening seems to express the deepest regret at having left so soon the sunny South, where its winter was passed.

Few birds settle down to house cares so early as this month north of Virginia and the Ohia Valley. The crow may sometimes do so, and a few robins and bluebirds are so eager to begin housekeeping that they will not wait for a better season, but they often come to grief in consequence, especially the phobe-bird,which frequently pays for her haste and temerity by freezing and starvation. 


\section{CALENDAR FOR MARCH}

\section{MAMMALS}

Hibernating species reappear.

Little Brown Bat. - First one out, first week.

Gray Squirrels.-Building tree nests; first litters sometimes produced.

Red Squirrels. - Preparing new tree-built nests for first litter of young ; regaling themselves on maple sap.

Weasels.-Begin to turn from white to brown, earlier or later, according to circumstances, and to seek mates.

lrinks.-Seeking mates; coats much faded and worn.

Bears. - Young able to follow their mothers. Kaccoons.-Young born late this month.

Deer. - Shedding their coats and losing antlers.

\section{BIRDS}

Sheldrakes.-Passing North last week.

Mallards.-Passing North last week.

Pintuil or Sprigtail Ducks. - Passing North last fortnight.

Wood Duck.-Arrives from South last week.

Scoter Ducks. - Depart northward.

Ruddy Ducks. - Passing North last fortnight.

Canada Geese.-Passing northward.

Sinipes-Pass northward.

Some bay-birds pass northward.

Mouming Dove.-Arrives from South second week.

Marsh Hawk. - Arrives from South first week.

Rongh-legged Hawk.-Passing northward.

Barred Owl.-Nesting, second week.

Phabe-bird.-Arrives from South second week ; sometimes begins nesting. 


\section{March 30}

Cozu-bird.-Arrives from South third week. Red-winged Blackbirds. - Arrive from South third week, the males a few days in advance of the females.

Rusty Blackbird.-Arrives from South third week; appears in pairs, not flocks.

Puple Grakle. - Advance flocks arrive in early seasons.

Purple Finch. - Winter residents begin singing.

Fox Spamow.-Arrives from South second week.

Song Sparrows.-Become noticeable and begin singing.

Bluebirds.-Become numerous and begin singing, and sometimes nesting.

Many winter birds linger through the month.

\section{BATRACHIANS AND REPTILES}

Salamanders. - Occasionally seen about springs.

Frogs, - All kinds seeking water and deponiting eggs ; the tree frogs, or peepers, earliest and the wood-frogs latest

Snakes.-Rare; a few come out on warm days towards the last and bask in the sun; some kinds are mating.

Turtles and \%ortoises. - Awake, the aquatic species appearing earlier than the terrestrial ones; and some are mating in southerly localities.

\section{FISHES}

(See Calendars for February and April)

Pickerel._-Spawning in grassy shallows.

\section{INSECTS}

(See January and April Calendars) 


\section{A PR I L}

"The south wind's balm is in the air, The melting snow-wreaths everywhere Are leaping off in showers." 


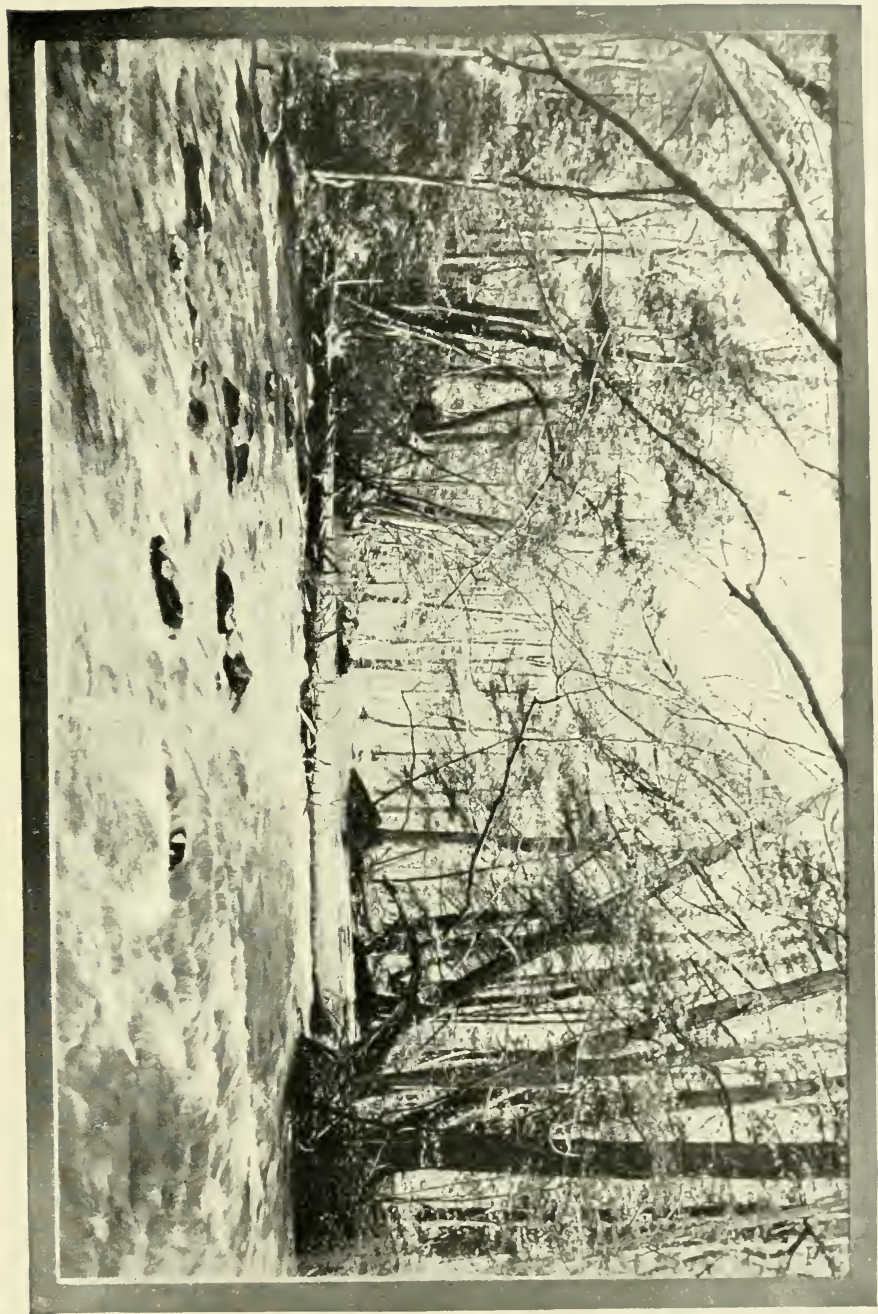





\section{APRIL}

APRIL is the child of March rather than the father of May. Its weather is as uncertain as the origin and meaning of its name, but it is pretty sure to be wet and chilly in northerly latitudes, however delightful it may be in the "sunny South," where one nay "lean his cheek against the air as if it were velvet," as has been said. Now and then a balmy fragrant day of that sort soothes and delights us, even in bleak New England, whose snowdrifts are not yet wholly melted, and these days exert a wonderful growing influence upon the plants. April is the month of unfolding leaves, which swell with the sap now pumped up energetically from the frost-free earth, moist with spring rains, and the woods take on a singular and evanescent beauty, assuming a misty, gauze-like robe of the most delicate green and pale red, formed by the starting foliage. The end of the month has come before the forests are fully leaved, even as far south as the Potomac.

Under foot, meanwhile, the herbage is springing, green and tender, among the drifted leaves, whose substance has sunk 
into the soil with the rains for their nourishment, and the farmer's cattle and nature's more timid grazers are feeding with content and joy on every meadow and hill-side; and day by day we find in the woods more and more of those sweetest of the botanist's treasures, the early wild flowers of spring. Their first leaves, rolled into a close cone (the adder's tongue is a good example), easily push through the moistened soil, and in a breath of the south wind, as it were, they suddenly burst into bloom.

It is interesting to note that April's flowers are usually frail, certain species which later grow tall and stout blooming at this early season close to the ground. White, or white flushed with pink, or honey-color deepening in some flowers into buttercup-yellow, as in marsh marigold, seem to be the prevailing colors now. It is as if the plants had been differently affected by their waiting under the snow-some bleached and others yellowed.

A few violets, blooming cautiously near the end of the month, bring in a new color tone; the vivid green, purple, and crimson of the skunk cabbage remain as a relic of March; while the great redpurple, evil-smelling triangles of the purple trillium make jarring notes in this color scheme. The trailing arbutus, well fortified by its woody structure to withstand the snow, opens its chalices of per- 
fume, ranging through the tints of shellpink, before the ground has yet dried in the shelter of the hemlock woods. The saxifrage sends up its little tufts of tiny flowers, purely white on the cliffs, crowding the wonderfully feathery, fern-like leaves of the Dutchman's breeches, whose rows of comically shaped but dainty, yellow-tipped white blossoms are now hanging from bending stalks. At the base of the rocks, if the ground be sufficiently rich, stand the white flowers of the bloodroot, which are not only inwrapped, as buds, in a folded leaf, but even take the precaution of folding up their glossywhite petals at night. This wise precaution against the chilly night is also adopted by the pale-blue. pink, and albino flowers of the liver-leaf (Hepatica), perhaps also by the cross-shaped blossoms of the cruciferx that bloom at this season, by the delicate flushed bells of the anemone, and by the pert, thin petals of the rue anemone. The perishable, pinkstriped flowers of the spring beauty certainly shrink again into the semblance of buds when the evening shadows fall upon them.

What is more brilliantly white in April than the showy domes of the shad-bush (noting the coming of the welcome fish) that dot the hill-slopes with as brave a show of high lights as even the dogwoods can furnish? Behind it, on northern hill-sides, flourish large bushes of 
fly honeysuckle, covered with pale green leaves, the slender branches tipped with pairs of honey-colored bells.

In the swamp yellow prevails. There one finds the marsh marigold, growing fairly in the water; the leatherwood, with little yellow pairs of flowers; and the golden knots of bloom threaded along the olive-colored branches of the spicebush: while wide spaces of marshy land are gilded by the hanging lilies of the adder's tongue.

The coming of plentiful sunshine and soft airs brings out of retirement, and hatches from eggs safely laid away last fall, a large number of "small and early" insects, whose humming fills the blossomcovered maples, basswoods, and other honey-laden trees; also bark-borers, beetles, and other hardy forms that live on tree-trunks or on or near the ground; ants and worms are throwing up their hillocks everywhere; a sprinkling of moths and butterflies appears; and in chase of all these go industrious parasites, such as the ichneumons.

Among the moths and butterflies small, dull-colored forms prevail-the advanceguard of the brilliant hosts of midsummer. Such are the little, gray, nightflying moths; several species of tortricids, mostly those whose young prey upon fruit, such as the apple worm; these must, therefore, be on hand to deposit their eggs in the fruit buds. Tineids are 
to be seen, too-the family to which the clothes moth belongs-and it is now that these and other household pests begin to lay their eggs. The common, blackstreaked brown butterflies ( $V$ anessa) are more or less about, and towards the latter part of the month we begin to see several other small, low-flying, and usually blue butterflies, chiefly elfins (Lycana) and orange-tips (Euchloë).

With these appear the coddling moth, and those swift, pretty flies (Bombylius) whose " eggs are laid in the nests of bees, where the half - cylindrical, long, fleshy, smooth, unarmed larvæ devour the bee larvæ." The peach-spoiling beetle (Euromyia) is now feeding on sap, and presently will be flying about the fields and woods, where, as the month closes, mosquitoes and gnats begin to be troublesome and the dragon-flies are coming to feed upon them.

In and about the water insect and crustacean life is well advanced-prettiest of all the glass-like, fairy shrimps-so that the fishes and turtles, that have been on short commons, are eagerly enjoying a feast, getting fat and brisk, and beginning to discharge the duty of egg-laying, so that the young may be hatched and get a fair start for growth during the summer. Hence, in every stream and lake and bit of inland water the domestic life of the fishes begins now, as does that of the birds of the air. 
None is a better type of the brook fishes than the perch, the handsome, gold-colored, darkly barred type of all the bony fishes. You will find him wherever there are quiet waters of moderate depth, loitering in pools under hollow banks, poising in eddies and shady reaches, preferring the sides of the stream to its swifter central currents, and liking a sandy or pebbly bottom better than a muddy one. If you try to catch perch in a mill-pond, you must drop your line in the deepest water. You will have the best chance alongside some bridge-pier or sluice-gate.

"When the marsh marigold blooms in the meadows, the spawning-time of the perch is near at hand." This means our month in the middle districts. The perch's eggs are about as large as poppy seeds, and cling stickily togrether "like pearl necklaces, in beautifully interlaced bands," five or six feet long and an inch or two wide. These glutinous ribbons adhere to twigs and stones in shallow water, and are sought for as dainties by birds, by fishes, and by all kinds of aquatic animals, so that few out of the many survive. It is because the dangers to which the eggs and young are exposed are so many and persistent that these creatures are obliged to lay tens of thousands of eggs apiece, in order that one or two alone may have a chance of surviving to maturity. Nowhere is the struggle 
for life more fierce, the slaughter more prodigious, than among the inhabitants of the waters of the earth.

Some brook fishes, however, lay larger and fewer eggs because they are able to care for them to a considerable extent. Such is the case with the sunfishes, the commonest example of which is the pumpkin-seed, beloved of all young anglers and some old ones. These are most brilliant of hue and at their best now ; and it is now, too, that they are most easily caught, for all are near shore, laying their eggs or guarding them. For this they prefer still, clear water, and during this month, in the more southerly parts of the country (but not until summer in New York State) the female sunfish prepares herself a circular nest by removing all twigs, dead plants, and so forth, from a spot on the bottom as big as a dinner-plate, where she digs away the sand and gravel to a depth of three or four inches. In this clean hollow she deposits her spawn. "It is curious," wrote Dr. Kirtland, long ago, "to see how she guards the nest against all intruders, seeing in every fish, even those of her own species, only an enemy, and becoming restless and uneasy until she has driven it away from her nursery. We often find groups of these nests placed near each other along the margin of the pond or river, but always in very shallow water. . . They are frequently encircled 
by aquatic plants, which form a curtain round them, leaving open a large space for light."

All of these perch-like fishes, from the big pike-perches of Western rivers to the little "breams," are fierce and voracious. Not content to feed upon the worms, grubs, insects, and snails that abound in their waters, they greedily devour the eggs and young of other fishes whenever they can find them, even of those of their own kind; and they prey like bandits upon the smaller sorts, making an openmouthed dash into a flock of minnows, and trusting to luck to catch one, rather than chasing them down. Between these and the bass, the pickerel, and a dozen other larger sorts, the life of the minnow is a constant dodging and fleeing; and it is no wonder they have become so nimble that we call them "darters," for it is only by nimbleness and speed, suspicious watchfulness and ability to dive out of sight into the mud, that they can live from day to day.

"Minnow" is rather an indefinite term in America, for here it means almost any small fish which, from the angler's point of view, is good for nothing but bait; but some minnows grow to be of considerable size, as dace or roach or gudgeons. One of the local amusements of the Baltimore people, in April, is to go to the Patapsco River, near the Relay House, and fish for gudgeons with the 
finest sort of tackle; they say it is capital fun.

The males of many of these small fishes develop special colors and appendages this month, indicative of the breedingseason, and lasting several weeks. Thus male chubs become rosy, and sometimes horny spines appear on their heads, whence the name horned dace, by which they are frequently known. Other minnows are gorgeous during April and May.

Another sort of fish that protects its nest is the bass, a name that includes a great variety of fishes, some of which ought not to be so called. But the two sorts of black bass, and the rock or striped bass, are true ones, and among the finest. They do not begin to spawn in northern rivers until later, but in warm southern rivers they are now making nests by fanning away the surface mud with their fins until a clean, bowl-like receptacle is formed, where the spawn is deposited and then is jealously guarded. For this purpose a gravelly spot is chosen, from which the slimy surface is removed, that the eggs may have clean pebbles to stick to, and thus not be drifted away with the current. They hatch in eight or ten days, during which time the female poises herself above them and protects them to the best of her ability.

These and the striped bass of southern estuaries are themselves, however, no respecters of the rights of others. They 
play havoc with everything not able to defend itself, and gorge themselves on the small fry. Similar in habits at this season are the white and the yellow bass of the interior waters, and also the fine little white perch of the southern tidal estuaries, which in these vigorous spring days follows and greedily feeds upon the hordes of young eels that now throng at the foot of every rapid or dam obstructing their passage up the streanss.

Another set of fishes destructive at this season-ogres of dreadful mien to the shiners and killifishes, and even to larger folk of the river-bed-are the catfishes. They abound in all the fresh waters of the country east of the Rocky Mountains, and are easily classified at a glance by their blackish, leathery skins, big heads, ravenous mouths, and ugly barbels. Some of them, in sluggish southern rivers, reach a weight of one hundred and fifty pounds, but most of the species are small. All these siluroid fishes, from the little bull-head to the huge channel cat, are voracious feeders, and not at all nice in their tastes, greedily devouring any animal substance, living or dead, that they can seize, and frequenting the foulest water as well as streams that are sweet and clear. They keep close to the bcttom, and deposit their spawn in the early spring. A far nobler spring breeder is the handsome, agile, blood-thirsty pickerel.

These are entertaining episodes in 
brook and pond life, but in the larger streams a still more interesting series of facts is taking place cluring these mid. spring days, in the coming of the migratory fishes from the sea. The most prominent example all along our northern coast used to be the lordly salmon-and even yet April sees a few of them entering the clear rivers of Maine, climbing the rapids and leaping the cataracts as of yore in eager haste to reach their autumnal breeding-places at the forest-hidden sources of the stream. Some are now seen annually in the Hudson.

Other anadromous fishes - as these are called which annually resort from the sea to fresh waters-remain to us, and it is still a matter of livelihood and enjoyment to many people that every spring the herrings, alewives, the shad, and many others crowd into our watercourses from the ocean.

Much mystery still belongs to this regular migratory movement of these fishes. We can trace them in the rivers, know when they arrive and when they depart; but where the winter is spent, and how they are moved to return each spring to the fresh water, are little understood. Nearly all these fishes appear first in the extreme south, entering Florida rivers long before the northern ones are free from ice, and gradually occupying the latter as they become open and sufficiertly warm. Temperdture seems 
to be the principal consideration, and each kind of fish seems to have its own ideas of what is right in this respect. It appears as though the oceanic fishes, like the birds, come up the coast as the season advances, and to some extent this is true; but it is believed that for the most part they retreat straight off the coast to deep water in the fall, and return in the spring from wanderings, the extent and depth of which we have no means of knowing. It seems sure that the fishes bred in certain streams return to that very stream the next spring, and year by year afterwards as long as they live; and this habit is far more mysterious than anything in the migration of birds. The probability is that they do not go very far away from shore.

By the ist of April good sea-fishing has begun along the southern coasts, and by the end of the month it is at hand farther north. The surf whiting, or tomcod, may be caught in the Carolina surf, and sheepshead are plentiful in the harbors. Redfish are swimming lazily about the southern sounds and bayous in search of food, or are sunning themselves in the shallows. The Spanish mackerel are already breeding among the Sea Islands, where the cotton grows. The menhaden are playing along the surface of the sea off the Virginia capes, and will soon start the New Jersey and Long Island fishermen at manning their seine-boats. Tautog 
are to be caught now, the earliest of the sea-fishes to arrive from deep water, except, perhaps, the lampreys, which are ascending the river to spawn among the pebbles, with which they form a sort of nest. Herring are thronging all along the coast,

"And alewives, with their crowded shoals, in every creek do swim,"

as a quaint old poem describes it.

Alewives are an inferior sort of shad, and the earliest of the sea-fishes to ascend the Atlantic rivers in any great numbers. The time varies with the lateness or earliness of the season and the consequent variation in the temperature of the water. Their eggs are adhesive, like those of the herring, and stick to the bottom in shoal water, or to anything they may touch, from sixty thousand to one hundred thousand being laid by each female fish at once, almost all of which are devoured by countless enemies before any can hatch.

Later come the hosts of that most important of all our eastern anadromous fishes-the shad. They appear in the St. John's River, in Florida, in November, and spawn in March. In the Savannah River they appear in January, in Albemarle Sound a few days later, and in the Chesapeake Bay in February, where, in April and May, the fishing is at its height, 
while the Delaware and Hudson rivers see them nearly as soon, or whenever the water reaches the temperature of sixty or seventy degrees Fahrenheit. They go as high up the river and its tributaries as possible, and spawn in the shallow water near the sources. In the Hudson shadfishing opens about the Ist of April.

None of these fishes seem to feed in the fresh waters at all, spending their whole time and energy in frantic haste to reach their spawning-grounds and finish their errands. Then, poor and weak, they turn back, but only a few arlult fish ever seem to regain the sea, though the catch of "back shad" in the Hudson is considerable. The race is maintained by the escape of the half-grown ones, and by the return in the autumn of the young which are hatched during the summer and at once begin their perilous journey to the ocean.

Lesser marine life is also waking up and attending to the first great duty of nature - propagation. Now the eggs of the common edible mussel are hatched, and the young are attaching themselves to rocks, algæ, etc., in the tideways at the mouths of streams and harbors; the naked Eölis is gluing its eggs to seaweeds, and on the sandy beaches the big pear-shaped "winkle-shells" are beginning to spawn. Within the sands various tube-inhabiting worms, or annelids, especially the common Vereis are reproduc- 
ing their kind, in which duty vast numbers of males desert their burrows and go swimming about on the surface of the sea. The crabs and other crustaceans are becoming active in the same effort, and now lobsters approach the shore from deeper water in order to spawn, and the lobster-fishing for market opens.

This is the breeding-season of some of the earlier manmals-especially the furbearers. The skunk increases its burrowkept family, the raccoon brings forth, in her lofty chamber in some hollow tree, from four to six baby 'coons early in the month, and the flying squirrel now introduces its kittens to the world. "Flying squirrels," says Dr. Merriam, " make their nests in hollows of trees, frequently taking possession of old woodpeckers' holes. They are easily aroused and driven out by hammering against the trunk. I have thus expelled the occupants of as many as half a dozen nests in a single day's hunt. Their progeny must be brought forth early in April, for on the 3 th of April, s 878, Dr. C. L. Bagg and myself took three half-grown young from a woodpecker's hole, about fifteen feet above the ground, in a decayed stub."

The young of the red squirrel also are born early in this month; and now, too, appears a new supply of one of their enemies - the marten, which produces this month a litter of half a dozen in a nest in some hollow tree or log. Its 
relative, the common mink, is similarly rejoicing in an addition of four or more to its family, hidden in some den among rocks or beneath the roots of a half-dead tree; and for both of these an ample provision of young field-mice is at hand.

The otter-now alas! rare within the Eastern States-was also wont to breed in the early spring. "The nest of the otter," we are told by Merriam, " is generally placed under some shelving bank or uprooted tree, and has been found in a hollow stub. Her young are commonly brought forth about the middle of April, and two (rarely one or three) constitute a litter."

In a similar place young gray foxes see the light-perhaps earlier in the Southern States, to which this species is now mainly confined; and the kittens of the bay lynx are mewing in their warm nest beneath some fallen tree or protecting slab of rock far in the forest.

The coats of all the fur-bearers are now ragged and worthless, for molting has begun, and the under-fur is beginning to come out. The females of most of them are in retirement, for the young of the larger part of the smaller mammals of the northwestern part of the country are born in April or May. The game animals are coming out of the deep woods, and seeking open places, or climbing high up in the hills, for the flies are beginning to be troublesome, and, more- 
over, they are in need of richer pasturage

than they have been having. The deer resort to ponds to feed on succulent aquatic plants.

As for the birds, those who are interested in their nesting must now keep sharply on the lookout, as well as those who wish to greet all the migrants as fast as they come from the South. The lateness or earliness of the season affects both these aspects of bird life; but arrivals are constant, and the earlier comers are housekeeping before the month expires.

Many ducks pass northward in the earlier part of April, and the winter ducks catch the infection and depart with them, as also do some bay-birds. Their place on the coast and in the marshes is taken by the arrival from the South of resident coots, rails, and members of the heron tribe, which come during the first fortnight. The first week usually brings to us the kingfisher, some small sparrows, white-bellied swallows, the house-wren (a little before the departure of the winter wren), and a few others.

These are closely followed by the seaside and some other sparrows on the heels of the northward-bound fox sparrows, and by the purple martins, bank swallows, brown thrashers, and the earliest warblers, like the blackburnian. The third week brings still more-whippoorwills, chimney swifts, chewinks, barn swa!- 
lows, catbirds, and more warblers, including familiar ones, such as the oven-bird and Maryland yellow-throat.

The last days of April begin to be crowded with strangers from the South, yet show us the most lingering of our winter friends, reluctant to leave us for their northern breeding-grounds. We are likely before May-day to add to the list the humming-bird, kingbird and his small cousin, the chebec; the eaveswallow, red-eyed, white-eyed, and other vireos, the black-throated blue, yellowrumped and palm warblers, and those glorious singers, the wood-thrush and the veery.

Fewer birds are nesting than will be found in May, but nests of the eagles and of duck-hawks may be had early in the month, if they are to be had at all; and other very early nesters in April are the three small owls and the crow, whose eggs may usually be found before the I 5 th. By that time, or a little later, also, the robin, bluebird, chickadee, purple grakle, and broad-winged hawks are laying eggs.

Meanwhile other birds are arriving joyously at their summer home, and displaying themselves to each other, with matrimony in view, singing loudly in rivalry and out of pure delight of existence, so that the summer of bird life is well ushered in by the time the month draws to its close. 
As usually happens the restoration of bird life to the land and the prospect of eggs and fledglings is accompanied by the revival of their principal enemy the serpent. April sees all the snakes come forth, except, perhaps, the rattlesnakes and copperheads; and seeking the sunniest and snoothest places they are now constantly encountered in the roads and paths, or coiled up on warm stone walls.

The salamanders are all out before the cnd of the month, and several are making their way to the water to breed. They are to be found in the forests under stones and logs, or amid decaying stumps. The little vermilion red newt abounds everywhere in the woods (though rather rare in northeastern New Jersey), appearing in thousands after warm rains. This is a youthful terrestrial form of the common green newt of ponds, which becomes large and green when it takes to the water when about three years old. "This salamander, according to the observations of Professors Gage and Cope, lays its eggs [seemingly all the year round] singly in the leaves of plants or on stones. The larvæ are more or less of the iridescent color of the adult, and . . . most of them lose their gills and leave the water at the end of the first season, to gradually assume the terrestrial form with its distinctive red coloration. This stage is believed to continue "until the autumn of the third or spring of the fourth year 
after hatching, when they assume adult form with its iridescent coloration, generally entering the water."-(Sherwood. Proc. Linn. Soc. of N. Y., I 895 .) The eggs of this newt number eight or ten and are laid separately, in the course of about four days, each in an adhesive envelope which sticks firmly between the folded edges of a leaf or between two leaves of some water-plant, which are pinched together between the hind legs of the female as she labors to extrude the egg. This happens only in warm springfed ponds so early as this, the newts in the colder waters of lakes deferring the oviposition until June or later.

Some other salamanders are breeding at this season, when eggs of both the marbled and the spotted salamanders may be got in swamp-pools and still ponds. and the parents remain near by. The spawning habits and larval growth of the latter are a fair type of the group (.tmbly'stoma). Her eggs are hollow spheres, about a quarter of an inch in diameter, embedded or combined in a large mass of perfectly transparent jelly. Within each sphere is a dark yolk, which in the course of some days becomes considerably elongated, and exhibits signs of animation which in a few days result in the birth of a young salamander, which struggles out of the egg-envelope. "At this time," says Cope, "it is about half an inch in length, and consists simply of head, body, and tail, 
the latter with a well-developed fin extending from the head and arms to the extremity of the body. Respiration is performed by means of three gills projecting from each side of the neck, of very simple construction, however, and with but few branches.

"The absence of limbs is compensated by the existence of a club-shaped appendage on each side of the head, proceeding from the angle of the mouth, and representing the cirri observed in some adult salamanders. By means of these appendages the young salamanders are enabled to anchor themselves securely to objects in the water. In the course of a few days a tubercle is seen to form on each side, just behind the head and under the gills, which elongates and finally forks at each end, first into two, then three, and at last into four branches, thus exhibiting the anterior extremities, with the four fingers, which latter, in the larva, are very long. Before the fore-legs become completely formed, those behind sprout out in a similar manner, with first three, then four, and finally five toes. During this time the gills have increased in the number of branches, and finally exhibit a beautiful arborescent appearance, in which the circulation of the blood can be distinctly seen by means of a simple lens."

Turtles are later in their time of breeding, hut the fresh-water turtles are mating. 
The land snails revive with the warmth of the spring sun, and become noticeable this month in accordance with the weather. During these early days they sometimes assemble in considerable numbers in warm and sunny situations, where they pass hours in indolent enjoyment of the warmth and animating influence of the sunshine. "Whether these meetings serve any useful purpose in the economy of the animal, or are caused by the pleasurable sensation," Mr. W. G. Binney, the principal authority on this subject, " is uncertain; it is probable, however, that they precede the business of procreation. It is certain that they last but a short time, and that, after early spring, the animals are to be found in their usual retreats."

"April," writes the author of Signs and Seasons, "is the time to go budding. A swelling bud is food for the fancy, and often food for the eye. Some buds begin to glow as they begin to swell. The bud scales change color and become a delicate rose-pink. I note this especially in the European maple. The bud scales flush as if the effort to "keep in "brought the blood into their faces. The scales of the willow do not flush, but shine like ebony, and each one presses like a hand on the catkin that will escape from beneath it." 


\title{
CALENDAR FOR APRIL
}

\author{
MAMMALS
}

Meadow-mice. - Producing young of first brood in nests on the ground.

White-footed Mrouse.-Young born in bush nests often constructed in an old bird's nest.

ked-backed IVoud-mouse. - First litter of young in a nest in the ground or under a log.

Squirrels of all sorts. - Beginning to produce young, commonly in leafy nests among tree branches.

Deer.-Bucks separating from the band.

IVild-cats (lynx). - Producing young in grounddens.

Gray Fox. - Three to five young born.

Martens, Minks, and Weasels.-I'roducing young irregularly.

Skunks. - Producing young in burrows.

Otters.-Producing young in holes in stream banks, or sometimes in hollow stumps, etc.

Fur-bearing mammals shedding winter coats.

\section{BIRDS}

Shcletrakes. - T'ass northward.

Wullards._-Pass northward.

Teals. - Pass northward.

Pintail Ducks. - Pass North first week.

Redhead Ducks. - Pass North first fortnight. Broad-bill, or Scamp Ducks.-Pass North first fortnight.

Golden-eye, or Whistler Ducks.-Arrive and pass northward.

Buffle-heads.-Arrive and pass northward. 
Old Squaw Ducks, -Depart northward.

Bitterns. - Arrive from South second week. Great Blue Herons. - Pass North second and third weeks.

Little Green Herons.-Arrive from South third week.

Night Herons. -Arrive from South second week.

Clapper Rails.-Arrive from South.

Virginia Rails. - Arrive from South.

Coots and Bay'birds. - Pass northward.

Eagles.-Nesting irregularly, on cliffs and trees.

Duck-hawk.-Nests first week, on cliffs.

Broal-iving.-Nests third week; trees.

Pigeon Hawks. - Pass northward.

Longered Owul.-Nests second week; holes. Sazu-whet Owl._-Nests first week; tree holes.

Screech Owl.-Nests first week; tree hole:

Kingfishers.-Arrive from South first week. Safsuckers. - Pass northward.

Whitpoorwills.-Arrive from Sonth third week

Chimney-sivifts. - Arrive from South third week.

Ifumming-birts. - Arrive from South fourth week.

Kingtirds. - Arrive from South fourth week. Chebec. - Arrives from South fourth week.

Crowe.-Nests second week; tall trees.

Rusty Blickbirds. - Pass northward.

Purple Grakle.-Nests fourth week.

Vesper Sparrowis. - Arrive first week.

Savanna Sparroaus. - Arrive first week.

Yellow-winged, or Grasshopper Sparrow's Arrive second week.

Sea-side Sparrows. - Arrive second week. 
Tree Sparrow's.-Depart North third week. Chipping Sparrous. - Arrive from South first week.

Field Sparrow's.-Arrive from South first week.

Snow-birds (Junco).-Depart North fourth week.

Swamp Sparrows. - Arrive first week.

Fox Sparrou's.-Depart North second week. Chezvinks, or Towhees. - Arrive third week.

Purple Martins. - Arrive from South second week.

Eave, or Cliff Swallows.-Arrive fourth week.

Barn Sivallows.-Arrive from South third week.

Tree Sicallowis.-Arrive from South first week.

Bank Sucallows.-Arrive from South second week.

Rough-ainged Swallows. - Arrive from South second week.

Northern Shrikes.-Depart North second week.

Red-eyed I ireos.-Arrive from South fourth rieek.

Yellow-throatid Vires. - Arrive first week.

Blue-headed Vireos. - Pass North fourth week.

IV hite-eyed V'ireos.-Arrive fourth week.

Black-and-White Warblers.-Arrive from South fourth week.

Black-throated Blue and Yellow-rumped, or IIyrtle Warblirs. - Pass North fourth week.

Masnolin, Blackburnian, and Black-thronted Green WVarblers. - Pass North second and third weeks.

Yellow Realpoll, or Palm Warblers. - Pass North fourth week. 
Oven-birls. - Arrive from south third week.

Maryland Yellow-throats. - Arrive from South third week.

Yellow-breasted Chats. - Arrive fourth week. Cat-birds.-Arrive from South third week. Browon Thrashers. - Arrive second week.

House Wrens. - Arrive from South first week.

Wintir Wrens.-Depart North third week.

Chickadee.-Nests third week; tree holes.

Wood Thrushes. - Arrive from South fourth week.

Veerr, or WVilson's Thrushes. - Arrive from South fourth week.

Hermit Thrushes.-Pass northward all the month.

Robin. - Nests third week; orchard trees.

Blucbirl.-Nests second week; tree holes, bird boxes, and carities about buildings.

\section{FISHES}

Sea Lamprey's. - Ascending rivers to spawn.

Catfish.-Caught plentifully.

Mud Minnow. - Spawns in brooks.

Ilerring:-Approaching the coast.

Alewife.-Arrives early in the month.

Shad. - Arrives and fishing begins first week.

Silmon.-Enter the Hudson and northern rivers on their way to spawning-beds.

Tautog.-Coming inshore.

Trout.-Fishing begins.

Striped Bass. - Taken with the shad.

Lobsters.-Begin spawning.

Mussels and various other mollusks and annelids spawning. 
BATRACHIANS AND REPTILES

Spotted Salamander.-Laying eggs in still water in masses.

Marbled Silumander.-Eggs laid first week.

Toads. - Pairing and moving towards ponds.

Frogs.-Noisy ; tadpoles hatching.

Piepers (Hyla pickeringii). - Laying eggs first week.

IVood-frog. - Common about sphagnum swamps.

Snakes. - Become active towards end of month.

Turtles.-Become active and seek mates.

Box 7 ortoise._Latest to appear, fourth week.

\section{INSEC'TS}

Hornets and Yellow-Jackets.-Queens start. ing new nests in trees or under rafters and stones.

Brozen Wasps.-Queens flying about; start. ing new nests uncler shelter of various sorts.

Bumblebees.-Queens visiting willows and other early blossoms to get nectar and pollen ; flying close to ground looking for nesting sites ; starting nests in old mouse-nests or under shelter on ground.

Mud-ivasps and Digrer W Wasps. - I arvæ changing to pupæe and latter to adult in their mud-cells or earthen burrows.

Ants.-Workers repairing colonies and resuming activity for the season.

Ichneumon-flies and other Parasites. - Come from shelter or change to perfect state and visit early flowers for food; also search for caterpillars and other insects in which to deposit eggs.

Currant Wurms.-Adilts mature and lay 
eggs in rows on the principal veins of under surface of leaves of currant and gooseberry.

Ground Beetles. - Adults become active, though still found much of the time under stones, logs, boards, or similar shelter.

Leaf Beetles. - Many species come from hibernation and begin to feed on leaves of various plants.

Buprestid Beelles. - L arvæ resume activity in boring in trees and logs.

Ladybird Beetles. - Adults come from places of hibernation and wander about in searcls of food.

May" Beetles or "June Bugs,"-Larvæ (white grubs) begin feeding again on roots; beetles still in pupal cavities; to be found in ploughed ground.

Click Beetles. - Larvæ (wire-worms) in soil, feeding on plant roots; adults in pupal cavities in the soil or emerging therefrom.

Longicom Beetles. - The cylindrical larvæ re. sume burrowing operations in trees and logs.

Bee Flies. - I ppear on wing, visiting blossoms of willow, arbutus, and other early flowers.

Honse Flies. - Adults come from winter shelter and begin egg-laying in refuse-heaps and manure-piles.

Crane Flies.-Larvæ (leather-jackets) still in soil of grass-lands or changing to pupæ.

Gall Flies. - The larvx of many species of gall-makers in galls on willow and other plants change to pupre.

Mourning Cloak Butterfly and other relation species. -Adults come forth from wood-piles. brush-piles, hollow trees, or other shelter, and fiy about, visiting willow and other blossoms, and perhaps laying eggs. 
Asterias Butterfy.-Develops from chrysa. lis and appears on the wing.

Cabbage Butterfies. - Emerge from chrysalids and fly over meadows and gardens.

Viceroy, or Disippus Butterfly. - Iarva emerge from winter cases and feed on leaves of poplar and willow.

Splinx Moths. - A few early moths may appear, but most remain in soil as pupæ.

Cecropia and Promethea Moths. - Still in cocoons.

Polyphemus and Luna Moths.-Remain in cocoons.

Tiger Moths. - Larvæ of some species spin cocoons and change to pupæ. The commonest caterpillar that does this is that of the Isabella tiger moth.

White-marked Tussock Moth.-Still in eggmasses on elm and other trees.

Cutworm Moths. - Larvæ (cutworms) begin feeding on grasses and vegetal)les at night; seek shelter of soil or boards during day.

Noctuid Moths. - Many species flying at night, visiting willows and attracted to lights.

Fall Canker-worm.-Eggs hatch into larvæ that feed on opening leaves of apple and elm.

Budworms. - Larvæ begin feeding on opening buds of apple.

Leaf-miners. - Larvæ of many species change to pupæ.

Caddis-fies.-Larvæ in cases become active, feeding in the water of ponds and streams.

Squash-bugs and similar species.-Adults come from shelter and begin seeking food.

Water-huss. - Resume activity in ponds and. streams.

Cicadas.-Larvæ still in the ground. 
Tree-hoppers._Eggs still on twigs of trees and shrubs.

Leaf-hoppers. - Adults resume activity, sucking sap of leaves and grasses

Scale Insects. - Eggs beneath scales yet unhatched.

Plant-lice, or Aphiides.-Eggs hatch into tiny aphides that suck sap from the unfolding leaves. Those hatching in ants' nests are carried to food.

Red-lesged Locust, or Grasshopper, and its allies. - Eggs still in ground.

Coral-ainged Locust. - Well-grown nymphs active.

Grouse-locusts. - Adults become active, perhaps lay eggs.

- Tree Crickets._Eggs still in canes and twigs.

Black Crickets.-Mostly still in eggs in the soil.

Wulking-sticks. - Still in eggs on ground scattered beneath trees.

White Ants.-The colonies in the ground or in stumps and logs become active again.

Stone-flies. - Larva still under stones in water.

Dragon-fies.-Immature forms in ponds and streams become active again.

May-fies.-Nymphs resume activity; a few may change to adults.

Sprinstails and Bristletails-Nany on rub. bish and under boards, logs, and stones, as well as over the surface of the ground and on bark 


\section{A Y}

"Morn wakes in mist, and the twilight gray Weeps its bright dew, and smiling May Melts into blooming June." 



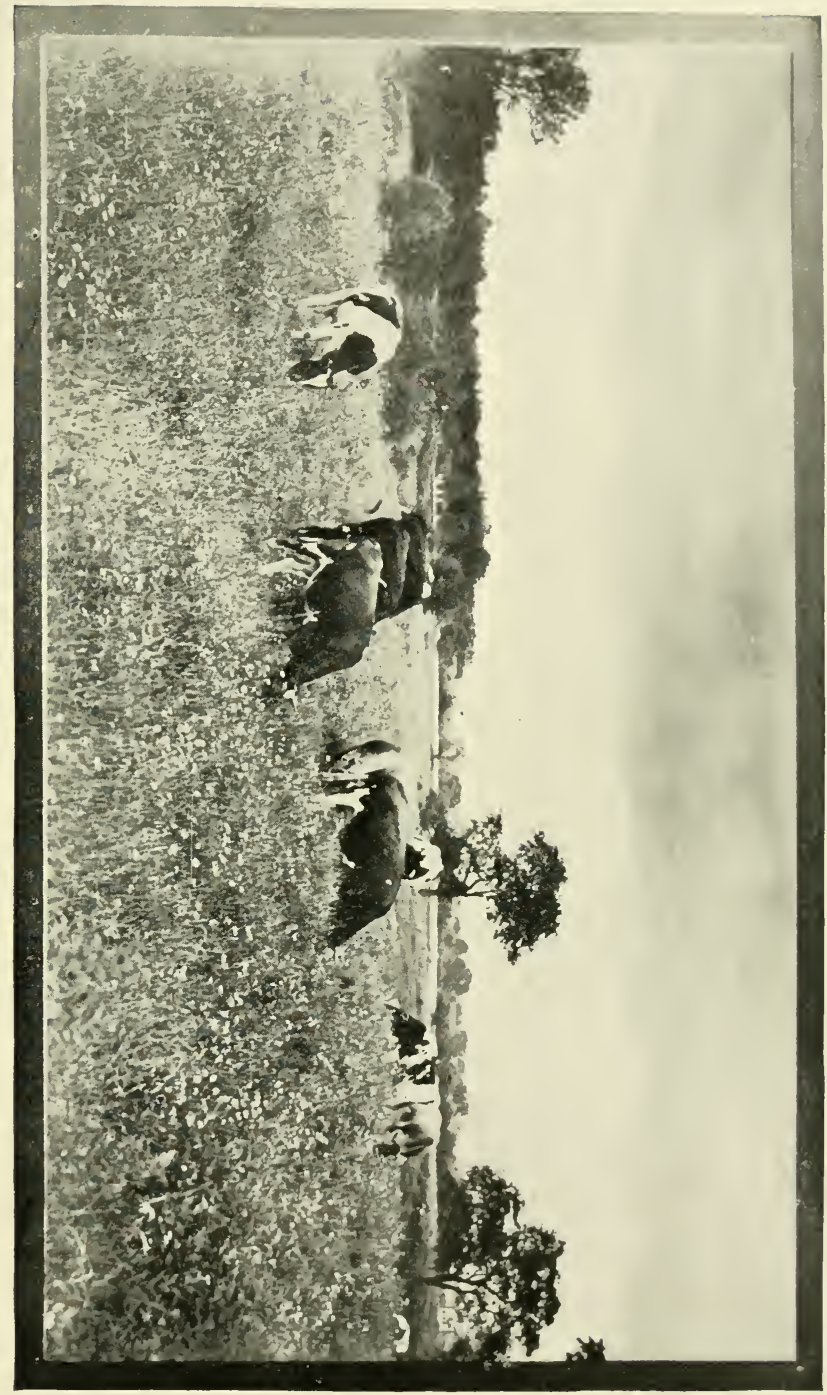





\section{MAY}

As April was the month of migrating fishes, so May is to be regarded as the month of migrating birds throughout the middle parts of the United States. In the case of the fishes the coming seemed regulated chiefly by the matter of temperature-none arrived anywhere until the water had reached the right degree of warmth. The coning of the birds, however, seems to depend mainly upon the matter of food. The great body of bird migrants from the South must not reach the northern districts until nourishment has been prepared for them. As, however, the insect food, upon which most land birds depend, at this season in particular, cannot itself develop plentifully until vegetation has advanced to a certain stage, and as this is dependent largely upon warmth, we may say that temperature finally rules here also.

May is a month of uncertainties in the Northern States-the English April; but under its warmer suns the buds and leaves struggle steadily against adversities and crowd forward. The grasses and weeds have already made good headway; and the fruit-trees, most shrubs, the ma- 
ples, and the majority of forest trees have come into full leaf by the end of the month, even as far north as the Great Lakes, while the roadsides, gardens, orchards, and meadow lands seem finished for the sunmer. To the Delaware Indians it was the "moon of the beginning of summer."

No season is more enticing to the rambler and the rural fisherman. The air is soft and dry, the whole earth is freshly green and full of pleasant odors. Life is stirring and multiplying on every side. and all nature speaks of the promise of summer and fruition, and invites us with such urgency to come and witness her joy, that confinement in the house is never more irksome than now, and attention to work and duty is an effort of will.

"Then weary is the street parade,

And weary books, and weary trade;

I'm only wishing to go a-fishing-

For that the month of May was made."

First of the season's interests to the rambling naturalist is the northward migration of the birds, now at its height. This movement began, as we have seen, even in March, and has grown slowly until now. During April the last of the winter visitors departed for their northern homes, leaving the all-the-year-round residents to begin theirsummer work and joys; they are quickly followed by the 
advance guard of those who, in the autumn, had retreated only a little way

south, and now take the earliest opportunity to edge back.

Thus April brings, north of Maryland in the East and the Ohio River in the West, a good many of the hardier and more familiar of our summer birds, some of which may get well settled, and even at treeding, before May-day. In the neighborhood of Cincinnati, then, or about Philadelphia, one may see by the middle of April the commoner thrusies and wrens, the bluebird, the yellow warbler, and oven bird; all the swallows and swifts ; the savanna, field, chipping, song, swanı, and some more obscure sparrows and finches; half a dozen kinds of blackbirds, crows, and jays; the phobe-bird and perhaps a kingbird or two; two or three woodpeckers, most of the hawks and owls, and the wild pigeon, among land-birds; while of the water-birds the commoner snipes and plovers and the various marsh hens are early comers; and already many ducks have passed on to their far northern breeding-grounds.

But when April's chills have gone woods, roadsides, and gardens suddenly fill with songsters, and May becomes a "merry month" indeed. The bobolink rollicks in every meadow, chaffing the crazy-headed chat above the thickets along its margin; swallows gleam and curvet in the air, the vireo exhorts us 
from every grove; the thrush, oriole, finch, and cuckoo mingle their strains in the richest chorus of the year, and the tree-tops sparkle with the flitting forms and tinkle with the bright singing of countless gayly dressed warblers. IVe may see anywhere more birds in May than at any other time of the year, because now we make a passing acquaintance with many that do not remain with us, but only flit through on their way from tropical winter-quarters to summer residences far to the north.

The migration of birds has been noticed ever since men began to make note of anything in the world about them, yet many mysterious questions in regard to the influences that produce it remain unanswered. But, though we cannot explain the why, we have learned much as to the how of this movement, which is so peculiar to and characteristic of birds as a class. We know that as winter approaches from the poles it drives southward before it-or northward, in the southern hemisphere-the birds which inhabit the polar regions in summer. Some who are hardy and able to pick up a living in a cold and snowy region from seeds and dormant insects go only a little way southward, and become the winter visitors to the temperate zones, where others reside comfortably the whole year round. Many birds, however, are not content even with the open fields and 
comparatively mild weather of our Southern States, but press on, picking up more and more recruits, until they find themselves well within the tropics. Of the peculiarities of this southward movement in autumn I shall have more to say when I reach that part of the calendar; let us now consider what happens in spring.

As the end of the dry season approaches in the tropics, the birds that have been wintering there grow restless and gather into companies, some to go to New Zealand or South Africa or the Argentine Republic, but far more (and, of course, different ones) to Northern America, Europe, and Asia, because there is more land in that direction. Just then the tropical residents are preparing to nestle (migrants never breed there, with a very few exceptions), the rainy season is bringing out flowers, fruit, and insects, so that bird food is growing abundant, yet away go these restless wanderers on their long journey poleward, moved by reasons we cannot yet perceive.

Some always start much earlier than others-perhaps a month--each species or group keeping to its habit in this respect. They form little companies, usually from two or three similar species, and these grow and gather others as they proceed. They follow particular routes. Our own birds, for example, enter the United States by three main roads. One set follows the Pacific coast; another, 
and the greatest, comes up the Caribbean and Gulf coast, avoiding the Mexican interior; and a third follows the line of the Antilles and Bahamas to Florida and the Carolinas. They travel slowly at first, and straggle into our southern border by twos and threes; but soon the foremost are overtaken by others, anxiety to get on urges their wings, and they hasten more and more, taking longer flights and less rest, ever gathering numbers. They infect the more northerly sojourners with their unrest, and start them, also, northward, until at last, in May, a great throng of hurrying little travellers races through our northern woods. Many stop here while others push on into Canada, or even to Alaska and the Arctic plains and coasts.

More and more as they proceed they fall into certain established routes. Thus the States of the eastern coast and New England get all their birds by way of the sea-coast, for these divide from the great body at the southern end of the Alleghanies. The interior of the country is supplied by the valley of the Mississippi, and by following up its several tributaries. Southern Ohio, for an instance, is almost wholly supplied by way of the Ohio River, not across the mountains. The reasons for this are mainly two: First, the rivers form an excellent guide; second, these water-ways abound in food to a much greater extent than do the 
mountains, cold and forest-clothed. Whatever that vague thing "instinct" may have to do with starting birds upon their migration, it has no part in leading them. They guide themselves, as we would do, by landmarks and memory; and by fcllowing the older ones. This leads me to note that in all cases the older male birds go ahead, and the females and young follow, sometimes a week later, towards the end of the journey.

They travel -mainly by night, summoning one another to assemble as clusk approaches, then rising together high in the air-sometimes, it is believed, a mile high in clear nights - then heading away on their course like a ship leaving port; and with the earliest dawn, sinking down to the earth to rest. All day long they flit about through the trees and bushes in leisurely content, progressing gradually on their way if the weather be good, singing, taking naps, and feeding, until the evening bids them renew their journey.

If the weather were always favorable the birds would thus come to us, or march past us, in regular platoons like soldiers, and we might know the precise day (as even now we may nearly) upon which they would return; but "cold snaps" and rain and head winds check and confuse them. Then they seek such shelter as they can find, and wait until warmth and sunshine come again upon 
the wings of the south wind. Hence, after a period of bad weather (and the second week of May is almost always stormy), observers note that the trees, almost silent for days before, are filled with birds, many not previously seen, and they say that a "migration wave" is at hand. Thus in wave after wave, hastening forward through the moonlight or the starlight nights, struggling along in the warm, rainy dark, loitering by day and pausing whenever storms block the way, they press forward-each to its wellremembered home. Few are mated when they arrive, but this is speedily attended to when the place of their choice is reached and the slower hen birds have overtaken them; so that by the end of May the majority of our resident birds of the United States have built their homes and are laying their eggs, and morning and evening the air is filled with their songs.

To the long list of small white April flowers are now to be added larger, gaudier blossoms with more coloring, while the chestnuts stand boldly out from their background of hill-side woods in a garb of yellow blossoms. Yellow, indeed, is a color highly characteristic of the blossoms of May. Dandelions still bejewel the lawns; out of the lush meadows rise great globular tufts of golden mustard, and lower down creeps the modest five-finger and the yellow 
violet, bastening to complete the duty of blossoming before the weeds shall smother them. Wild indigo, the polished buttercups, the marsh marigold, beloved of the gold flies, and many another, reward the seeker after this rich hue, yet by no means exhaust the catalogue that rewards him who goes a-Maying with a "botany-box" slung over his shoulder and a trowel in his belt.

In May the bluefish first appear and ascend salt-water bays, young ones sometımes going up the Hudson as far as IVest Point - but this is later in the season. Spring mackerel and sea-bass begin to be sold in the New York markets also by the middle of the month. The kingfish arrives, and sheepshead and mackerel become abundant off New York with great suddenness, seeming to have come in droves from the South, and to be feeding principally on small marine crustaceans. In a similar way scup, or porgies, are seen in large schools, which increase towards the end of the month, and resort to the eel-grass to spawn. Menhaden arrive, the shad-fishing continues through the month, and ale-wives become abundant.

Young perch are already abroad in the South, but in the Delaware River and northward they are just spawning, as also are the white perch, and in the West the pike-perch. This is the month, too, when the great, ferocious mascalonge 
voids its eggs. Says Henshall: "The mascalonge, like others of the pike family, breeds in the spring, later, however, than the pike or pickerel. All of the pike species resort to overflowed marshes and shallow, grassy streams-the pickerel during March and the mascalonge in May. The pickerel thus has a start of about two months, and no doubt the young pickerel devour most of the mascalonge that hatch, for the spawn in May, in such shallow water, is exposed to the ravages of turtles, frogs, ducks, and coots, and most of it is doubtless destroyed. This seems to be a wise provision of nature, for, as the mascalonge spawns from 100,000 to 300,000 eggs, according to size, the result can be imagined. It is, indeed, fortunate for the rest of the finny tribe that the mascalonge is comparatively a rare fish."

Black bass build their nests now preparatory to spawning. These are saucerlike spaces of gravel, in shallow water, constantly swept by their fins, in order that their eggs, which are heavy and sink to the bottom, may rest upon a clean surface. "It is interesting," writes Charles Hallock, "to note the pertinacity with which they guard their precious charges, and the vigor with which they drive away depredators and intruders of all kinds. They will frequently allow a boat to pass over them, scarcely six inches above their backs, and obstinately 
keep their ground. Sunfish and such are compelled to keep their distance.

There are hundreds of these bowl-shaped excavations, eighteen inches or so in diameter, all along the sandy shallows of the lake."

The striped bass are already spawning.

As to batrachians and reptiles, larvæ may be obtained of the spotted and of the marbled species of Amblystoma, and the adults of several others, most of the year terrestrial, are now inhabiting still waters, though the gray salamander must be looked for under stones in the woods, where it will be found in mated pairs. In warm waters the eggs of the green newt are hatching some thirty days after being laid, or longer in cool weather.

Toads go into the water in pairs by the first of this month, or a little earlier, and deposit their spawn. "To find the eggs," says Gage, "one should visit the natural or artificial ponds so commom along streams. . . The time for finding the eggs [in New York State] depends on the season. The toad observes the season, not the almanac. In ordinary years the best time is from the middle of April to the ist of May. One is often guided to the right place by noticing the direction from which the song or call of the toad comes. It may be said in passing that toad choirs are composed wholly of male voices. The call is more or less like that of tree-toads. In general it 
sounds like whistling, and at the same time pronouncing deep in the throat bu-rr-r-r-r-... The eggs are laid in long strings, or ropes, which are nearly always tangled and wound round the waterplants, or sticks on the bottom of the pond near the shore. If the eggs have been freshly laid, or if the water is clear, the egg-ropes will look like glass tubes containing a string of jet-black beads. . . . It takes only a short time for the eggs to hatch. In warm weather two or three days are usually sufficient."

Much the same remarks apply to the time and place of the breeding of the tree-frog (Hyla versicolor), which occurs in similar circumstances. Its eggs, however, are laid singly or in small clusters, attached to blades of grass or other supports in shallow water near shore. They hatch in about forty-eight hours, but their subsequent development is slow, it being some three weeks before the hind legs are well developed, and another three weeks before the fore-legs are free and completely formed.

The rare and curious spade-foot toad may also sometimes be found this month. It is a species well distributed, but local and rarely seen, as it burrows deeply, and sometimes intervals of several years elapse when it will not appear nor be heard in a locality. "The eggs are laid at any time from April to June in bunches from one to three inches in diameter, 
and are placed around a spike of grass.

They hatch in about a week, the metamorphosis being complete in about two or three weeks. The young immediately assume the terrestrial habits of the adults." The fullest account of this strange and vociferous little batrachian will be found in the writings of Dr. C. C. Abbott.

These are the latest of the batrachians to breed, and May sees much further advanced the tadpoles and young of the other species. The wood-frog, in particular, has now become silent and returned to his habitual home, and Pickering's treefrog ceases peeping long before the "treetoad" slackens its clucking.

The snakes are now wide awake and racing about in search of food, which leads them to frequent hay-fields, the abode of mice, and the vicinity of water, where frogs are congregated. Young frogs and toads offer an increasing and easily caught prey. This consequently is a month when it is well to be on the lookout for the copperhead, which is now passing to such feeding-grounds from his winter-quarters in some rocky hillside, and hence is likely to be met with in roads, paths, and door-yards, wherever this baneful creature is at all prevalent, as unfortunately he is along the Hudson Valley. The same warning may be given as to the rattlesnake in Connecticut and in the Alleghany Mountains. 
Few snakes are born so early in the season, but one of these exceptions is the common hognose, or spreadhead, which lays about twenty-five eggs in the sandy soil. According to Dr. C. C. Abbott, these may sometimes be found (in central New Jersey) in May. This month seems to be the regular breeding-season in southern New Jersey of the pine, or bull snake, a circumstantial account of which appeared in the American Naturalist for 1893, p. 878 . In this case the snake wormed its way head-first into the dry soil of a cultivated field, until it had concealed its whole body in a sort of tunnel some six inches beneath the surface. Early in August these eggs were exhumed, and found to be a cluster of ten, well glued together, sonie elongated and some nearly globular, averaging about two inches and a quarter long, and having a parchment-like skin thinly encrusted with lime. The embryos then seemed nearly ready to hatch. Dr. Samuel Lockwood (.4m. Nat., ix., 3) had an adult captive which laid its eggs (in northern New Jersey) on July 18 , so that, like others, this species is probably variable in its breeding-time.

A turtle whose eggs are laid at this season is the soft-shelled one, whose females now come out of the water in search of sandy places, where they bury their egss, generally about sixty in number, after which she goes back to the 
stream, leaving them to be hatched by the warmth of the sun. These eggs are round, and have a shell more calcareous and brittle than is the case with most turtles.

This is the month when the out-door study of birds really begins, and some hints as to method may be helpful. If you are to succeed in really knowing much about them, you must establish personal relations with them in their own haunts, and this requires that you introduce yourself courteously.

You would resent the rudeness of a person so eager to know you that he burst your door and came into your parlor with a leap and a shout. So do the birds. You should go very quietly to their place of residence, and respect their desire for privacy and their timidity. Remember, that every bird looks upon you as a source of danger-an enemyuntil you have won its confidence; and you can never gain this unless you keep very quiet, avoiaing noise and hasty movements.

Do this, and you will soon find that the birds' little flutter of alarm has passed, and that they are almost as curious about you as you are in regard to thens; a little later they will forget your presence and go on in their affairs, which is what you most of all desire.

Having some book describing the birds, you will find that you also need a good 
telescope or opera-glass to aid you in seeing the birds well. It is undoubtedly true, though regrettable, that if you go deeply into ornithology, and try to make yourself thoroughly acquainted with every species in your neighborhood, you must use a gun, unless you have access to some collection of bird-skins by which you can study the small points of difference which distinguish species that at a distance look confusedly alike. But a beginner has no need to shoot, and I shall assume that your study is not of dead but of living birds.

The early morning is the best time of the day. Birds are early risers. The air is cool, the light is good. The birds are hungry and so busy in feeding that you not only have the best opportunity to learn what they eat, and how they find or capture it, but they are less timid than later in the day. Their songs, too, are never so joyous and frequently repeated as in the early morning hours, and consequently so easily to be learned and memorized.

It is not necessary to go a long way from home to find your material, unless you live in the heart of a great city, and even there the parks abound in feathered visitors. Early morning in Central Park. New York, or along the Wissahickon, in Philadelphia, or in Lincoln Park, Chicago, is as good a place for the young student as the heart of the Blue Ridge-bet- 
ter, in fact, for most birds forsake the woods and prefer village gardens and rural orchards, fields, and roadsides. No place is better than along some brook that flows through an old farm and has arching trees, thickets, and an occasional weed-patch along its course. In such circumstances birds find refuges and hiding-places in case of alarm from a hawk or weasel, and plenty of food, sunshine, and water.

Don't try to do too much at once. Be content to keep one bird under observation until you get well acquainted with him. Find a comfortable seat in some retired garden, or beneath an orchard tree, or beside a thicket, open your book and opera-glass, and then keep quiet and wait for whatever comes. You will not have long to wait, and you will get a nearer view and see more of the bird and its behavior than if you tried to follow it: if it goes away, never mind; it is likely to come back again, and the less you attract its attention the more it will exhibit its natural manners to your eager eyes.

Always have a note-book with you, and make use of it. It need not be an elaborate affair; a few loose sheets between the leaves of your hand-book wi'l answer all purposes; then when you go home write out in this volume, under the appropriate date, an orderly résumé of the day's results. Even a mere list of the birds noticed that day is better than noth- 


\section{May 18}

ing, but you will find much else to say, and the more you add as to the attending circumstances of weather, vegetation, insect life, and other accompaniments of bird life, the more light will you throw upon the reasons for the ornithological facts you have learned.

Few windows open so pleasantly into the temple of nature as that through which we look when we study the grace and beauty of birds. We should fall short of the highest advantage, however, if we learned merely to recognize the birds apart, and failed to get some idea of the larger world of which they are but one delightful feature.

Along the sea-shore crabs and shrimps of all sorts now begin to come inshore and spread over the tide-flats, to feed upon fish-spawn, bitś of carrion, etc., and towards the end of the munth they begin to shed their shells. Among these the most striking sight is the arrival of the king crabs, or horsefoots, at the time of the extra high tides accompanying the filling of the moon, intent upon roiding their spawn at the limit of high water.

A pair comes together, the male riding upon the shield of the female, to which he clings. "The female excavates a depression in the sand, drops her spawn into it, upon which the male emits the fecundating fluid, and the nest is at once deserted, the parents returning seaward with the retreating tide." Spawning 
may go on through June and July, and the eggs hatch in about two and a half months.

The lobsters, too, are spawning in Long Island Sound and neighboring waters near shore. "There is a great difference," we are told, " in the breeding-season on different parts of the coast. The lobsters from New London and Stonington often lay their eggs as early as the last of April or first of May, while at Halifax Mr. Smith found females with recently laid eggs in September. At Eastport, Maine, the females carry their eggs in midsummer." All the edible crabs now become common in market.

Meanwhile, in mountain woods far from the tide-flats, the winter bands of deer have broken up. The does, in some secure thicket, are beginning to nurse their spotted fawns, while their lords, with aching brows, are hiding in quiet dells, feeling the first throbbing growth of the new antlers, to the completion of which the summer will be devoted, and fighting the forest flies.

Early in this month, in the Alleghanies, and towards the end of it, in Maine and Canada, the guats that have survived the winter lay their eggs upon rocks just above the water of swift streams. These hatch in a few hours, when the larva crawls down into the water and attaches itself to some submerged plant, like a cress, or to some sunken leaf, and feeds 
upon its juices. After a few days it sinks to the bottom and forms a cocoon, in which it changes to the pupa stage, the pupa's head, having a tuft of breathing filaments, protruding from the top of the case, the "tail" of which is attached to the rock. After four or five days the complete fly escapes, rises to the top, protected from drowning by a coating of hairs, and flies away.

Many mammals, besides the deer, are now confined by domestic duties. Our common bats are with young, and so is the familiar white-footed mouse, which so often converts an abandoned bird's nest to its own domestic uses. This first brood will be followed by one, or perhaps two or three, more broods before the summer is over. The short-tailed shrew, abundant everywhere, has the same cares, to be repeated in July; and the cotton-tail rabbit is already preparing for the advent of a second family, while the larger northern, or varying hare, is in possession of her first litter of leverets. These are four to six in number, and rest upon a nest of straw made soft with pluckings of the mother's fur. Such larger rodents as the muskrat, beaver, woodchuck, and porcupine also breed in May. The little ones of the first two are born in the burrows in the banks of streams, inhabited during the larger part of the year by these species. The young woodchucks also come to life underground, 
in some dry chamber in the hill-side, or, perhaps, in an old log or dead stump. The porcupine can hardly be said to have a home, the prickly mother seekjng temporary safety in a hollow treetrunk, or in a little cave among the rocks. "Its young, generally one or two in number, are born about the ist of May, and are monstrous for the size of the species. They are actually larger," according to Dr. Merriam, "and relatively more than thirty times larger than the young of the black bear at birth."

This is the month when weasels bear young. Merriam says that the nests of the larger species, the stoat or ermine, "are usually made in an old stump or log-heap, or under some out-building, and from four to six young are commonly brought forth early in May." The young, he adds, are likely to remain during the summer in the vicinity of the nest. Thomas Bell, the companion of Audubon, recorded of the least, or New York weasel, that "the female brings forth four, or more frequently five, young, and is said to have two or three litters a year. The nest is composed of dry leaves and herbage, and is warm and dry, being usually placed in a hole in a bank, in a dry ditch, or in a hollow tree."

Three other fur-bearing mustelids are also breeding now - the mink, the sable, and the fisher, or pekan.

The mink nests in burrows or hollow 
logs, where its lair is well lined with feathers, and sometimes, it is said, with the fur of the female; though it might be worth while to examine carefully whether this fur is not that from hares and other victims of its rapacity. From four to six young constitute an ordinary litter, and the young follow the mother until fall.

As for the fishers, now rare even in the Adirondacks, "their nest is made in the hollow of some standing tree, generally thirty or forty feet from the ground, and from two to four young are commonly brought forth about the ist of May."(llerriam.)

In the insect world May is a period of renewed activity. Many species that hibernate as adults seem not to get thoroughly awakened from their long winter sleep until the warm days which so often conie early in this delightful month. The hornets, wasps, and bumble-bees go ahunting for house-sites, and the queens, which alone have passed the winter courageously, begin to build, relying on themselves alone, and destined to have no assistance until they can rear workers from the exgs they themselves must lay and care for. The ants also resume the manifold activities of the formicary, while various ichneumon-flies are abroad looking for any early worms to serve as hosts for their unborn progeny. In the garden the currant worms have hatched, and the 
white butterflies are laying the eggs from which the cabbage worms are to come.

Along the highways and in open glades the winter butterflies are disporting themselves, enjoying the warm sunshine that rewards then for the long, cold waiting in crevices and cracks of rocks and logs: Late in the month some butterflies that have wintered over as chrysalids make their appearance, fresh from their mummy-cases. In the orchard the canker-worms and the bud-worms feed freely on the young and unfolding leaves, while in the meadows a host of insects are at work among the grasses. The water insects, too, are again active, wandering about among the shadows on the rocky bottom, swimming freely through the water, or playing blithely on its surface. 


\section{May 24}

\section{CALENDAR FOR MAY}

\section{MAMMALS}

Nearly ail mammals complete the spring molt.

Moles.-Produce young underground.

Varying Hare.-Summer coat renewed; young born.

Woodchucks. - Produce young in burrows.

Beavers. - Produce young in bank burrows.

Porcupines.-Produce young in dens.

Wolves.-Produce six to ten puppies.

Fishers.-Breed in their forest dens.

\section{BIRDS}

Terns and Petrels. - Arrive.

Sheldrakes, Mersansers.-Pass northward.

Brants. - Depart northward first fortnight.

Sora, or Carolina Rails. - Pass northward.

Phaluropes. - Pass northward.

Dowitihers.-Pass northward.

Some bay-birds linger on their way North.

Bob White.-Nesting fourth week, on the ground in stubble-fields.

Ruffed Grouse. - Nesting second week, beside some fallen $\log$ in the woods.

Sharp-shin.-Nests fourth week, on trees and cliff;

Cooper's Hawuk.-Nests first week; tall trees.

Pigeon Hawoks. - l'ass North first fortnight.

Sparrow Hawk.-Nests first fortnight; old woodpecker holes and other tree-hollows.

Fish Hawk.-Nests first week; big trees.

(uckoos. - Arrive from south second week. 
Black-billed Cuckoo.-Nests fourth week; a rude nest in low trees.

Kingfisher.-Nests fourth week, boring a deep hole in a stream bank.

Flicker.-Nests second week; hole cut by itself in a tree.

Downy Woodpecker - Nests second week; hole cut by itself in an orchard tree.

Hairy Woodpecker. - Nests third week; hole.

Nighthawks.-Arrive from South first week. Sivift.-Nests fourth week: dead chimneys. Humming-bird. - Nests fourth week; orchard or forest tree.

Great Crested Kinghirds.-Arrive first week. Phabe-Nests first week, often beneath a bridge or porch; also on ledges of rocks.

Olive-sided Fly'catchers. - Pass North third week.

Wood Peivees.-Arrive from South second week.

Yellow-bellied Flycatchers. - Pass North last fortnight.

Acadian Flycatchers. - Arrive from South first. week

Fish Crowo.-Nests third week; tall tree. Blue Jay.-Nests fourth week; cedar-tree. Bobolinks. - Arrive from South first week. Red-rvinged Blackbird.-Nests third week; alders and bushes in swamps.

Orchard Orioles. - Arrive from South first week.

Baltimore Orioles.-Arrive first week; nest fourth week.

Rusty Blackbird.-Departs North first week. Purple Finch.-Nests third week; orchard tree. 
Vesper Sparrow. - Nests second week, on the ground in grassy fields.

Savanna Sparrozv. - Nests second week; dry fields, especially near the sea-coast.

Sea-side Sparrow's. -Nest last week; salt marshes.

White-croaned Sparrozos.-Pass North second and third weeks.

Chippins Sparrow.-Nests third week; bush.

Field Sparrow.-Nests third week; fields.

Soni Sparrozu.-Nests first week, under or in low brushes or on the ground.

Swamp Sparrow. - Nests third week, near the ground in wet places.

Chervink, or Towhee.-Nests on the ground in woods, usually on a hill-slope.

Rose-breasted Grosbeaks. - Arrive first week. Indigo-birds. - Arrive from South first week. Scarlet Tanagers. - Arrive first week.

Puple Martins. - Nests fourth week; bird boxes.

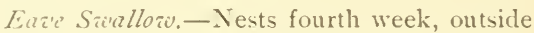
barns, making a row of "bottles" under the eaves.

Barn Swallow. - Nests first week, inside barns, making a nest of mud and feathers plastered against or laid upon beams.

Tree, or White-bellied Swallow.-Nests in birl boxes, or in holes in trees and posts.

Bank, or Sand Sïallow.-Nests; holes in earthen banks.

Roush-winged Swallow.-Rare. Arrives early; nests third week, in holes in stream banks.

Rid-eyed Vireo.-Nests fourth week; low trees, making a cup-like nest, hung by its rim in a forked branch. 
Warbling Vireos.-Arrive from South first

week.

Blue-headed Vireos. - Pass North first fortnight.

White-eyed Vireos. - Nests fourth week; low trees. All vireos' nests much alike.

Black-and.White, Blue-winged Yellow, and Worm-eatings Warblers.-Arrive from South first week.

Nashville and Parula Warblers.-Passing North first fortnight.

Summer Yellow-birds.-Arrive tirst week.

Black-throated Blue, Yellow-rumped, Chestnut-sided, Bay-breasted, and Black Poll Warblers. - Pass northward throughout the montl.

Prairie Warblers.-Arrive from South first week.

Oi'en-bird.-Nests late, on ground in woods.

Water Thrushes. - Pass North second and third weeks.

Maryland Yellow-throats. - Nests late, or the ground in swampy thickets.

Yellow-breasted Chat.-Nests fourth week; bushes.

Hooded Warblers. - Arrive from South first week.

Wilson's Black-caps.-Pass North second and third weeks.

Canadian Warblers. - Pass North second and third weeks.

Redstarts.-Arrive from South first week.

Cat-bird.-Nests third week; thickets.

Thrasher. - Nests third week; thickets, brush-lieaps, often on the ground.

House Wren.-Wests late, in holes and bird boxes. 
Marsh Wrens. - Arrive from South second week.

Browun Creeper.-Departs North first week. White-breasted Nuthatch. - Nests fourth week: old woodpecker holes and natural cavities.

Kinglets. - Depart North irregularly.

IVood Thrush. - Nests third week; low trees.

Gray-cheeked and Olive-backed Thrushes.Pass North last fortnight.

\section{FISHES}

Gar-pikes.-Spawning in the St. Lawrence.

Suckers. - Ascending small northern streams to spawn.

Mackerel. - Becoming abundant off the coast.

Shad-fishing.-Decreases and stops.

Menhaden. - Approach the coast.

Bluefish.-Arrive in New York Bay.

Porgies. Approach the coast.

Kingfish, Scup, and Sea-bass.-Arrive in New York Bay.

Rock Bass. - Are spawning.

Black Bass.-Preparing nesting-places.

White Perch.-Begin to spawn.

\section{BATRACHIANS AND REPTILES}

Harbled Salamander.-Young leaving the water.

Gray Salamander.-Found in pairs under stones.

Common and Spade-foot Toads. - Spawning and hatching.

Pickering's Tree-frog.-Ceases to peep.

Cricket Frog. - Lays eggs first week. 
Wood-frog. - Retiring silently into the woods, having completed its propagation.

Bull-frog.-Spawns last fortnight.

Copperheads. - Resorting to swamps and meadows in search of food and mates.

Hognose.-Laying eggs in southerly parts.

Mud-turtle.-Iays eggs first fortnight.

Soft-shelled Turtle. - Lays eggs middle of the month.

\section{INSECTS}

Hornets, Brown IVasps, and Yellow-Jackets. -Queens rearing young and enlarging nests.

Bumble-bees.-Queens visiting many sorts of flowers, getting nectar and pollen to teed the young developing in the small combs of the newly constructed nests.

Mud-rvasps and Digurer Wasps. - Some species on the wing.

Ants. - Workers busy in many ways, enlarging or thatching the nest ; feeding young ; foraging; attending aphides, etc.

Ichneumon-flies. - Some species searching for caterpillars and other victims to insert their eggs; also sipping nectar of various flowers.

Currant Worms. - Larvæ, hatched from eggs laid in April, are feeding on the leaves of currant and gooseberry bushes.

May Beetles, or "June Bugs." -Adults appear flying to lights at night, feeding on leaves of trees, and depositing eggs in grass-lands.

Click Beetles. - Adults appear, visiting various shallow blossoms to sip the nectar.

Long-homed Beetles. - Some of the larve change to pupæe within their burrows in trees and logs. 
Tiger Beetles.-Some species running about in sandy places.

Ground Beetles.-Abundant, wandering over ground in search of cutworms and other victims.

Leaf Beetles.-Many sorts lay eggs on leaves of various plants. Eggs hatch into young that feed upon the leaves.

Buprestid Beetles. - Some of the larvæ change to pupæ.

Ladybird Beetles. - Some species lay eggs on bark of trees and in other situations. Eggs hatch into the peculiar elongate larræ.

Bee Flies (Bombylidx). - Abundant, visiting many sorts of flowers.

House Flies. - Adults continue egg-laying; early stages grow rapidly.

Crane Flies. - Adults appear, flying slowly over grass-lands and in other places.

Gall Flies. -Adults of many species appear and lay eggs for young.

Baltimore, or Phaton Butterfy. - Caterpillars which have hibernated become nature and change to chrysalids; live in swampy places. where they feed on leaves of Chelone and other plants.

Violet-tip Butterfy. - Adults come from hibernating-quarters and fly over fields and along highways.

Hop. Merchant, or Comma Butterfly.-Adults flying about, secking elm and hop leaves, on which they deposit their eggs.

Gray Comma, or Progne Butterfy.-Adults still flying, laying eggs upon currant and wild gooseberry plants.

Mouming Cloak, or Antiopa Butterfy. Adults continue on wing; about the middle of 
the month they lay eggs in clusters on twigs of willow, elm, and poplar.

Red Admiral Butterfly. - Comes from winterquarters and appears on the wing in fields and along roadsides.

Painted-lady Butterfy. - Hibernating butterflies appear on the wing about the middle of the month, and continue to be seen for four or five weeks.

Spring Azure Butterfy.-More abundant than in April, three varieties of the species occurring in the latter part of the month.

Gray Hair-streak Butterfly.-Adults appear in fields, and continue to be found all summer.

Imported Cabbage Butierfy.-Adults common in fields and gardens, depositing eggs on cabbage and other cruciferous plants.

Clouded Sulphur Butterfy. - Burtterflies of first brood appear.

Green-clouded Swallowtail. - Adults come from chrysalids, the males appearing about a week before the females.

Black Swallowtail, or Asterias Butterfly.Adults emerge from the hibernating chrysalids during the latter part of the month.

Cutworm Moths.-Larva of some species pupate in the soil.

Canker-worms, - Larve feeding upon the leaves of apple and elm.

Leaf-miners. - Moths of many species come from pupæ and deposit eggs.

Caddis-fies. - Larvæ still to be found in abundance in ponds and streams.

Hellgrammites. - Larvæ leave water and seek shelter under logs to pupate.

Squash-bugs and similar species.-Continue 
active, feeding upon their food-plants, and laying eggs for new broods.

Tree-hoppers. - Late in the month eggs hatch into young hoppers.

Leaf-hoppers.-Young of new brood appear, being especially noticeable during the latter part of the month.

Scale Insects. - Towards the end of the month the eggs hatch.

Plant-lice, or Aphides.-Young from winter eggs mature and give birth to new broods.

Red-legged Locust and its allies.-Eggs hatch towards the end of the month if season is forward.

Coral-zinged Locust.-Adults appear.

Tree Crickets. - Eggs hateh near the end of the month.

Black Crickets.-Siome young hatch from eggs late in May.

Dragon-fies.-Adults of some species appear, and are chased by martins.

May-fies.-Adults appear, becoming more abundant towards the end of the month.

Springtails and Bristletails.-More common in rubbish and under stones, and continue abundant throughout the summer. 


\section{J U NE}

"There is a quiet spirit in these woods, That dwells where'er the south wind blows; Where underneath the whitethorn, in the glade The wild flowers bloom." 



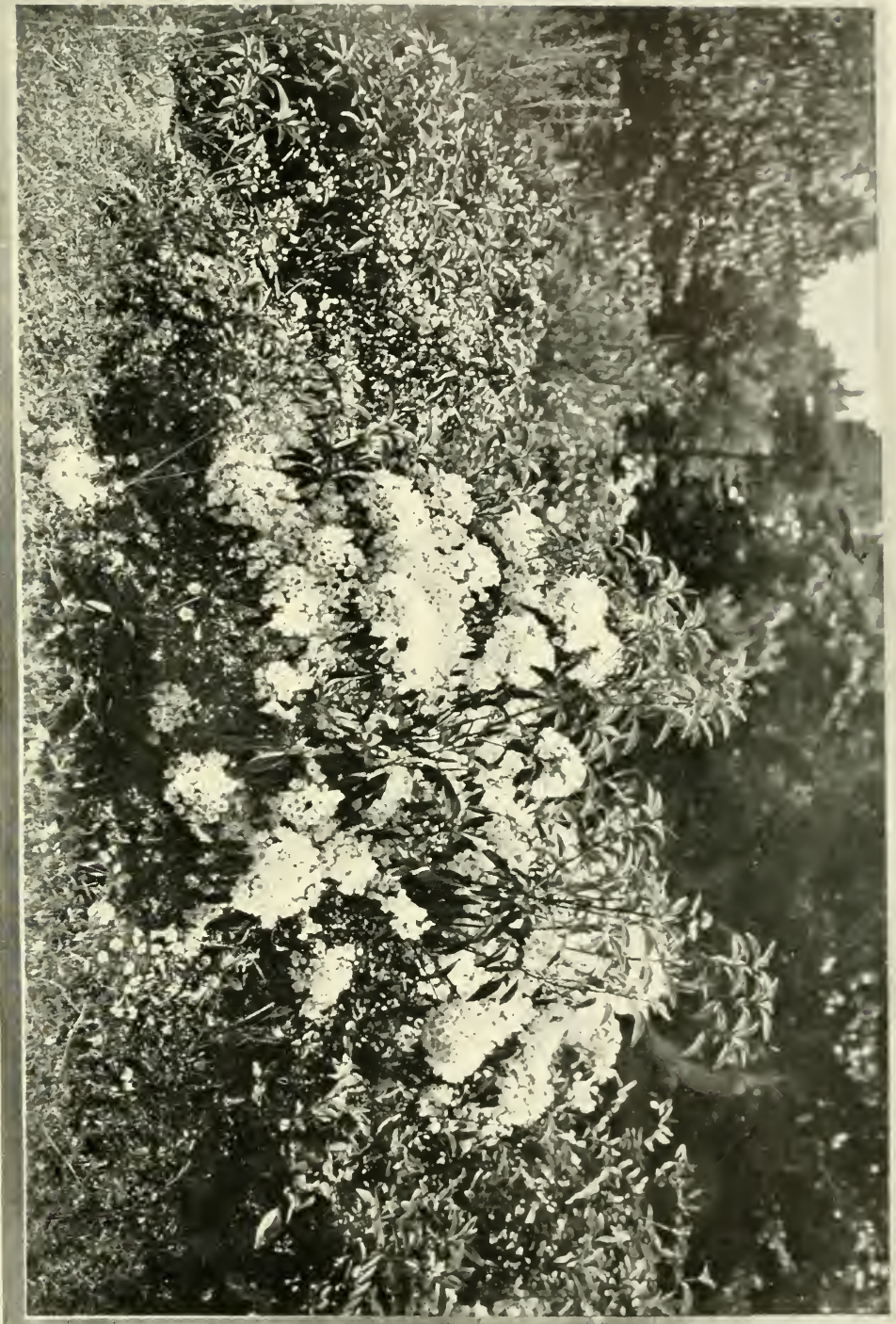




\section{JUNE}

As May was the month of the coming of the birds, with bursting forth of leafage and bloom, so June is distinctly the month of their home-life. Some-early beginners--have already a family to engross their attention; others are sitting on their eggs, while still others are just constructing their nests; but, in some degree, all birds are domestic in June.

This means that they are doing more than simply making nests or watching eggs or callow young. It means that they are wearing the brightest plumage and uttering the brightest songs of the year, for now is the culmination of the bird year, and all deck themselves for it - "a livelier iris comes upon the burnished dove." In some cases special ornaments are added to the plumage, to be shed at the next molt. Such is the aigrette of the white herons, now exterminated from Florida, and in danger of extinction elsewhere through the rapacity of gunners who kill them to get the lovely back tufts for the milliners' use. The most striking example of this special breeding costume in our eastern fields is that of the goldfinch, which, dull and in- 

year, is now brilliant and brave in a suit of sable and gold. The bobolink is another example.

The singing of the birds is now at its climax, too-the crowning grace of this sweetest month of the year. How much of the joyousness of June is due to their melody! How it welcomes the rising of the day upon a blooming and odorous world with glorious matins, and ushers in the evening with vesper hymns! But every hour of this happy season is ringing with bird music, as it is redolent of the perfume of flowers. One hears, first of all, at the earliest gray intimation of dawn, the cheerful summons of the robin. The phœbe is quickest to make response to this reveille, but it is hardly light before all the others are awake and in tune. From the borders of the distant wood come the rollicking whistle of the cardinal and the staccato notes of that other "redbird," the fiery, black-winged tanager, while shrill exclamations from flickers and oven-birds and redstarts strike through the softer, more continuous melody of the thrushes. In the deeper woods, at sunrise, the illumined arches of the trees are vivid with the gay coats and pleasant chatter of warblers, flycatchers, and titmice. The meadows and pasture-lands echo to the jolly roundelay of the song sparrow, the prattling of field sparrows and indigo-birds, while the 
crazy bobolinks, hovering over grass or

grain, are no wilder in their antics than are the yellow-breasted chats that turn somersaults above the roadside thickets. Here and in the orchard are heard, in the brisk morning air, the warbling of the vireos, the clear carols of the two orioles, the brilliant performance of the rosebreasted grosbeak; while close about the house, as we step from the door to take a look at the morning, our ears are pleased with the exquisite voices of wren and yellow-bird, vireo, chebec, blackbird, and half a dozen other intimate friends.

This singing of the birds in the spring -and at no other season do they truly sing, for the calling notes are differentis an expression of their joyous excite- . ment over this time of love-making and domestic happiness. It is directed mainly towards their mates, and is a part of the display by which they seek to win and keep them. Rivals sing against one another, and sometimes these contests are amusing to listen to, as, for example, when the whippoorwills try to race one another out of breath in their moonlight chorus. There is good reason to believe that this singing has been gradually enlarged and perfected during past ages by natural selection, just as the brilliant dresses worn by many male birds have been acquired in contrast to the plain suits of their brooding mates.

Why do birds choose this early part of 
the summer-as early as possible, in fact - for their home-making, instead of a later, warmer season? Plainly, in order to have time to rear their young into the strength enabling them to travel southward, if they be migratory in habit, or to endure the winter, if they remain with us the year round. Moreover, it is in May and June, more than later in the summer, that proper food for the young can be obtained. This consists almost wholly of worms, and the larvæ of insects, caterpillars, grubs, etc. Seed-eating birds, as well as the insect-killing ones, must have this sort of food for their fledgelings, and must obtain it in great quantities; hence they must hatch their eggs at the season when young insects most abound.

In view of this fact, it will be proper for us to describe briefly the situation of the nests of the birds more commonly to be found now in the eastern United States.

Both the cuckoos are nesting early in the month, though the black-billed is rather more hasty in beginning than the yellow-billed. They build rude nests of twigs, coarse weed-stems, pine-needles, etc., and place them in low, dense trees, like evergreens, usually close to the trunk.

All of the flycatchers, except the hardy and hasty phœbe-bird, postpone their nidification until June, and present, in the great variety of their nesting, an interesting exception to the rule that birds nearly related are similar in their architecture. 
This diversity is especially striking in the case of the small "tyrant" group. Thus the phobe-bird erects a home of mud and living moss, almost as big and heavy as a robin's nest, and glues it against a wall, or sets it on a rock-shelf, or on some stone or timber about a bridge or house. The chebec weaves a little cup of hempen shreds and other soft materials, hardly distinguishable from that of the summer yellow-bird, and, like that garden warbler, sets it snugly in the upright fork of some garden bush or shade-tree by the roadside. For the home of its cousin, the little green, or Acadian, flycatcher, however, you must go to the woods and search the ends of the boughs of low trees, where it will be found suspended, like a slightly woven hammock, across some horizontal fork. Wholly different from any of these methods is that of the wood pewee; its nest is an exquisitely soft cup set upon the top of some stout limb. Usually an old, half-dead branch is chosen, more or less overgrown with lichens, and these very lichens are plucked here and there by the careful bird and glued to its nest, so that the little cup is made to look like a natural excrescence.

Our two kingbirds, the common "beemartin " and the great-crested flycatcher, make bulky nests of coarse materials. The kingbird puts his usually in an orchard tree, but the great-crested flycatcher chooses some cavity in a tall 
stump or broken tree, and has the singularity of weaving into his structure the cast skin of a snake-usually that of the milk-snake.

The orioles are the latest of the starling tribe to begin housekeeping, and of these the orchard oriole is more tardy than the Baltimore. Its nest is not hung, like the safe pouch of the Baltimore, among the drooping, flexible ends of outer branches, but is composed of grasses woven into a thick, deep cup, half hung in the fork of some apple-tree.

Two other very late nesters in orchard and garden are the cedar-bird, or cherrybird (a waxwing), and the goldfinch. The former makes a compact nest placed in some orchard tree. The goldfinch is almost equally late in its nidification, choosing for the situation bushes and low trees in pastures, along country roads, and in our gardens.

The sparrows are mostly early breeders, but several prepare nests for second broods in June ; and some of the groundkeeping species, like the yellow - winged, may wait until the early part of the month to lay their first eggs. The indigobird, however, is late in its house-building, waiting usually until the roth before laying its eggs in the pretty cup that it fastens securely in some fork of a bush or sapling in the thickets at the edge of the woods or along field boundaries. No place is so beloved by small birds as the 
bushes and vines and seed-bearing weeds that hide neglected fences and stone walls; and here, in a somewhat larger tree, is placed the rough home of the rose-breasted grosbeak, and perhaps also that of the scarlet tanager, though that gay fellow likes better the seclusion of the woods, for his wife at any rate.

Another conspicuous June breeder, in localities where marshes favor their presence, are the marsh wrens. These construct hollow balls, as big as one's head, made of blades of the marsh-grass, and hung among the reeds to which it is firmly bound. The entrance is a hole in the side. Whether it is necessary to wait until the reeds have grown to a certain height and thickness, or whether some other reason prevails, at any rate these active and noisy little creatures, which arrive early in May, do not get at their egg-laying until the middle of June.

June is the breeding-month of such of the warblers as remain to nestle in our latitude, and the list includes some of the most interesting and beautiful of this fascinating race. Commonest and bestknown of all these is the summer yellowbird, or golden warbler, whose trilling voice comes to our ears from every garden shrub. In such places, and especially among the boughs of the maples that shade village streets, it weaves its neat, hempen, softly lined nest.

Other tree-builders among the warblers 

black-throated blue, the cærulean, the prairie warbler, and the redstart. One of the hardest warbler nests to find is that of the blue yellow-back (Parula), which fabricates a home within a mass of the gray moss (Tillandsia) hanging from dead trees in swampy forests. It is nowhere numerous, and its nest is one of the prizes of the collector's fascinating pursuit.

Strangely, when one considers the diminutive size and the delicacy of warblers, many of them make their nests upon or very near to the ground. Thus the Kentucky warbler, of southerly range, hides its grass-woven nest at the roots of some brier or other bush in a swampy thicket, just like its northern relative, the Maryland yellow-throat. Other warblers hiding their nests in little nooks among the dead leaves of the woods and hill-side thickets, sometimes in tiny caves, and sometimes a little elevated among the stems of a low bush, are the Nashville, the worm-eating, the golden-winged, the myrtle-bird, the oven-bird (whose nest is neatly covered with a hut of leaves, like a towhee's), and its cousin, the long-billed water thrush, which must be looked for along a wooded brook-side.

Insects, as has already been explained in these pages, usually have only one year of life. The old ones die off for the most part in the fall, leaving eggs, caterpillars, or chrysalids, that last through 
the winter to come to life when warmth and vegetation revive in the spring. The eggs are laid with marvellous instinct upon the plants that form the proper and perhaps the only possible food for the caterpillar to be hatched out of them. The grubs and caterpillars that have been lying dormant during the winter in the ground, or under bark, or inside some snug retreat, in rotten wood or the like, also find proper food at hand when they awake--often highly improper food from our point of view, for they attack the roots or leaves of the plants we have been carefully cultivating.

The warm, moist days of May and June bring these caterpillars to life in countless thousands, and in every sort of place, so that there is enough of them in amount and variety to satisfy all the birds-more than enough, for now and then they overflow into the devastating "armies of worms" that destroy our lawns, meadows, grain-fields and shadetrees. Let us look at this subject of caterpillars a little more closely.

Many insects in the second (larval) stage of growth may be called caterpillars, but those in which we are especially interested at this season are young butterflies. Most of these are worm-like, with a conspicuous horny head, having well-developed jaws, and often long, flexible horns, by which they investigate their food and feel their way about. The 
body is composed of rings; the first three, back of the head, correspond to the chest of the fully developed insect, and the remainder (nine) to the abdomen; the skin is thin and loose, and perforated in each ring by a breathing pore. The chest rings have three pairs of stubby "forelegs," which will become the true legs of the butterfly, while the hinder part is usually supported by five other pairs of temporary feet. In the "inch worms," however (the wire-like caterpillars of many familiar moths), the feet are placed only at the head and tail, and these larvæ hunch themselves along by arching their bodies and measuring their length with each step.

Caterpillars are soft and juicy, nearly all feeding wholly upon green plants, and therefore they form the most easily digested as well as nutritious food for the baby birds, which consume a surprising quantity of them. But nature here, as elsewhere, has so arranged matters that no living shall be had without work, and that no creature shall be left without a fair chance in the world.

Some caterpillars are aided in their fight for life by the ability io remain hidden, forcing their enemies to dig them out of their castles; others conceal themselves by constructing some sort of a shelter from the weather and from prying eyes; still others go abroad, but are protected against the birds and other ene- 
mies by spines, or hairs, or the ability to throw out some offensive liquid or odor, or they are of such a color as easily to be overlooked. Thus caterpillars that draw together the edges of a leaf, forming a little house in which to conceal themselves, or that burrow in old wood or the pith of living plants, are usually nearly white, but those that travel about in view are so colored as closely to resemble the objects upon which they are accustomed to stay and feed. Most of them, therefore, are of the precise green of the leaves whose juices they suck; others are gray or brown, mimicking the bark and twigs upon which they crawl. Many, it is true, are of bright hues-yellow, red, or redbrown, black and white, or striped, barred and spotted with strong colors, foretelling the brilliant ornamentation of the winged adults to follow. Such are almost always guarded by their ugly knobbed or horned appearance, or by an armature of barbed prickles, or a covering of stiff hairs, or by special organs of defence. The caterpillars of the swallowtailed butterflies, for instance, are provided with a sort of double-barrelled gun which may be pushed out from behind the head, and it w:1l discharge an odor disgusting to insect-eating creatures. MJst caterpillars "resist arrest" by hurling their heads from side to side, or by causing their barbed and acrid spines or hairs to prick and annoy their enemies; these are usu- 
ally distinctly colored, and may thus be easily recognized and avoided. Many birds will not touch such caterpillars, while some, like the cuckoos, will seize the most hairy ones as quickly as any other, but beat them into a pulp before swallowing them.

When one remembers that most of these caterpillars, grubs, and other insect larvæ are destructive to plants, and that those which attack cultivated plants and trees are given a chance to multiply just as fast as we cultivate their customary foods, one can see how important it is to protect and encourage the birds that are almost our only means of keeping the insect hosts within bounds. The plainest common-sense enjoins this, and it ought not to be necessary to teach it or argue about it at all.

Before the month is out, a wide variety, as well as countless numbers of larvæ, have changed by molting into the pupa or chrysalis stage of insect growth, and are quietly developing into butterflies, moths, etc. Most of the chrysalids to be found this month are not protected by thick, felted, or paper-like cases, such as those of the winter-sleeping sorts, but are naked and smooth, and many are suspended by a point glued to some object, or else are hung in a sling or girdle of threars. They are dull-colored, as a rule, and readily overlooked, but once seen are easily recognized, for they re- 
semble the body of an adult insect much more than did the caterpillars. By the end of June vast numbers have burst, and the "imago" formed within has spread its wings and is lending interest and beauty to the scene as it flits from flower to flower: but next month will see even more of these exquisite creatures.

"Whether we look, or whether we listen, We hear life murmur, or see it glisten;

Every clod feels a stir of might, An instinct within it that reaches and towers,

And, groping blindly within it for light, Climbs to a soul in grass and flowers;

The cowslip startles in meadows green, The buttercup catches the sun in its chalice, And there's never a leaf nor a blade too mean To be some happy creature's palace;

The little bird sits at his door in the sun. Atilt like a blossom among the leaves, And lets his illumined being o'errun

With the deluge of summer it receives;

His mate feels the eggs beneath her wings, And the heart in her dumb breast flutters and sings ;

He sings to the wide world and she to her nest-

In the nice ear of nature, which song is the best?"

Early summer is a quiet season among the "four-foots"-as Mrs. Wright prettily styles the quadrupeds--who are engaged with family cares like the birds. Young 'coons, foxes, skunks, and minks 
are fairly well-grown and learning the road to hen-coops and cornfields; the prickly children of Father Porcupine are six weeks old or so, but Madam Muskrat has hardly let her youngsters out of the house yet. The porcupines come down from the trees now, and wander about the meadows a good deal, browsing on new grass; and at night they seek the edges of ponds, and gorge themselves on the succulent young shoots of sagittaria, and later eat the lilies.

All the squirrels have well-grown families, though those of the warmth-loving flying squirrels may hardly be weaned in the more northerly regions. The gray, fox, and red squirrels are moving about in family parties, studying their ways of life, living largely on maple keys, and nibbling at a good many of the harder sorts of chrysalids and such beetles as they come across. The fathers and big brothers are absent from such familyparties, however, having been driven away by the females as soon as the young were born,* and now rambling far away through the woods in search of adventures.

In a similar way young weasels and minks are now beginning to move about with their mothers and take lessons in the predatory arts of which their parents

* See my Wild Neighbors (New York, IS97), chap. i. 
are masters. This is by no means pleasing to the birds or to the fraternity of mice, for the weasels and their sharptoothed kin prowl day and night, in June, in search of nests-especially those cor. taining young birds. Watching with keen eyes, and sniffing with sensitive noses, they steal through the grass, or creep lithe and still along the branches, trying to surprise the little mother brooding over her treasures. Failing in that, the marauder may, at least, hope to rifle the nest of its eggs or its young-either will be welcome.

The red squirrels are also addicted to this, proving a dreadful scourge to the birds where they are plentiful; and such nests as those of the oriole and vireo, which are beyond their reach, are liable to be rifled by crows and blue jays, so that all is not peace among the birds in this sweet June weather.

Such "small deer" as field-mice and rabbits have got one family out of the way, and are preparing for a second; but the beautiful spotted fawns of the real deer are finding the use of their slender legs, and learning lessons in woodcraft as they timidly follow the does to the feeding-places, while the red bucks are hiding away, with aching brows, for their new antlers are now sprouting " in the velvet."

June's fishes do not differ greatly from those of May. Young of some kinds be- 
gin to appear, and others are spawning - such as perch and sunfish-in the more northerly ponds and streams. The fishing for the short-nosed sturgeon ("Albany beef") begins the latter part of the month in the Hudson, after the shad-fishing is done with.

In the bays along the coast small flounders attract indolent anglers. The best fishing of the month, however, is for sheepshead, which now enter the shallow sounds and harbors, where they will remain until autumn.

The black-nosed dace are nesting and guarding their nests in the shallow edges of clear streams and ponds with jealous care; and they are all in their rosy nuptial dress. How intelligently they arrange this matter is well told in The American Naturalist for I879, by Dr. W. H. Gregg, of Elmira, N. Y.:

"In the early part of June, I878, an excellent opportunity offered itself for observing the breeding-habits of the dace. Standing one afternoon upon one of the bridges of the river in this city, a nest of this fish was discovered in the stream below; it was about two feet in diameter, situated in running water from twelve to fifteen inches deep, and protected upon the upper side by a small root, by which the current of the water was broken. The female would pass over the pebbles and deposit her spawn, while the male stood ready for an attack, and on the ap- 
proach of an enemy would dart off like a flash in pursuit of the intruder.

"When no danger was near, and after the bed had been covered with spawn, the female would stand sentry until the male had passed over the eggs, and then both would proceed up the stream from four to ten feet or more, and taking a small pebble in their mouths would quickly return and deposit them on the fecundated eggs. Sometimes but one fish would go for pebbles, the other lingering near. Thus layer. after layer of impregnated eggs and pebbles were deposited, one upon the other. . . The covering of the eggs retained them in their place, and at the same time protected them from being destroyed by other fishes, who were constantly hovering about, like vultures, watching an opportunity to devour them, while the interstices between the pebbles gave sufficient space to harbor the little fry as soon as hatched."

June is the time when the bull-heads or smaller catfish of our ponds and streams deposit their ova. This they do in tunnel-like holes in the mud, as long as one's arm, having a chamber at the interior end in which the glutinous mass of eggs is laid, and where they are carefully guarded by the mother for a month or so, until they hatch, and she is able to lead the brood forth and teach them the ways of their world.

Another breeding-fish of this season is 
the gar-pike of our rivers. "These fish are nocturnal in their habits, and in the nights of the last of May and the first of June they approach the shallow water in large numbers for the purpose of laying their eggs. These eggs are covered with a very sticky envelope of complicated structure, which immediately adheres to any object with which it is brought in contact. In its development it is much like the bony fishes. When it hatches from the egg it has a very large mouth with a row of suckers above. By the aid of these it attaches itself to submerged stones. Now the fins begin to appear, and in the space of two or three weeks the suckers disappear, and the young gar-pike swims freely."

Salamanders are casting their skins, and having acquired new ones are leaving the water for dry land, whenever that is their habit.

The tortoises are laying eggs. "In a swamp near my home," notes Dr. Mearns, of Highland Falls, N. Y., referring to the speckled tortoise, "on June I $3,188_{3}$, I found a nest containing three eggs, which were white, equally rounded at both ends, and measured, respectively, I.35x.70; 1.29x.68; I.31 x.68 inches. The eggs were placed in mossy turf on a stone in a bog. A small shallow excavation had been made by the parent, and the eggs were covered after oviposition." 
The snapping-turtle's eggs may also be found at this time, buried in soil, often in ploughed fields; and those of the spotted mud-turtle. "Seldom seen away from the water," notes J. A. Allen, "except when about to lay its eggs, which I have observed it doing [in western Massachusetts] during the second and third weeks of June."

Thoreau paid a great deal of attention to the breeding-habits of the tortoises of New England, and his writings contain very full and interesting descriptions of their methods of burrowing, placing and concealing their eggs. He gives the following dates for Concord, Mass.: Painted turtle, June 6 th, Ioth, I2th, I 8 th; boxtortoise, June 6 th, I6th; striated, or scaled turtle, June IIth, I2th; snapping-turtle, June 7 th; and remarks, under June 12 th, "turtles fairly and generally begin to lay"; and that the skunk is the most persistent of their enemies, digging up and devouring their eggs in great numbers.

Lizards are breeding, too. The pinelizard of New Jersey, for example, is said by Abbott to lay its eggs there in the first week of this month, which are described as long, elliptical, and leathery; and "deposited in conical pits, one egg. the lowermost, being in the bottom, then three above it and four in the third tier." In the same State one may seek for the eggs of the milk-snake, searching mossy tussocks in the meadows in haying-time, 
and for those of the hognose and the pine-snake. Garter-snakes are shedding their hides.

Among smaller life, now, the snails are worthy of attention. Their method of egg-laying is thus described by Dr. W. G. Binney:

"In the course of the months of May or June, earlier or later, according to the locality, and as the season is more or less warm, they begin to lay their eggs. These are deposited, to the number of from thirty to fifty, and even more, in the moist and light mould, sheltered from the sun's rays by leaves, or at the side of logs and stones, without any order, and slightly agglutinated together. The depth of the deposit is usually measured by the extreme length of the animal, which thrusts its head and body into the soil to the utmost extent, while the shell remains at the surface; but sometimes the animal burrows three or four inches deep before making the deposit, in order to insure a sufficiently moist position. Three or four such deposits, and sometimes more, are made by one animal during the summer and autumn. The embryo animal, with its shell, is observable in the albuminous fluid in a few days after the eggs are laid. Its exclusion takes place, under ordinary circumstances, in from twenty to thirty days, according to the state of the atmosphere. . . The hatching of eggs laid late in the autumn is often interrupted 
by the approach of cold weather and of snow, and delayed until the next spring.

In the salt water oysters and clams begin spawning; and the larval young of lobsters, crabs, and many lesser crustacea and worms crowd the surface water, while the starfish come towards the shore to breed, and grow numerous and destructive on the oyster-beds.

Many of the flowers generally accredited to June begin to blossom in May, such as the azaleas, potentillas, and huckleberries. Although it is called the month of roses, and though many of that family do bloom during this month, such as the dog roses, the delicate yellow flowers of the cinquefoil, and the banks of snowy bloom where the crinkled white flowers of the blackberries conceal their wicked thorns, still June is peculiar for the number of orders of plants in blossom.

A few orchids, arethusa, for instance, and the magnificent white and purple lady's slipper can be found; but in looking over a list of June blooming plants, the number of flowers with wax-like petals is noticeable; especially are there. many species of the heather tribe. When the odor of the richly scented white azaleas comes floating over the swamps, mingled with the lemon-like fragrance of the wild grape, and one discovers the white bells of pyrola,wintergreens, and the ghostly Indian pipe growing in the same bit of woodland, and then goes down to 
the pond and sees the lilies floating lazily in the black water, even the most careless loiterer cannot avoid noticing the waxiness of many of the flowers.

On the hills, too, he finds hedges whitened with masses of laurel and the closely set bells of the huckleberries. The graceful tassels of milkweed, purple-tinted, droop in fence corners; and copses, here and there, are covered by the trailing vines of bittersweet, studded with small, thick flowers. The swamps are gay now - first with the brilliant painted cup, then with blue flags, and later with dainty grass-pinks and adder's mouth. But go where you will, you will find flowers underfoot to please the eye, as overhead the woodland music everywhere delights the ear. 


\section{CALENDAR FOR JUNE}

\section{MAMMALS}

Young of most mammals out and wandering about with the mother.

Porcufines.-Common near ponds, feeding on aquatic plants at night.

Mice.-Preparing for second broods.

Flying Squirrel.-The northern (var. hudsonius) form is breeding.

Squirrels.-Males separated from females and their suckling young.

Dier.-Bucks retired to nurse their sprouting antlers.

Pumas and Wild-cats. - Males hunting alone; females teaching kittens.

\section{BIRDS}

Second broods of many early birds.

Mourning Dove.-Nests second week; trees. Yellow-billed Cuckoo.-Nests second week; low trees.

Whippoorwill.-Nests first week, on ground. Kingbird.-Nests first week; orchard trees. Great-crested Flycatcher.-Nests first week; broken stumps and tree-cavities.

Wood Pervee. - Nests first week; orchard trees, etc.

Acadian Flycatcher.-Nests first week; forest trees.

Least Flycatcher, or Chebec. - Nests first week; bushes.

Orchard Oriole. -Nests first week; orchard trees. 
Goldfinch.-Nests third week: bushes and trees.

Yellow-zinged Sparrow.-Nests first week; on ground.

Rose-breasted Grosbcak.-Nests first week; trees.

Indigo-bird.-Nests first week; bushes.

Scarlet Tanager.-Nests first week; trees.

Rough-winged Swallow.-Nests first week; holes in river-banks, bridge-piers, etc.

Cedar Waxwing, or Cherry-bird.-Nests late ; orchards and cedar-trees.

Warbling Vireo.-Nests first week; trees.

Yellozv-throated Vireo. - Nests first week; trees.

Nashville Warbler.-Nests first week, on or near the ground.

Golden-zuinged IVarbler. - Nests second week, on the ground in swampy woods.

Kentucky' Warbler.-Nests second week, on the ground in the woods,

Worm-eating Warbler. - Nests first week, on the ground in the woods.

Blue-winged Yellow Warbler-Dests first week, on the ground in the woods.

Chestnut-sided W Vurbler.-Nests first week; bushes.

Parula, or Blue Yellow-backed Warbler.Nests second week, in hanging moss on forest trees.

Yellow Warbler, or Summer Yellow-bird.Nests first week, in garden bushes and roadside maples.

Black-throuted Blue Warbler. - Nests (northerly) first week, in a bush close to the ground.

Carulean Warbler. - Nests second week, in the fork of a small tree. 
Prairie Warbler. - Nests first week, in bushes and low trees.

Louisiana, or Large-billed Water Thrush.

-Nests second week, on the ground in the woods.

Redstart.-Nests first week; orchard trees.

Irarsh Wrens. - Nests second week; reeds.

\section{BATRACHIANS AND REPTILES}

Salumanders. - Are casting their skins.

Tadpoles of all the smaller Frogs. - Complete their transformation and begin to come ashore.

Toals.-Young, very dark in color, begin to be seen in gardens, etc.

Frogrs.-Generally cease their crying.

Bull-frogs.-Are spawning.

Milk-snake-Laying eggs in meadow-tussocks.

Pine Lizard.-Laying its eggs in the ground.

Painted Turtle.-Lays its eggs in loose soil.

Speckled Tortoise.-Lays its eggs in swamps.

Box Tortoise, or Striated Turtle.-Breeding.

Snapping-turtle._Laying eggs in dry soil.

\section{FISHES}

Sturgeous.-Ascending the rivers.

Gar-pike.-Breeding in lakes and rivers.

Bull-pouts.-Hiding ova in holes and secret places.

Sand-smeits.-Spawning in the eel-grass.

Pickerel.-Spawning in grassy shallows of ponds.

Spanish Mackerel. - Appear on northern coast.

Swordfish.-Arrive early in the month.

Sheepshead.-Arrive in coast bays. 
Scup. - Spawning in the eel-grass.

Perch and their Kin. - Breeding in fresh waters.

Rock Bass.-Surf-fishing begins.

Tautog.-Spawning along rocky shores.

Cunners. - Begin spawning in shallow waters, on their feeding-grounds.

Oysters and Clams. - Begin to spawn.

Squids. - Begin to hatch from the eggs.

Soft-shelled Crabs, -Come to market.

\section{INSECTS}

Yillow-Jackets, Hornets, and Brown Waps. -Workers appear ; assist in feeding young, enlarging nests, and similar duties.

Bumble-bies.-Workers appear, and largely relieve the queen of the care of the young and the provisioning of the nests.

MIud-wasps and Digger IVasps, - Many species on the wing, visiting sorrel and other blossoms.

Ants.-Abundant everywhere; formicaries in full activity; rearing young, collecting food, enlarging nests, and caring for aphides, continuing these activities throughout the summer.

Ichneumon-fies. - Many species and individuals in fields and woods everywhere, searching for victims in which to lay eggs; visiting many sorts of flowers to sip the nectar.

Currant Worms - Larva mature and go to ground, where, under such shelter as they may find, they spin tough oval cocoons.

Tiger Beetles. - Adults abundant in sandy places and along roadsides; larvæ in burrows in gardens and foot paths.

Ground Beetles.-Adults of many species 
abundant under boards in moist places, and wandering over surface of ground; continuing to be found throughout the summer.

Whirligig Beetles. - Adults common on surface of ponds and pools; continue so for the rest of the season.

Ladybird Beetles.-Adults and larvæ common on trees and other plants; larvæ of tenest found among colonies of aphides.

Click Beetles.-Adults abundant, freely visiting many shallow flowers, like raspberry, feeding on the nectar.

Buprestid Beetles. - Adults flying in sunshine on hot days; continuing through July and more or less of August.

Checkered Beetles (Cleridæ).-Adults visiting wild roses and other flowers to feed upon the pollen.

May Bettles, or "June Bugs."-Adults still present, laying eggs about the roots of grasses.

Goldsmith Beetle.-Adults occasionally to be found; flying at night.

Rose Chafers. - Abundant, eating petals of wild rose as well as many other Howers.

Long-horned Beetles.-Adults of some species develop from pupæ.

Leaf Beetles.-Larvæ of many species eating leaves of various plants.

Crane Flies. - Adults more common than in May.

House Flies. - Increase in numbers; continue breeding in refuse-piles.

Robber Flies. - Adults flying in fields and along roadsides.

Bee-flies.-Commonly visiting many flowers.

Syrphid-fies. - Adults of many species abundant about flowers. 
The Monarch Butterfy'.-Adults flying, probably migrating northward.

Regal Fritillary, or Idalia Butterfy.-Larvæ developing on violet leaves and changing to chrysalids.

Great-spansisled Fritillary, or Cybele Butter. fy._-Adults come from chrysalids during latter part of the month.

Mountain Silver Spot, or Atlantis Butterfy. -Adults appear, especially in latter part of the month, fresh from the chrysalis.

The Baltimore, or Phaton Butterfly. - Adults come from chrysalids; to be found only locally and in swamps; remain on the wing a month.

Violet-tip Butterffy. - Caterpillars developing; feeding on foliage of hop and elm.

Gray Comma, or Progne Butterfly.-Larvæ develop upon currant and wild gooseberry plants, and change to chrysalids.

Hop Merchant, or Comma Butterfly. - Caterpillars feeding on leaves of hop and eim, changing to chrysalids during the latter part of the month.

Red Admiral Butterfy. - Larvæ feeding in folded nettle leaves.

Painted Beauty Butterfy'. - Butterflies on the wing, ovipositing on everlasting (Graphalium).

Red-spotted Purple Butterfy. - Adults appear, becoming more abundant towards the end of the month.

The Viceroy Butterfy. - Adults emerge from chrysalids and fly over fields and along roadsides.

Imported Cabbase Butterfy. - Adults still flying; larvæ feeding on cabbage leaves.

Tiger Sivallowtail.-Adults come from hibernating chrysalicls, visiting flowers of clover 
and other plants, and ovipositing on leaves of birch, poplar, and other trees.

Black Sivallowtail, or Asterias Buttirfly.Adults flying over fields and gardens, ovipositing on carrots, parsnips, and other members of the parsley family.

Green-clouded Swallowtail.-Butterflies continue on the wing; females oviposit upon leaves of spice-bush and sassafras.

Tent Caterpillar. - I arvæ mature and spin cocoons.

Cecropia, Luna, Promethea, and Polyphemus Moths. - Adults come from cocoons and lay eggs upon various trees.

Humming-bird Moths (Hemaris). - Adults fly in bright sunshine, visiting Iris and other blossoms.

Sphinx Moths. - Adults of many species appear.

Cutworm Moths. - Adults of many species appear, flying to light at night.

Canker-worms. - Larvæ mature and go into soil to pupate.

Chemy Tent-maker. - Larvæ pupate in a mass at centre of tent; later pupæ work their way out to edge of tents to disclose the ochre yellow moths.

Leaf-miners. - Larvæ of many species developing in leaves.

Caldis-fies. - Adults of some species appear.

Hellgrammites. - Pupæ under logs mature into adults.

Tree-hoppers.-Young developing on various plants.

Leaf-hoppers. - New brood of adults.

Scale Insects.-Young fix themselves on leaf or bark and suck the sap of the food-plant. 
Plant-lice, or Aphides.-Continue to multiply rapidly; many species migrate from trees to herbaceous plants.

Common Locusts. - Young develop gradually, feeding upon grasses and clovers.

Katydids. - Young wandering over various plants, sometimes eating petals of wild rose.

Tree Crickets. - Young wander over branches, searching for aphides, upon which they feed.

Black Crickets. - Young become common in shelter of grass and grain.

Dragon-fies. - Adults of many species on the wing, especially near ponds.

May-fies.-Adults abundant, especially early in the month. 


\section{J U LY}

"The earth is warm again, the air is filled with odors, The lanes lined with gay flowers, which nod and bend To every passing breeze." 


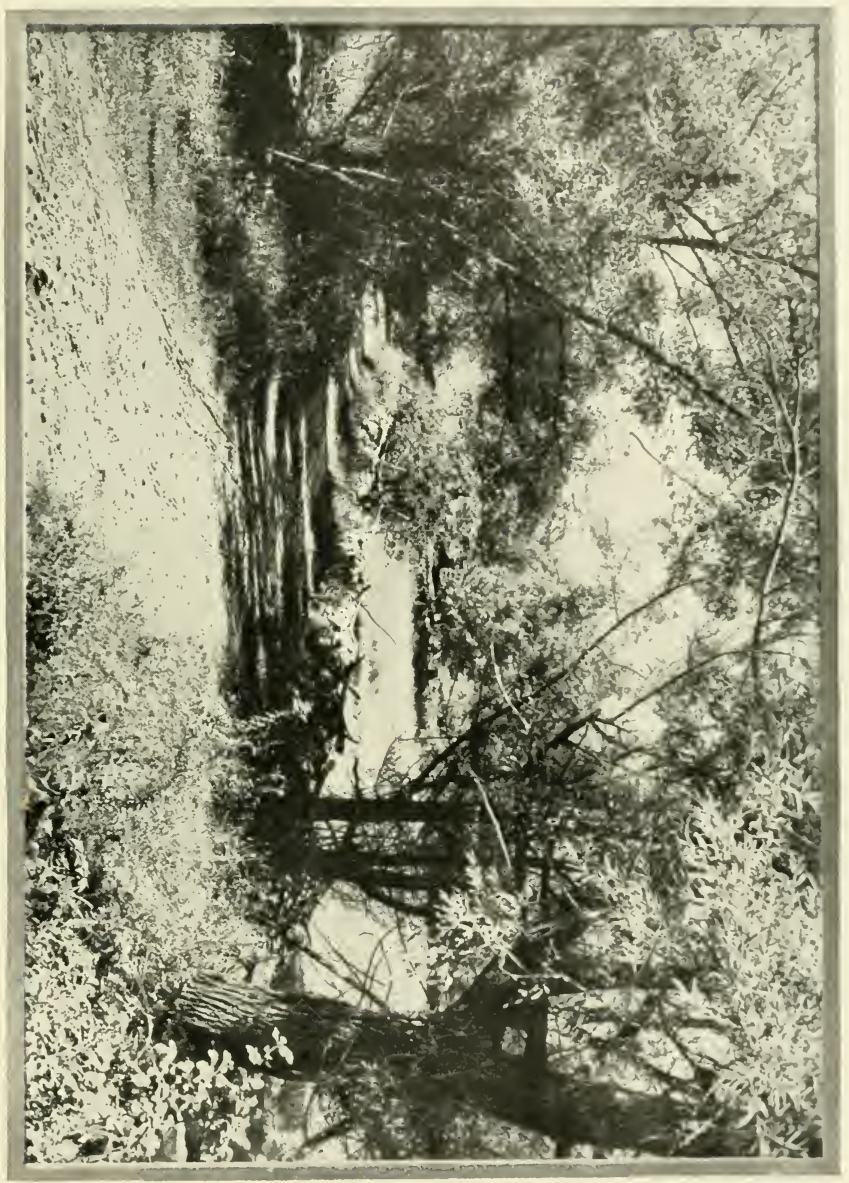





\section{JULY}

IT is by no means easy to separate July from August in such a series as this and say this feature belongs to this month and that one to that. Midsummer brings us to a certain pause in the progress of the year-not to the full stop of midwinter, but to a time when nature is growing and waits for results. Therefore I can treat midsummer much as I did midwinter, as a period, considering July and August together, but under two aspects, first inland and second at the seashore, whither many of my readers doubtless will betake themselves during the long vacation.

By the time July is well started the rains have ceased, the woods are deep in the shadow of completed leafage and growing twigs, the soil is dry and is throwing out an increasing crop of curious agarics, and walking in the dusty roads or open uplands is unpleasant. Naturally enough, then, we turn in our rambles towards the watercourses and seek to read the "books in the running brooks."

"The shimmering fields, where haying has begun, no longer resound to the merry music of the bobolink, meadow- 
lark, and sparrow; the heated woods are silent, and we say that the birds are too languid to sing in this close and torrid air. That is partly true, no doubt, but the main reason for the silence of this noontime of the year is that the season of nesting is done with, the musicians no longer are inspired by the eagerness of courtship, but are away by themselves in selfish freedom, or else are busy in helping the little mothers to guide and guard the young.

By August the singing of birds has almost altogether ceased, and we hear only in the early morning or at evening feeble reminders of the brilliant notes of May and June. Excepting the friends that trustfully inhabit our gardens, we see few birds unless we loiter by shady brooks, while the mammals-always shy of exhibiting themselves-keep more out of sight now than ever, save such familiar ones as the warmth-loving woodchucks and squirrels of the East, and the always lively gophers and ground squirrels of the West. Let us not forget, however, that on moonlit nights, as harvest-time approaches and the evening chiming of the veery fades from our reluctant ears, the raccoons, muskrats, and big squirrels by twos and threes are slyly studying the progress of the cornfields, and presently are fattening on the milky ears.

This hot, dry, sunny weather, however, is the heyday of insect life. Lie 
down in the long grass some time and note how many minute-winged and creeping creatures you can find in five minutes. Search the rough bark of an old tree and catalogue the small life it harbors. Observe as summer advances how active and industrious are the ants, and how everywhere the spiders are embroidering their silken lace upon the grasses and leaves and old woodwork. And wherever you go, along the dusty highway, across the meadows, about the garden or through the woods, how an almost innumerable company of butterflies dance before your steps or rise and dip and curvette in the bright air about your head, while at night the moths flock to your lighted windows, equally delicate but less gay of hue, as befits a being whose life is mainly passed in darkness.

Butterflies are the characteristic of midsummer :

... "pretty genii of the flow'rs,

Daintily fed with honey and pure dew."

That is nearer the truth than the poets sometimes get in their zoology, for the butterflies feed only by pumping up the honeyed moisture held in the cups of the flowers, or by the juices from various rotting substances upon which some of the less dainty of them feed. Most of them have but a brief summer of life, seeking with an inborn knowledge that is one of 
the most wonderful examples of real instinct (a much-abused word) the proper plant upon which to deposit their eggsproper because that plant alone will furnish the right nourishment for the caterpillar that later, after these butterflies are dead, will hatch out of their eggs and begin to feed.

No summer study is more delightful than that of these "emblems of the soul," whose forms and colurs and attitudes are alike lovely; and if you are in possession of such a guide as the admirable books of Mr. Samuel E. Scudder, or of Mr. W. J. Holland, whose colored plates enable you to identify any species likely to be met with in your rambles, you have the means of great happiness in your hands.

Unlike the comparatively dull-hued butterflies of early spring, those of summer are gay in raiment. This seasonal conformity between the butterflies and their surroundings has been worked out in a discerning and interesting manner by Mr. Scudder as follows:

"I do not know that any of our naturalists or artists have written of the harmony between the prevailing tints of a New England landscape at different times of the year and of the insect world at the same seasons. Our common butterflies, which nature has been at such pains to adorn, show a shifting panorama of form and color from early spring to the time of frost. 
"First, in the sombre, leafless woods, come the various dusky wings, brown and black, tripping softly in and out among the gray rocks and over the dry fields and dark pools of melting snow, or sunning themselves on dry sticks ath wart the sun. Hard upon these, in the time of early violets and hepaticas, and frequenting the spots loved by them. follow the little blue butterflies scarce larger than the flowers. Then, as spring fairly bursts upon us with its fresh and varied hues, come crowds of queenly swallowtails, lustrous with metallic gleam, or striped and belted with gay colors, and the banded and spotted purples that court the quiet forest road and the brink of the mountain brook; the soft, white butterflies, that look too pure for earth, less retiring than the last, float about our gardens, alas! on sad intent, while the brisk little tawny and black skippers everywhere bustle and whisk about.

"Summer, with blazing sun and diversified blossoms, brings us the hot-looking coppers, and all that dappled band of fritillaries and angle wings, blocked in red and black above, and often variegated by odd dashes and spots of burnished silver, or by peacock eyes beneath. How they crowd about the thistle, spreading thistle blossoms, or on the many-flowered umbels of the milkweed, and fan themselves with content at their sweet lot!"

The roadsides are yellow with mullein 
July 10 and foxglove as we take our way down to the creek, in whose pools the white lilies are now in bloon, floating unharmed, the perfection of purity, upon the dark water. As we sit quietly down upon the bank our ears are filled with that hum of insect life which is the voice of midsummer, and a pair of syrphus-flies poise on invisible wings just before our eyes, gleaming as if truly made of polished gold; and look at that gem hovering over the snowy lilies-a hummingbird that whirrs from flower to flower, picking out of their waxen chalices the minute morsels of his insect fare.

What beauty rises from the dark mud of this weedy pool-rosy lilies, the dancing snowflakes of the water ranunculus, heart leaf, yellow cups of other lilies and buttercups, the rich violet purple of the water hyacinth, or pontederia, and alongshore, prince of all the pond-side, the tall, scarlet spikes of the cardinal flower. Here and there over the smooth surface dart and glide the skaters, and, over all, zigzag innumerable dragon-flies, throwing metallic reflections, blue, red, green, and bronze from their burnished armor and gauzy wings.

Creeping about among the floating leaves and slimy weeds are several sorts of delicate spiral snails, the limneids, and others made in a flat coil, the planorbids, which are easily gathered, and whose shells, after the animals have been boiled 
out, make very pretty objects for a cabinet, for they exist in great variety and with elegant markings. These, living in still waters, are very fragile, but in rapid streams, especially of the southern Alleghenian region, where limestone rocks are common, may be gathered scores of different kinds of spiral snails, called melanians, which are thick - shelled, and often nost curiously knobbed and sculptured. All are vegetable feeders, rasping off the surfaces of plants for food, and cleaning the stones of the minute green "moss" which gathers upon them where the current is not too swift; and they are in their turn eaten by fishes, turtles, and water-birds, though some of the angular melanians must be pretty hard either to crush or swallow.

Though these live in the water they breathe air, and have a lung-like arrangement similar to that of the land snails. These latter are hard to find during the dry, hot, midsummer weather, because this affects them almost as much as does the cold of January, causing them to hide in some damp and shady retreat, and go into a sort of drought torpor, called æstivation. To effect this they form a drumhead of hardened slime across the opening of the shell, just as we saw them doing in hibernation, and remain quiet until autumn, except when a long rain induces them to venture forth.

Another sort of mollusk, represented by very few species north of Pennsyl- 
vania, but found in great variety in all southern and western waters, is the river mussel. These are bivalves-real freshwater clams-and they breathe, like the fishes, by means of the curtain-like gills hanging just beneath the two halves of the shell. Some are no larger than half a dollar, while others grow to the size of a big man's palm; some are thin, light, and flattened, others heavy, robust, and almost globular; a few show curved or radiating colors on a smooth, shining surface; more are dark and scaly, while many are ornamented with ridges, or knobs, or both, and nearly all have a lovely mother-of - pearl interior, where valuable pearls are often formed. These mollusks stand on the blade edge of their wedge-like forms, half-buried in the sand (for they do not like real mud), and move slowly about, leaving tracks like sinuous furrows, by reaching out a muscular "foot," gripping the ground, and dragging the body forward. They suck in a constant stream of water, which brings to their digestive organs minute particles of floating food, animalcules, plant spores, etc., and at the same time furnishes oxygen to the blood circulating through the gills. A cabinet of their shells is well worth having; and ready-made collections may often be found where muskrats and raccoons are common, for both these animals delight to eat their flesh and leave the shells on the bank. 
The early days of July are an excellent time to study the fresh-water fishes, especially the little fellows that belong to the brooks and mill-ponds-minnows, shiners, sunfish, perch, bull-heads, and the like. Of these the "pumpkin seeds," or sunfish, are more or less known to every fishing school-boy, and he will tell you that they are sharp-witted and lively, feed on insects and worms, and build nests.

"To see our common sunfish at their best," writes Dr. C. C. Abbott, " it is necessary to hunt up their nests in May. ... One of the 'sights' of this time, if we direct our-steps to the creek, is the row of sunfish nests along the shore. These fish at that time have a horror of dirt, and every speck other than fine, clean sand is carefully removed from the shallow circular depressions which constitute their nests. ... In these nests both fishes will often be, and yet scarcely recognizable from above. All the gorgeous coloring is confined to their sides and bellies; the back, being a dull green, blends well with the surroundings and the color of the water. . . The nests are usually occupied for the space of four weeks, when the parent fishes relinquish their care and leave the young sunnies, now more like flakes of jelly than bony fishes, to shift for themselves."

Some of the smaller ones are darters -dusky fingerlings that rest motionless on the sand. If anything startles them 
they scramble out of sight beneath sonie flat stone with astonishing quickness. The sand perch is the one best known. Closely resembling the bottom on which they rest upon leg-like fins, the darters wait till something good to eat comes within reach, when they catch it by a queer wriggling leap. Two or three strokes are all they can do at a time in the way of swimming. They are great egg-thiefs, and the perch is an especial sufferer from them.

The various perches are found everywhere, and are among the most active and interesting fishes for an aquarium, where alone the habits of these small fishes can be studied to advantage. "Climbing weeds, burrowing in the sand, perched on stones, or cracking the shell of some unlucky snail against the glass side of their prison, they seem possessed of more than fishy knowledge."

These perches and their relatives, such as the rock or striped bass, are like the weasels on shore in their fierce pursuit of the smaller fishes that form their subsistence. Those that suffer most are the minnows, or cyprinoids, which are eaters of minute crustaceans, insects, snails, etc., together with much plant food, and are of social habits. Many of them are exceedingly pretty, especially in spring, when their silvery scales often glow with brilliant tints. To this family belong the dace, the chubs, and in fact the greater number of the "shiners" of our brooks and ditches. 
Some of them make beds in the sand of clear streams, or even regular nests of pebbles in which to deposit their eggs, and they stay by them and watch them against danger as well as they can. I think none, however, care so much for their young as do those very different, ugly, worm-eating, mud-loving fishes the horned pouts, or bull-heads, which now keep their little ones in a close flock, the mother swimming round and round them to guard them from harm, and betraying the greatest anxiety when anything threatens the peace of her young.

Several sea-fishes postpone their spawning until this month. Such are the Spanish mackerel, which arrive from the South and begin spawning in the open bays, while the sea-bass resort to the eelgrass. The goose-fish now spawns, voiding its eggs in the form of broad floating ribbons. The sea-robins, gurnards, and sculpins are also spawning, and the queer pipe-fishes in the eel-grass. The kingfish and harvest-fish are added to the market list, and the netting of sturgeon begins in the Hudson. Crabs are shedding their coats, and the toothsome "soft-shell". is a dainty of the season; while the surface of inshore waters is alive with its larvæ.

Marine life is now abundant and active. Jelly-fish are beginning to grow numerous, annelids are laying eggs, and the planarians attaching theirs in large white clusters to submerged rocks and wood- 
work, among the crowding ascidians and hydroids. Oysters and clams are spawning vigorously, and the starfish leaving their beds for deep water; while the squids are spreading now, on gravelly or shelly bottoms, "eggs contained in large bunches or groups of long gelatinous capsules."

In July are produced the young of several snakes and lizards, those of the pine-tree lizard regularly appearing in southern New Jersey during the second week of the month. Eggs of the hognose, the pine-snake, and the milk-snake may also be found now ; and it appears probable that the black-snake lays its eggs this month, burying them in rotting vegetation, barn-yard manure, and similar warm places. Of this, however, nobody is yet certain, for "when the sexes [of Bascanion constrictor] unite, when the eggs are laid, how concealed, and when they hatch are," says Mr. O. P. Hay, of the National Museum, "some of the things we need to learn." It is stated of this serpent's near relative, the redheaded, or mountain black-snake (Coluber obsoletus), that near Washington it lays its eggs in April (once, at least, in a hollow stump), and that they hatch the same month. Towards the end of the month young garter snakes may sometimes be found in northerly places, and now and then an infant water-snake, but as a rule the birth of these is delayed until September. 


\section{CALENDAR FOR JULY}

\section{MAMMALS}

Second broods of various small rodentshares, squirrels, and mice.

\section{BIRDS}

Bay-birls.-Begin to arrive from North.

Tree Swallowos. - Begin flocking on the marshes, preparatory to migration.

Cedar-birl.-Laying eggs in orchard nest.

Goldfinch.-Often now laying first eggs.

Second broods of various species.

\section{BATRACHIANS AND REPTILES}

Pine-tree Lizard.-Eggs hatching last fortnight.

Hognose Snakes (Heterodon). - Eggs laid.

Pine-snake.-Eggs laid, in dry earth.

Milk-snake._Eggs laid, in rotting vegetation, etc.

Black-snake.-Eggs probably laid now, in decaying stumps, etc.

Garter-snakes.-Young begin to appear.

\section{FISHES}

Goose-fish.-Spawning in the open sea.

Spanish Mackerel. - Arrive and spawn in bays.

Sea-bass.-Begin spawning in the eel-grass.

Sculpins, Sea-robins, etc.-Are spawning.

Toad-fish.-Young begin to appear late.

Pipe-fishes.-Spawning in the eel-grass. 


\section{INSECTS}

Hornets and Wasps.-Colonies increasing rapidly in numbers; workers caring for young and enlarging nests; visiting colonies of aphides for " honey-dew," and flowers for nectar, or to catch insects.

Bumble-bees. - Workers, large and small, abundant; visiting blossoms of raspberry, partridge-berry, and many other plants.

Leaf-cutter Bees (Megachile).-Common; visiting self-heal and many other flowers; cutting out pieces of leaf-blades of various plants for use in making nests for young.

AIud-avasps. - Many species at work; visiting flowers of parsnip and other plants; making cells and storing them with spiders, grasshoppers, etc., as food for the young.

Eumenes.-These and other mason-wasps visiting blossoms of sumach and other flowers; constructing their mud-cells and provisioning them with caterpillars and other insects.

Ichneumon-fies.-Many species, large and small, visiting blossoms of wild parsnip, fireweed, and many other flowers to sip nectar : searching foliage and branches for caterpillars in which to deposit eggs.

Currant Worms. - Some pupe mature into saw-flies that lay eggs for a second brood.

Tiger Beetles. - Adults of various species abundant in sandy places, along beaches, in barren fields, along paths and roadsides; continue through August.

Ladybird Beetles.-Increasingly abundant; larve, pupæ, and adults all to be found in suitable localities.

Click Beetles. -Adults to be found about Howers, and larvæ (wire-worms) in the soil. 
Red Milk-weed Beetles.-Abundant on milkweed.

Long-horned Beetles.-Adults often seen.

Leaf Beetles. - In double-brooded species; adults of new brood appear.

Green Dogbane Bectle.-Abundant on dogbane.

House Flies.-Increasing in abundance because of the new broods constantly developing, continuing to increase through August.

Robber Flies.-Nore abundant than in June; continuing through August.

Syrphid Flies. - Adults abundant about bright flowers; larvæ among colonies of aphides.

Monarch Butterfy. - Larvæ feeding on leaves of milk-weed.

Regal Fritillary, or Idalia Butterfly.-Adults emerge from chrysalids, the males only being found at first.

Great-spangled Fritillary, or Cybele Butterfly. -Adults abundant on milk-weed, dogbane, and other blossoms, continuing on the wing through August.

Silver-spot Fritillary, or Aphrodite Butterfly. -Adults emerge from chrysalids.

Mountain Silver-spot, or Atlantis Butterfly. -Adults abundant, being found especially on blossoms of dogbane and milk-weed.

Baltimore, or Phaton Butterfy.-Eggs laid on Chelone and other plants, and not hatching for about three weeks.

Violet-tip Butterfy.-Adults of the first brood of the season appear and lay eggs for a second brood.

Gray Comma, or Progne Butterfly.-Adults of new brood come from chrysalis and continue 
on wing a month, ovipositing during latter half of this time.

Hop Merchant, or Comma Butterfly.-Adults of new brood come from chrysalids and lay eggs during latter part of month.

Compton Tortoise Butterfly (J-album). - Butterflies flying in open woodlands and along roadsides.

Antiopa, or Mourning Cloak Butterfies.The butterflies of the first summer brood appear about the margins of woods, in open groves, and along highways.

Red Admiral Butterfly.-Adults of the first brood appear.

Painted Beauty Butterfy.-Larvæ feeding on everlasting; some butterflies still abroad.

Painted Lady Butterfy. - Adults of new brood appear during latter half of month and continue on the wing for several weeks.

Red-spotted Purple Butterfy.-Adults still abundant; ovipositing on various willows, birches, and other trees.

I'icerey Butterfy. - Larvæ mature; change to chrysalids and emerge, during latter part of month, as butterflies of the second brood.

Blue-eyed Grayling, or Alupe Butterfly.Adults emerge from chrysalids and fly about in shady situations.

Spring Azure Butterfly. - Adults of the second brood appear along margins of woods and by the roadside. (All of the form neglecta.)

Clouded Sulphur Butterfy.-Adults of second brood appear; abundant everywhere, often congregating in highways about pools of water.

Tiger Swallowtail.-Larvæ develop on birch, poplar, and other trees and change to chrysa- 
lids, some of the latter maturing into butterflies during the latter half of the month.

Green-clouded Swallowtuil.-Larvæ develop in rolled leaves of sassafras and spice bush, and change to chrysalids.

Black-clouded Swallonitail, or Asterias Butterfly.-Larve developing upon carrots and related plants. Some change to chrysalids.

Tent Caterpillars. - Moths of both the Forest Tent Caterpillar and the American Tent Caterpillar flying at night and depositing eggs in rings on twigs of trees.

Cecrofia and other large Moths. - Young larvæ hatch from eggs and begin feeding on their various food-plants.

Humming-bird Moths (Hemaris). - Adults found in bright sunshine visiting various flowers. Sphinx Moths. - Adults commonly visiting long-spurred blossoms at dusk.

Cutzuorm Moths.-Larvæ of summer brood developing in grass-lands.

Caddis-fies. - Adults common in vicinity of ponds and streams.

Cicadas, or Harvest-fies. - Nymphs come from ground and develop into adults, which sing during latter part of the month.

Leaf-hoppers. - Increasingly abundant on grasses and leaves of shrubs and trees.

Common Locusts. - Vany species mature, often in great numbers.

Tree Crickets and Katydids.-Míature and begin singing.

Black Crickets. - Mature and begin singing.

Dragon-fies. - Increasingly abundant in vicinity of ponds and streams.

Damsel Flies.-To be found in great numbers along the margins of ponds. 


\section{A UGUST}

"There is no sound amid the trees, Save the faint brush of rustling breeze;

Save insect sentinels, that still

Prolong their constant 'larum shrill, And answer all, from tree to tree, With one monotonous revelry." 



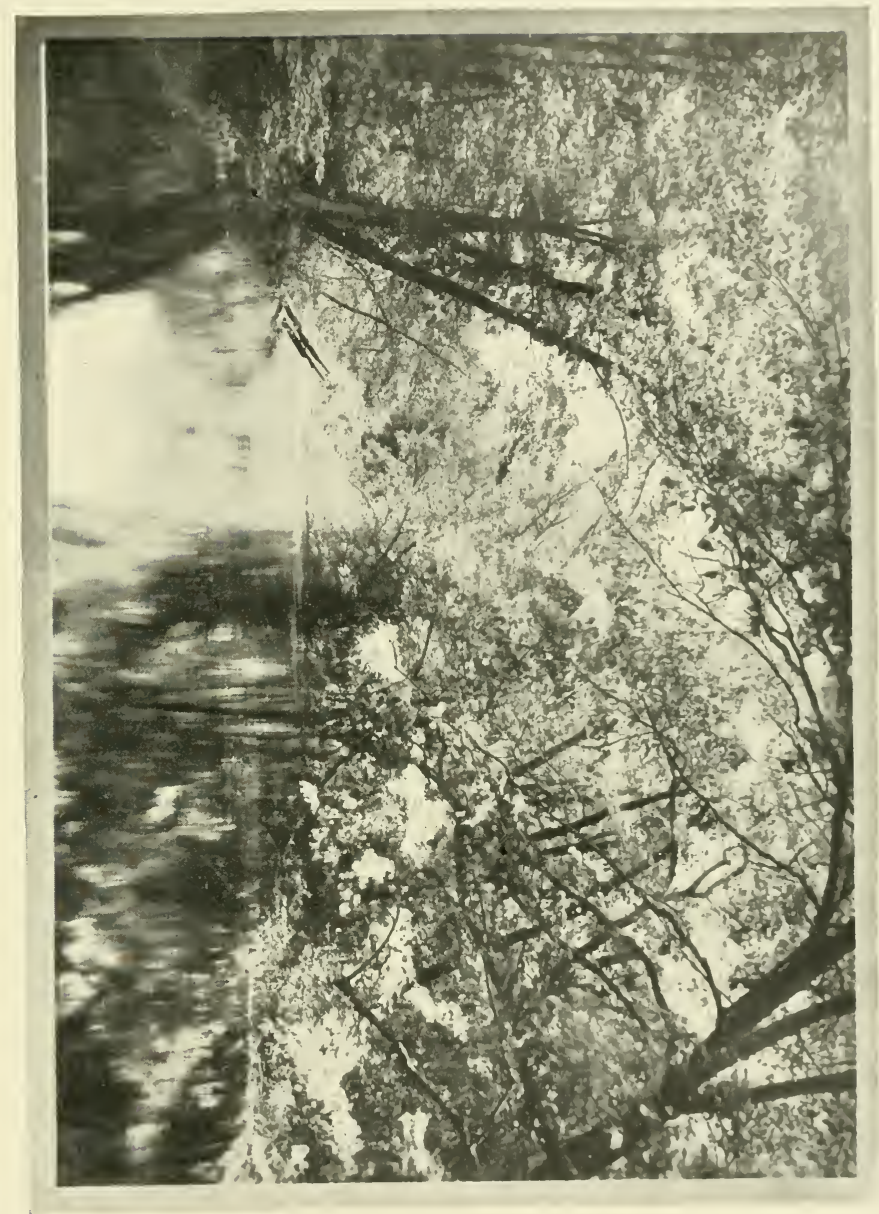




\section{AUGUST}

AUGUST is the month when most persons who can go to the sea-shore do so; August I and it is in this month that inlanders make such studies as they can of maritime natural history, to which this chapter will be particularly devoted.

In the human practice noted above, men, after all, are only imitating their lowlier cousins. In midsummer all the mammals go down to the sea-shore more or. less, especially at night, attracted by the salt and in search of food, and none more commonly than the small carnivora. Down South the wild oysters that grow upon the eel-grass, or even attach themselves to bushes whose roots or branches trail in the tidal creeks, are called 'coon oysters, because that sly mammal is so fond of feeding upon them : and no creature is more fond of "sea food" than the opossum, which hunts about the holes left at low tide for crabs and other delicacies.

Certain large inland birds, as the crows, constantly visit the beaches in midsummer to pick up scraps in the surf, while the fish-hawk and marsh-harrier are regular residents there, the nests of the 
former, repaired from year to year, forming well-known objects of interest in many localities. Half a century ago all our sandy beaches, from Hatteras to the Bay of Fundy, teemed in summer with a screaming multitude of gulls and terns of various species, watching over their villages of nests amid the sand hillockshovering, wheeling, darting, tipping from side to side upon outstretched wings, their snowy plumage glistening alternately against the sky or the sea. This beauty and grace have almost disappeared from all easily accessible shores, and the loss to all lovers of the sea-side is irreparable. But this is not the whole of the loss, for formerly all the marshes and estuaries abounded the year round in water-fowl, wading and sand-running birds that have been killed or frightened away, so that these places are now almost deserted at the season when visitors from inland most come to them.

Certain small birds still enliven the shores, however. Swallows are nowhere more numerous, for they naturally belong to the sea-shore cliffs, and the sterile but grassy shore fields and dune tracts are alive with several sorts of sparrows rarely seen elsewhere-such as the sharp-tailed and "sea-side" finches, the yellow-winged and Savanna "grasshopper" sparrows, all of which are of pallid colors and have weak, prattling voices. Two very characteristic little sprites of the salt marshes 
are the marsh wrens-long-billed and short-billed. They resemble in appearance the ordinary house wrens, cocking up their tails and dashing about with the same air of scolding energy. It is astonishing how numerous they are among the reeds of all the back bays, and while you hear their incessant, powerful, and melodious voices on every side, how difficult it is to get sight of one. By this month, of course, they are long past the breeding-time, but you may find hundreds of their nests still frequently occupred as roosting-places at night by both old and young. They are in the form of large, hollow ball baskets woven of grass, hung to the reeds, and entered by a small door in the side. If there is a bird with more jollity in him than a marsh wren, I don't know his name.

As August wanes into golden September one begins to see many shore-birds that are slowly making their way southward. Upon the grassy downs alongshore, plovers, like the killdee and upland, whirl about and shout out their names; nimble sandpipers go skurrying along the sands wherever you walk, chasing the retreating ripples to their lowest verge, then skipping back out of the way of each advancing wave; and the marshes become noisy with the clucking of various mud-hens and alive with ducks and their kindred. Autumn is the heyday of seaside birds. 
“I heard a katydid last night," writes Abbott, at Trenton, N. J., "the first of those tiresome singers, and, I am told, there will be frost in six weeks. It is certainly appropriate that the frost should begin on so suggestive a date as September 2ist-the day when summer really ends. But August suggests the close of the season in other ways: the gathering of the reed-birds in the marshes, the flocking of the blackbirds, the evening roostward flight of the crows, to say nothing of early asters and golden-rod. among flowers that are now blooming along the dingy, dusty roads. I have noticed all these, and some at a much earlier date than the first faint lisping of a timid katydid; and all such sights and sounds are similarly suggestive-the summer is drawing to its close."

By midsummer all the fishes of the year have appeared on the middle parts of our coast. Sheepshead, scup (or porgy), sea-bass, and tautog have become numerous, to the delight of the anglers, and the salmon are ascending the Maine rivers, while southward the drums, redfish, and others, are prowling about the estuaries and lagoons, and the Spanish mackerel are breeding in the bays, deferring this duty until August in Long Island Sound, and as soon as it is done departing for warmer latitudes. By this time young fishes are crowding all waters. Read Thoreau's long and sympathetic 
account of how he saw the bull-pouts leading their families about guiding and instructing them. Little shad are descending the Hudson and Delaware and other northern rivers to seek their fortune in the great outer world of waters, where young bluefish and mackerel are already becoming common, and are chasing inshore the shoals of "spots" that form the most delicious pan-fish of the season. This is the month, indeed, when those terrors of the sea, the swordfish, bluefish, and squeteague, are most in evidence, and furnish the best sport, rivalled only by the surf-fishing for bass. The bluefish and squeteague are much alikethey feed in the same manner, and come and go at similar dates, yet are rarely seen together, a fact probably due to the circumstance that the bluefish is the swifter, so that he outruns and drives away all the prey instead of sharing it with his slower relative. Hence, the two keep apart, each hunting for its own food at its own pace, but both are dreaded by everything smaller and weaker than they.

But these and all the other predatory surface-feeding fishes find a vast abundance and variety of swimming food at this season in the waters off our New York and southern New England coasts. Whether or not the Gulf Stream is directly felt in the bight between Sandy Hook and Cape Cod, it is certain that the prevailing southerly winds bring warm 


\section{August 6}

water here, and that in late summer and early autumn the surface water around Long Island and thence east ward to Buzzard's Bay is very warm, and a great host of marine invertebrates may be gathered there by the naturalist's dredge and towing-net. This attracts a host of small predacious fishes, and after then come the larger ones, like the swordfish, sharks, and the smaller cetaceans. All these, big and little, are most numerous in the evening and on still nights, when many rise to the surface that in daylight or in storny weather remain in the depths.

Among these free swimmers in the open sea most of the crabs may be seen, and the young of all of them, including the lobster. The larvæ of marine worms are numerous, having a youthful "fling" before settling down to a fixed position in the mud or sand. The same is true of many mollusks.

" Nlost of the higher gastrópods," says Verrill, "enclose their eggs in capsules, which they attach to stones, algæ, or shells, and within these the eggs hatch, and the young have a well-formed shell before they eat their way out of the capsules, and when free they crawl about by means of the 'foot,' like the adult. But in the lower orders of gastropods most of the young, when first hatched, are furnished with vibrating cilia, and swim free, by this means, for a short time. These larvæ are very different from the 
adults, and in the case of the naked mollusks (Nudibranchia) the larva are furnished with a beautiful little glossy spiral shell, which they afterwards lose. The pteropods swim free in all stages. . . .

"The bivalve shells mostly produce minute young, or larvæ, which are at first provided with vibrating cilia, and swim free for several days, as is well known to be the case with the oysters, clams, mussels, tereds, etc. . . . The common fixed ascidians, both simple and compound, mostly produce eggs that hatch into tadpole-shaped young, that swim about for a short time by the undulating motions of the tail, but finally become fixed by the head end, and losing, or rather absorbing, the tail portion, rapidly develop into the ordinary forms of the ascidians."

To this list must be added great numbers of swimming larvæ of starfishes, seaeggs, and other echinoderms, including various holothurians.

The jellyfishes, young and old, now throng the surface waters, and illuminate them with that beautiful phosphoresence of which these and the colonies of wandering hydroids and ascidians, such as the exquisite salpa chains, are mainly the authors. Sometimes in August that marvellously beautiful creature, the Portuguese man-of-war, comes sailing into our harbors from the tropics, its iridescent sail hoisted to catch the gentle wind. 
The jellyfishes, or medusæ, are among the loveliest of living things, having an extremely simple organization, closely allying them to the polyps on one hand and to the echinoderms on the other. They consist of hardly more than films and threads of a glutinous substance, almost unorganized and more or less transparent. and most of them are nourished by microscopic food taken from the sea-water which permeates their substance, though others are carnivorous.

These lambent gems of the sea, softly radiant with the shifting play of their own phosphorescent light, mantling their crystalline bells and lace-like appendages with blushes of submarine lightning, swarm in incredible numbers and diversity in all summer seas. Some are oceanic, and known only where they burst into tiny rockets under the prows of far-sailing ships: but the main body of the tribe frequents the coast, seeking the still, warm water of protected bays and lagoons, and floating like chains of prismatic bubbles -necklaces of pearls on Ocean's breast. But a cloudy or stormy day will send most of them to imperturbable depths, and others avoid the noonday glare.

One of the commonest forms on our beaches in late summer is the great Aurelia, or "sunfish," of which vast shoals are sometimes seen basking on the bosom of the sea, preyed upon by squids, whales, turtles, and some fishes, though well able 
to protect themselves by their stinging powers against small foes; their young are produced in the late spring.

Not all the jellyfishes are umbrellashaped, however. One group, of which our August waters contain many representatives - the ctenophores, or combbearers-are egg-shaped, transparent little creatures, with eight lines of tiny paddles running up and down their sides, that flicker with mysterious light, as if they formed the gossamer frame of some fairy lantern.

The movements of these medusæ express the perfection of beauty in motion. Nothing in nature exceeds the elegance and sinuous grace of their swimming. Unsubstantial shapes of, rather than in, the water, palely drawn against the darkness in ghostly outlines by their own phosphorescence, their trailing tentacles mere ripples of light, they pulsate elegantly onward without visible effort by the alternate contraction and dilation of their flexuous disks, reflecting here a prismatic sunbeam, there altogether lost in shadow, and so throb softly, silently, tracklessly through the liquid-mere passing thoughts in the brain of the Great Deep.

The rambler along the sea-shore in midsummer searching for marine creatures will be rewarded according to the character of the locality. A low sandy beach or offing, such as prevails along the coasts 
of the Southern States, New Jersey, Long Island, and Cape Cod and its outlying islands, is the poorest of all places to look for sea animals or plants, and yet a stroller will find many things to attract his eye. Such beaches slope out very gradually beneath the water in a plain of ever-shifting sand, where few sea-weeds can keep a roothold. Consequently-as marine as well as terrestrial life (apart from fishes) depends upon vegretation - the variety of animal life that can obtain a living upon such a desert is small, and what is there exists mainly by the aid of certain outlying reefs of rocks clothed with submarine plants.

$\mathrm{Up}$ where the high tide or storm waves have left them lie sinuous rows of dead eel-grass and various red sea-weeds, attached to shells and pebbles that have gone adrift; and mixed among these, or scattered over the smoother part of the beach, are the remains of crabs and fishes, shells of mollusks, bits of sponges, and various minor creatures.

Of the sea-urchins one sees none south of the rocky shores of Massachusetts, except the flat sand dollars washed up from deep waters; and starfishes are uncommon south of Sandy Hook, though altogether too numerous all round Long Island, where they increase with the growth of the oyster-beds.

Crabs are of familiar sorts for the most part, but the largest and smallest will interest inlanders. The former is the great

\section{August 15}


horseshoe, or king crab, whose whole body is protected by a scoop - shaped shield, to the rear of which is hinged a bayonet-like tail, by whose aid the creature can hoist himself up so as to force his way down into the sand, or to turn right side up when a wave or a boy upsets him. You will examine him more curiously, perhaps, if I remind you that he is a relic of an otherwise long extinct race of crustaceans that trace their lineage back to the trilobites, the most numerous and important denizens of the seas of the Silurian age. Our horseshoe crab, then, is the sole living representative of one of the oldest races of animals known.

Here on the sand, or in the muddy estuaries and river-mouths, occur many lesser species, more or less similar to the common "blue" edible crab, whose catciring is one of the amusements of the season. Most numerous, perhaps, are the fiddlers, running actively about, or peering from the deep, tubular holes which they laboriously excavate and which form their homes. They are vegetarians, feeding on the algæ, while the edible crabs, lobsters, etc., are carrion-feeders. Larger holes are inhabited by the Ocypoda crabs, which is the terror of the "beach fleas," for which it lies in wait until one comes within leaping distance. Another predaceous sand crab is the "lady," which buries itself at low-water mark, watching for its prey or against enemies-many 
fishes being crab-eaters. Another burrower, numerous in the wet sand at low tide, is the porcelain-like hippa, about the size and color of a pigeon's egg, which, with its relatives the shrimps and isopods, constitute the principal food of a long list of carnivorous fishes ; and many lesser, or even minute crustaceans, may be dug out of tubes and holes between tide-marks, not to mention the various mud-crabs (Punopeus), spider-crabs, squills, and so on.

Though an extensive catalogue of mollusks has been recorded for our sandy southeastern coast, the stroller upon these beaches can pick up a comparatively small variety of shells, few of which are very attractive. The most common are familiar " hard" or "soft" clams, or quohog and maninose, as they are called locally. The quohog is a type of heavy shell that lives on the surface of the sand, ploughing its way along from place to place, and the little ribbed heart-shell is a small and pretty cousin that is common.

Like other bivalve mollusks they get their food by sucking it in with the sea-water, in minute floating particles, through one of a pair of pipes; the nutriment is abstracted in the stomach, the air is taken up by the curtain-like gills to revive the blood, and the useless water itself spurts out of a second or outlet pipe. In the quohog, the various hard, ribbed, more or less brightly colored, heart-shaped 
species, the odd, hairy, flat-backed arcshell, or "blood clam," and other surfacekeeping species, the pipes are short; but in the thin-shelled soft clam, and similar kinds, that live deeply sunken in the mud and sand of the bottom, the pipes may be stretched out to a length of several inches. By this provision these clams are able to lie safely buried between tide-marks, contentedly waiting the return of the water that shall bring them refreshment. As you walk over the oozy sand where they hide, you see their position by numerous pinpricks, out of which will spurt, just ahead of your footsteps, tiny jets of water, showing that they have felt the jar of your approach and are hastily withdrawing their flexible pipes to safer depths.

Of the several sorts of thin-shelled bivalves of this type living on, or rather in, our beaches, the most attractive one is the razor clam, whose long shells, shaped like a knife-handle, show a glossy green and banded surface that is often exceedingly beautiful.

Of a very similar nature are the two or three species of glossy, or sometimes prettily marked, pear-shaped " mussels," which live altogether out of the sand, attached to some fixed object, as a rock, a bridge-pile, or the stems of the eel-grass, by a silken cable or byssus of their own spinning. They are to be searched for in the inlets or about the edges of bays and lagoons, where the salt tide has free ac- 
cess; and their stout masses are often of great service in resisting the wearing away of the soil by the currents. All these bivalves, like the oysters, increase by pouring forth, in midsummer, an immense number of eggs that drift about in the water, the prey of multitudes of aquatic creatures, so that only one in a thousand, perhaps, ever is hatched, and few of these survive long enough to come to maturity.

The univalve mollusks-those whose shells are all in one piece and usually spiral-such as the sea snails, periwinkles, etc., on the contrary, lay few eggs, but place them where they are subject to far less dangers. You will be sure to find. this month, along the sands curious skeins of yellowish lozenge-like cases, looking something like a toy snake. These are the egg cases of the large pear-shaped winkles, or conchs, whose dead-white shells, bereft of their brown, hairy skin are thrown up from the deeper water in every storm. and may always be obtained alive on the oyster-beds, where they do vast damage. They can move about rapidly, walking upon a broad muscular surface pushed out from the shell, which is dragged along like a burden; and they feel their way by the help of two tentacles projecting forward. Just beneath them is a mouth which may be protruded and enlarged so as to envelop and crush an oyster or similar victim, whose juices are then sucked out. In the absence of such living prey these and 
similar mollusks live upon dead fish and

other carrion, and thus perform a valuable scavenger service in the sea.

One finds rolling in the surf several sorts of spiral shells, which the oystermen call borers, with good reason, for these, too, are carnivorous, and creep about in search of flesh, dead or alive. Coming to a bed of mussels or oysters, they settle upon one, and, protruding a ribbon-like "tongue" studded with flinty "teeth," like a file, they bore with it a round hole through the shell and suck out its substance, while the inmate is powerless to resist the attack. Among the worst of them is one which is white, almost as globular as an apple, and sometimes two inches in diameter, called the Natica. It creeps about almost buried in the sand, under shallow water, near shore, and is, therefore, easily rolled up when dead; it is a shell of which the hermit-crabs are especially fond. If you search carefully you are pretty sure to find its eggs, scattered through a glue-like mass covered with sand grains, that has much the shape of a "stand-up" collar, and is one of the curiosities of the beach.

One might go on a long time in description of even the comparatively few shells, crustaceans, worms (in great variety), and so forth, to be found upon our sandy coast, or in the salt marshes, where various limpets and other small species live, and where the mud-flats are often black with multitudes of small species, one of 
which, the Melampus, is a land shell rather than a sea snail.

A rocky coast, however, is far more interesting to the maritime naturalist, because a much greater variety of animals and plants are to be found there. Rocky, weedy bottoms and shores are met with in Long Island Sound, and about Narragransett and Buzzard's bays, and prevail north of Boston, where Cape Ann and the coast of Maine are grand hunting-grounds for the marine zoologist. The abundance of crustacean and molluscan life about such places attracts the fishes that feed upon them, so that nowhere are tautog, striped bass, black bass, cunners, etc., more numerous than in the neighborhood of weed-grown reefs.

South of Cape Cod rocky reefs and shores are covered between tide-marks with rock-weeds (Fucus), "which hang in great olive-brown clusters from the sides of the rocks or lie flat upon their surfaces when left by the tide, but are floated up by means of abundant air-vessels when the tide rises." Mingled with these are several other algæ, among which the green "sea-cabbage" (Ulva) is one of the most abundant. Below this zone of Fucus there is a narrow zone, which is only exposed during spring-tides; in this the Ulva and many other more delicate green and red algæ flourish. These subaqueous forests and the pools left among the rocks by the daily retreat of the waters are pop- 
ulous with curious and beautiful forms of animal and vegetable life, now at the height of their energy and attractiveness.

"The animals of rocky shores," we are instructed by that veteran in this study, Prof. A. E. Verrill, of Yale, "are to be sought for in a variety of ways. A few occur quite exposed, clinging to the rocks or weeds, in defiance of the surf. These are chiefly univalve shells, barnacles, and such animals as grow like plants, firmly attached to solid objects - among these are the bryozoa, hydroids, and sponges. A much larger number seek shelter under the rocks, or on their lower sides, or in crevices and cavities between them; these must be sought by turning over the rocks and exploring the cavities concealed by the Fucus, etc. Many other species conceal themselves still more effectually by burrowing in the mud, gravel, and sand, beneath and between the rocks, but must also be sought for by digging with a spade, stout trowel, or some other tool, in the dirt exposed when the rocks are removed. The number of curious species of annelids, holothurians, bivalve shells, actiniæ, etc., which can be unearthed in this way is always very surprising to the inexperienced in this kind of collecting.

"Still other kinds can be found by carefully examining the pools and discovering the smaller animals by their motions, or by the shadows that they cast when the sun shines, or by noticing their burrows, 
or, if time will not admit of a more careful examination, by sweeping a fine handnet through the weeds along the edges. Many small crustacea, shells, etc., may also be found clinging to the corallines and other algæ growing in such pools, or even among the algæ lying upon the rocks, and especially among masses of detached algæ thrown up by the waves." 


\title{
CALENDAR FOR AUGUST
}

\author{
MAMMALS \\ (See July and September)
}

\section{BIRDS}

Sora Rails.-Begin to depart South.

Phalarofes.-Begin to pass South.

Dowitchers. - Pass South.

Sandpipers and other Bay-birds. - Become common.

Olive-sided Flycatcher.-Arrives from North third week.

Yellow-billed Flycatcher. - Arrives from North second week.

Acadian Flycatcher. - Departs South third week.

Chebec.-Departs South last week.

Tree Szuallows.- Roosting in marshes in vast Hocks; begin to depart South.

Rough-winged Sivillows. - Depart South third week.

orm-eating Warblers. - Depart South fourth week.

Nashville and Magnolia Warblers.-Arrive from North third week.

Bay-breasted and Blackburnian Warblers.Arrive from North second week.

Water Thrushes.-Passing South.

Wilson's Blackcap and Canadiun Warbler:Arrive from North third week.

Red-breasted Nuthatch-Arrives from North second week.

\section{BATRACHIANS AND REPTILES}

Serpents. - Shedding their skins. 
Ovoviviparous, Colubrine Snakes. - Bring forth young late in the month.

Green Grass-snake._Laying eggs.

\section{FISHES AND MARINE LIFE}

Sea fishes of all kinds abundant inshore.

Young of fresh-water fishes, and of many saltwater species, numerous, in shoals.

Larvæ and young of marine invertebrates crowd the water and are preyed upon by fishes and other enemies.

Jillyfishes.-Producing young (except $A u$ relia and Cyanea).

Annelids.-Spawning (except Nereids).

Larvæ of many crabs appear, especially of the hermits, soldier crabs, Hippa, Ocypoda, etc.

Slifper Limpet.-Frequenting the eel-grass, "where, in August, it often deposits its bright yellow eggs enclosed in small gelatinous messes, which are grouped in clusters."

\section{INSECTS}

Hornets, Wasps, and Yellow-Jackets.-Colonies very active; enlarging nests; rearing young; foraging for nectar, honey-dew, and insects; visiting golden-rod and other blossoms.

Bumble-bees. - Workersvery abundant; caring for young; storing honey and pollen in the cells of the brood comb. Some drones or males appear.

Mud-zuasps and Digger. Wasps. - Very active on bright, hot days, preparing and filling cells in which young are to develop.

Ichneumon-flies.-Continue very active in search of victims, as well as in feeding on the nectar of shallow blossoms.

Ladybird Beetles. - Abundant on herbs. shrubs, and trees. 
Click Beetles. - Adults still to be found.

Buprestid Bectles.-Adults flying in warm

sunshine; ovipositing in bark of trees.

Long-horned Beelle's.-Adults of some species abundant in golden-rod, cultivated asters, and other composite flowers.

Syrphid Flies. - Adults aluundant on blossoms of golden-rod and other tlowers; larva among colonies of plant-lice, feeding on the latter.

Monarch Butterfly. - Adults of new brood appear.

Regal Fritillary, or Iulalia Butterfly. - Aduits still abundant, many of them fresh from the chrysalis; visiting golden-rod, Vernonia, and many sorts of blossoms, and ovipositing upon violet leaves.

Silver-spot Fritillary, or Aphrodite Butterfly. -Adults continue on the wing, many of them fresh from the chrysalis.

Baltimore, or Phaton Butterfy. - Larva feeding on Chelone in swamps, growing very slowly ; towards end of month cease feeding and go into hibernation in the larval nest.

Violet-tip Butterfly. - Caterpillars of the second brood developing on hop and elm.

Gray Comma, or Progne Butterfly. - Larvæ develop on currant and gooseberry and change to chrysalids.

Hop Mirchant, or Comma Butterfly.-Adults of new brood still on the wing, laying eggs, and larvæ eating leaves of elm and hop.

Red Admiral Butterfly.-Larvæ of second brood feeding in folded nettle leaves.

Painted Lady Butterfly.-Larva on thistle and other composite plants.

Painted Beauty Butterfly.-Adults of new brood appear and lay eggs on everlasting. 


\section{August 3I}

Blue-eved Grayling, or Alope Butterfly.Adults continue on the wing, and during latter part of month lay eggs on grasses.

Viceroy" Butterfy.-Adults of second brood continue on wing and deposit eggs on leaves of willow and poplar.

Spring Azure Butterfly.-Adults of the second brood still to be found.

Tiger Swallowtail.-Butterflies deposit eggs on various trees, and larvæ feed upon foliage.

Clouded Sulphur Butterfly. - Adults still common everywhere.

Black Szuallowtail, or Asterias Butterfy.Larve mature and change to chrysalids; butterflies of second brood appear and lay eggs.

Cecropia and other large Moths. - Larva complete growth on their various food-plants.

Sphinx Moths.-Larve of many species to be found on many food-plants.

Harrest-flies, or Cicadas.-Adults continue singing; oriposit in twigs of trees.

Leaf-hoppers. - Adults of many species alıundant on leaves of trees, shrubs, and herbs; many on grasses.

Twirs-hoffers. - Adults common on branches of many herbs.

Locusts, or Grasshoppers.-Adults of many species in fields and meadows; ovipositing, especially during the latter part of the month.

Tree Crickets.-Adults common on leaves and branches; singing in the evening.

Black Crickets. - Abundant in fields and about logs, etc.; begin laying eggs in the ground.

Katydids. - Several species abundant, feeding on leaves of various plants, singing, and laying eggs.

Dragon-fies and Damsel-fies.-Very com. mon in the neighborhood of ponds and streams. 


\section{SEPTEMBER}

"The sultry summer past, September comes Soft twilight of the slow declining year." 



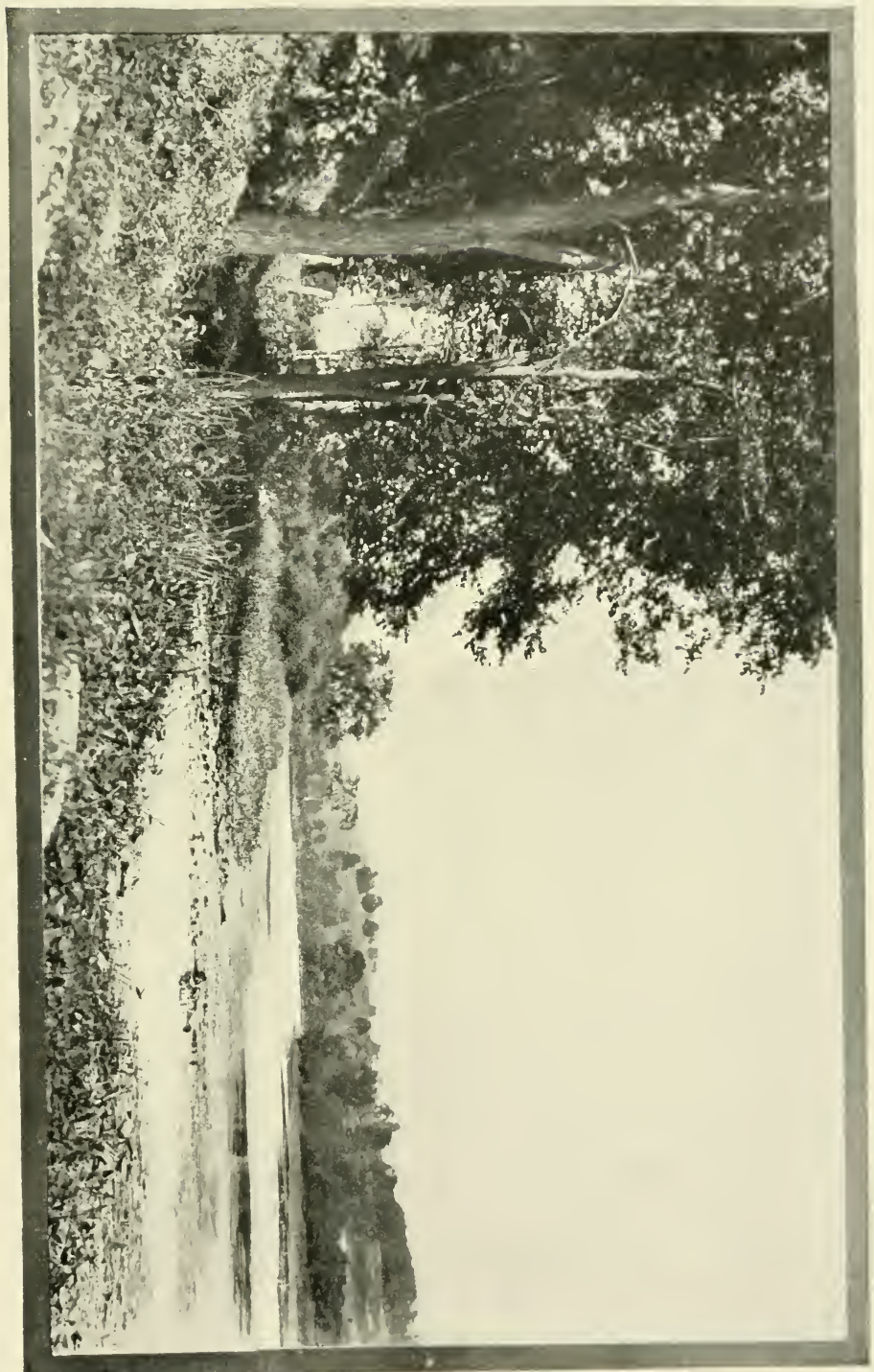




\section{SEPTEMBER}

SEPTEMBER, the seventh month (Latin September I septimus, seventh) of the old Roman calendar, is counted as the first of the autumnal quarter in our arrangement, but practically summer lasts through to Michaelmas. September is the month of fruits. "Grapes," says Wilson Flagg, "in purple clusters, basking in the sunshine, garland the stone wall, which seems like a natural trellis. Apples are reddening on the orchard trees, under the ripening influence of the sun, or lie in heaps of variegated colors upon the ground. Peaches with downy cheeks, wearing the blush of mellow ripeness, are drooping voluptuously from their slender boughs. Quincetrees, in gleaming rows along the fences, tempt the visitor with the golden apples of the Hesperides. Every way-side in the country is adorned with a similar profusion, and glittering varieties of fruits hang from thousands of boughs and sprinkle the green turf of every orchard."

The mammals, large or small, are not as much in evidence yet as they will be later, but certain ones are common enough. The young of most have now grown to two-thirds their full size-per- 
September 2 haps more, and small, inexperienced woodchucks begin to be frequently seen among the second-growth clover, and are troublesome to the rural gardener and celery planter.

"In September the woodchuck sits by his hole," says Schuyler Mathews, "the perfect image of listlessness; he is as absolutely motionless as 'a bump on a log.' Possibly he meditates upon the changing aspect of nature; at any rate, he does not move a muscle, and it is doubtful whether his mind works. Approach him never so silently and cautiously, and he pops in without a preliminary movement. On one occasion, though, I did actually see him change his position before he disappeared. At first sight he was upright; then, on my nearer approach, he dropped horizontally, and when I got within ten feet of him he was gone. Presently I took a harmonicon from my pocket and softly played upon it; being highly susceptible to the sweet influence of music, he reappeared at his doorstep, and, with a slight expression of disturbance on his usually dull countenance, eyed me with some curiosity and disapproval. I imagined if he possessed the power of speech he would have said, 'This may be quite a clever performance, sir, but, on the whole, I'd thank you not to disturb my autumn reverie.'

Before the end of the month, however, nearly all have disappeared, having gone 
thus early to the holes they have bucn digging, or to the crannies they have been making warm with a thick bedding of dry grass, where they will sleep out the larger part of the cold season to follow.

Now, too, as the corn develops into the soft, milky stage, when it is at its sweetest, the 'coons, old and young, come to feed on the juicy kernels-stealing from the woods by moonlight, watching for dogs and men, dodging among the shadows, racing across the lights, and eagerly stripping the husks from the coveted ears. These handsome animals are undergoing their semi-annual molt, and the hair coming off in patches, to be replaced presently by the darker, closer winter coat, gives them a very ragged appearance.

The milky cornstalks are climbed by the squirrels, too; but they come by daylight. On Western frontier farms it used to be needful to watch the fields and drive the gray squirrels away, if enough of the crop was to be saved to repay the planter. This task fell to the boys. Squirrel families are divided at this season, the mothers and young keeping house together in their summer homes of leaves, and the fathers and elder brothers ranging the country by themselves; all feed largely upon various mushrooms.

This separation of the sexes in late summer is characteristic of all, or nearly all, the wild quadrupeds. The deer of various sorts are good examples of it, the 
mothers and fawns and yearlings straying togrether, wherever they can get most relief from the flies, while the bucks are still hiding in secret nooks, waiting for their antlers to put on their final points and harden.

In summer the deer come out of the thick woods and resort to the borders of streams and ponds, where at night they love to wade into the water and feed on the lilies and other succulent weeds and grasses; and they are often seen swimming even large lakes as a short cut to other pastures, where they browse until daybreak warns them to seek the seclusion of the thickets. As September advances, and the marsh plants begin to wither and fall down, the deer forsake the watercourses for the forests, where a plentiful supply of food now exists-best of all beech-mast, of which they are very fond, and upon which they fatten amazingly. By this time, too, the new antlers of the buck, which he has spent the summer months in nursing, are free from the "velvet," and, feeling himself able to battle with all competitors, he sets about his wooing. Coincidently both sexes are shedding their reddish summer coats and taking on the warmer "blue" pelage of winter; and the spots of the fawns disappear. The deer of the Rocky Mountain region are three or four weeks earlier in these changes.

Other mammals are now changing their 
coats and putting on winter wear, and all the pelts of the fur-bearers are ragged, uncertain in color, and comparatively worthless to the trapper, who pays little attention to them until later. The birds are molting also, exchanging their bright tints for the duller hues of the travelling and winter dress; and the nuptial glow that distinguishes many fishes in the early part of the summer has faded. Serpents, however, are gayer in color than usual, having recently sloughed off last year's scaly coat.

September is the fattening time for the four-footed folk. Insects are plentiful, and seeds of the flowering herbs and of many wild grains have ripened, so that before the end of the month mice, squirrels, chipmunks, gophers, and the rest are at work filling their granaries; the muskrats are planning their houses, and where any beavers are left to us they are busily cutting the first of their winter store and repairing or extending their dams and lodges. Even the bear is practically doing the same, for the berries and nuts upon which he gorges himself in the hill thickets at this time are turned into the thick layers of fat beneath his loose hide that shall nourish him during the long period of sleepy famine ahead.

But the most interesting feature of the month in the animal world is the southward migration of the birds, now at its height. 
The northward movement of the birds in spring was discussed in the chapter on May. Now, they having accomplished the domestic duty which led them north, we see or hear them, during all these September weeks, hurrying back again to their winter homes in the sunny South. Even before August comes to an end a large part of the resident songsters of the more northerly States have departed, and the September woods would be lifeless, indeed, were it not for the new arrivals from the North.

Now snipe, sandpipers, and plovers gather in chattering bands and dart away in the dusk to feeding-grounds not threatened by frost; the woodland birds flit cautiously from copse to copse, scudding to shelter as they see following overhead the ominous forms of hawk and owl, or watchful for the weasel and his kin, who fatten upon the moving crowds; ducks and greese cleave their way through the morning air to feeding-places where unwilted food still awaits them, and the marshes are clouded with vast flocks of blackbirds, swatlows, and the like, congregating to fly southward in company.

This gathering into great bands by many birds is one of the features in which the autumnal differs from the vernal movement, and nothing is more curious than the behavior of a flock or groups of flocks of redwings, neatly uniformed and soldierly, wheeling and advancing in long 
platoons, or settling as if by order on the reeds. Quite as multitudinous, but not so picturesque, are the gatherings of whitebellied sivallows in the marshes.

Again, as in spring, it is noticeable that the old males lead the host of each species. Restlessness to depart seems to influence them as soon as they have seen that the family eggs are hatched and the young likely to be reared. Then, free of care, they begin to long for the South, and being strong of wing they keep ahead of the females and weak youngsters, which latter start as soon as they are able to undertake the journey.

There is no mystery, then, about the young finding their way-they follow their elders, who have been taught the route and remember it, aided, no doubt, by a keener faculty for finding their way - a more perfect "sense of direction"-than civilized humanity possesses, but perhaps not more perfect than belongs to certain savages. They follow certain great routes or highways, as has been described in speaking of the northward flight in June; and it is probable that their main object in flying at so great a height as they often do, is in order to get a wide survey of the landscape, and so keep their landmarks in view, making their way easily from point to point invisible at a lower level.

Persons looking at the face of the full moon with a telescope on September evenings, may see hundreds of birds pass- 
ing across its bright disk, at heights a quarter or half a mile above the earth, for now, as in the spring, the migratory journeys are made mostly in the dark hours, the daylight being given to resting, feeding, and some leisurely progress. That the necessity for feeding by day is the main reason why they fly at night is shown by the fact that such birds as swallows, swifts, nighthawks, and certain others that obtain their food on the wing, do not do this, but proceed wholly by daylight, foraging as they fly.

In clear nights, and especially when the moon shines, the woodland birds collect at sunset in little bands and rise straight up to a considerable height, then bear away on their course. But when the nights are dark and misty, as so often happens in early autumn, yet not so stormy as to stop them, the birds skim low over the tree-tops and houses, freling their way along and often getting confused and scattered. On such nights no one who is out in a quiet, open place, where the chatter of the katydids and other noises do not fill his ears, can fail to hear in the gloom above him the almost incessant voices of passing birds, calling to one another in the effort to keep together as they grope their way along. It is one of the pleasures of the autumn to listen to these anxious-hearted, invisible travellers, most of whom will be recognized by the trained ear. 
So they drift by us through the bright autumnal weather, leisurely by day, hurriedly at night, wave after wave, following the turning of the leaves till they come to the still verdant vegetation of tropical lands, and can settle down to six months of pleasure and plenty.

September is the birth-month of many of the North American snakes, especially of the venomous species. The crotaline snakes mate in March in the Gulf States -later, of course, in the North, but immediately after they come out from their winter-quarters. This is true of all the rattlesnakes, moccasins, and copperheads, and also of several other non-venomous serpents. In September their young are born from egg - like envelopes retained within the mother's body until the embryos have been perfected and are sufficiently active to tear their way out of the case, almost as soon as they are voided into the world, when they begin at once to look out for themselves. The ordinary number produced at a birth by the rattlesnakes and their kin is six or seven, each about seven inches long.

Other snakes that are ovoviviparous and bring forth their young in late August or September (according to latitude and seasonal temperature) are the various garter, striped, or ribbon snakes (Eutcmia and Storeria), and the water-snakes (Tropidonotus). All these produce from five to seven young only-very few, as compared 
with the young born from the egg-laying snakes, which are exposed to many dangers in the eggs from which the young of the viviparous snakes are saved.

Several snakes do not lay their eggs until late in August, or even until this month, most of them hatching by the middle of September. This is probably true of the blacksnake, although exact evidence of it is wanting. It is known to be true of the pretty green snake (Coluber vernalis): "On August 3oth," says F. IV. Putnam (Am. Nat. ii., I34), "I found the eggs . . . seven in number, just under the old bark and moss of a decayed stump in a meadow. These eggs, which were just on the point of hatching ... were an inch in length by half an inch in diameter, and the young snakes were 5.13 inches long."

As to the hoynose (Heterodon), its eggs have been reported in May, July, August (3oth), and September; and Mr. O. P. Hay (Proc. Nat. Museum, I 892), remarks : “I think that this species, like most other species, produce their young rather late in the season; but I see no reason for not believing that some individuals may not bear their eggs over the winter and lay them in the spring."

The toads go into hibernation this month - earliest of their race. Young salamanders complete their metamorphoses, and the green newts lose their gills and go ashore, where their "color gradually changes from an olive-green to 
brownish-red, and finally, during the same season, assumes a bright yellowish-red."

Among the fishes the sand-flounder and calico - bass, or cloverlip, become prevalent, and the spot, or Lafayette, appears. Sword-fish leave the coast, and sheep's-heads disappear southward from the bays. Young black-bass return inshore from deep water, and the sea-horses produce their young among the eel-grass in northern bays. In the southerly mountains brook-trout are spawning, but in New England and the more northerly districts October is the breeding-month for this charming species. In September they are at their best in the northern lakes.

Among mollusks, the most notable event of the month is the shoreward approach of the scallops, and the beginning of their catching for market; but certain other mollusks and marine invertebrates discharge their eggs in the autumn.

Insect life is still rampant in all its forms, but the entomologist sees seasonal peculiarities. He notes the reappearance, as a second brood, of many butterflies and moths that he has not seen since early summer. Certain late larvæ are busy and destructive. Those of a great haw $k$ moth are feeding on the pine-needles; the silk-worms begin before the month is out to form their cocoons, and such pests as the army-worm appear this month, when they come at all; while everybody takes note that the grass is full of crick- 
ets, and that the trees are populous with locusts, whose stridulation keeps us awake half the night to listen to their incessant disputation over whatever it was that katy did or didn't.

Mole crickets make a great part of this noise, filling the air at night "with an unceasing dissyllabic thrill from early August till after frost."

Ants become prominent now also, swarming, as a rule, early this month. Our most common ant is the ty pical little red one (Formicu sanguinea), which also exists in Europe and Africa. In this country it throws up hillocks often a yard in diameter and eighteen inches high, having many holes, which are entrances to the formicary or home of the ant-community beneath the hillock, where there is a labyrinth of galleries and whence other galleries and tunnels radiate in all directions. In such a formicary the workers (and sometimes the winged ants, also) hibernate, but all arouse themselves early in the spring to take care of the eggs and larvæ, which have been produced the previous autumn. Some species swarm on some calm, sultry day in the course of the summer, but the common little yellow ant of our door-yard, whose rings of excavated sand-grains decorate the spaces between the stones of the garden-walk. the big black ant that dwells in decaying stumps and logs, and some others, wait to swarm until this month. Thus the sunset 
air of any of these warm September days may be filled with shimmering hosts of the winged forms in pursuit of the escaping queens. This marriage flight over, the females enter their formicaries and lay the eggs which shall produce, next spring, new colonies or replenish the old; and all the winged ants, having no further use for their wings, pluck them off and settle down to work in preparation for the winter.

It is not yet too late to study the habits of many nest-storing wasps, which continue their sunmer work of provisioning the cells in which their young are to hatch far into the autumn. Read the admirable and entertaining writings of Mr. George W. and Mrs. Elizabeth G. Peckham as to these habits, and learn how to observe them. Common among the late summer wasps are those of the genus Pelopaus, which build nests of plain mud in slieltered places, and store them with various sorts of spiders. These are stung for the purpose of overcoming resistance, rather than, as popularly believed, for the purpose of paralyzing the victims for the purpose of keeping them alive. You will find upon examination of cells recently provisioned that while most of the spiders are dead, many of them are alive; these living spiders die from day to day, the death-rate depending upon the amount of poison that has been injected into their bodies. 


\title{
CALENDAR FOR SEPTEMBER
}

\author{
MAMMALS
}

Woodchucks.-Begin to retire to sleep.

Squirrels and Raccoons. - Attacking the maize : eating toadstools as dainties.

MTuskrats. - Beginning winter lodges.

Deer--Resorting to the edges of pouds, the bucks freeing their borns from the "velvet."

\section{BIRDS}

Herring Gull.-Arrives from the North.

Black on Dusky Duck.-Arrives.

Teal Ducks. - Pass South last week.

Pintail or Sprigtail Ducks. - Pass South last fortnight.

Broadbill, Bluebilled, or Scaup Ducks.Pass South.

Bittirns.-Depart South third week.

Great Blue Heron.-Passes South.

Sora Rails and Coots.-Pass Southward.

Phalaropes. - Pass Southward.

Sindpipers and other bay-birds.-Common.

Migratory Hawks. - Arrive from the North and gather into flocks.

Sapsucker.-Passes South last fortnight.

Kingbirt.-Departs South third week.

Crested Kinglird and Olive-sided Flycatcher.

- Depart South first fortnight.

Kusty Blackbird.--Arrives from North second week.

White-throated Sparron. - Arrives from North third week.

Snowubird. - Arrives from North third week. 
Rose-breasled Grosbeak.-Departs South third week.

Purple Martin and Eave Swallow.-Depart South second week.

Bam Swallow.-Departs South third week

T'ree Sivallow's. -Slowly moving Southward.

Bank Si'allow'-Departs South last week.

Warbling and Yillow. throated Vireos. Depart South first week.

Blue-winged Warbler.-Departs South second week.

Nashoille Warbler. - Departs South last week.

Parula IVarbler.-Arrives from North last week, and slowly passes South.

Summer Warbler.-Departs South last week.

Black-throated Blue, Magnolia, Blackpoll, Blackburnian, Black-throated Green, and Yel. low Redpoll Warblers.-Pass Southward all the month.

Chestmut-sided W'arblin. - Departs South fourth week.

Prairie Warbler. - Departs South second week.

Water Thrushes.-Pass Suuth all the month. Chat, Hooded, IVilson's Black-capped, and C'anadian Warblers. - Depart South first week.

Titlark.-Arrives from North third week.

Winter Wren and Brown Crecpir.-Arrive from North third weel.

Veery.-Departs South first week.

Gray-cheeked and Olive-backed Thrushes. Pass South last fortnight.

\section{BATRACHIANS AND REPTILES}

Newts. - Complete transformations and leave the water. 
Toads.-Go into hibernation.

Rattlesnakes. - Bring forth six or seven young.

Copperheads.-Produce five to seven young.

Garter or Ribbon Snakes.-Produce young.

Water-snakes. - Produce young.

Hognose and Green Grass Snakes. - Lay eggs and the eggs hatch.

\section{FISHES}

Sand Flounders.-Becomes common.

Calico-bass.-Becomes prevalent.

Spot, or Lafayette. - Approaches the shore.

Sivordfish.-Disappears.

Sheepshead.-Leaves the coast.

Sea-horses. - Spawn among the eel-grass.

Trout. - In finest condition for fishing in northerly waters; spawn in southerly waters.

\section{INSECTS}

Hornets, Wasps, and Yellow-jackets.-Queens mature in the nests.

Bumble-bees. - Queens mature in the nests.

Mrud-wasps and Digrer-wasps. - Larve become full grown: many spin cocoons.

Ichneumon - fies.-Many adults still found; earlier stages developing in connection with various hosts.

Ladybird Beetles. - Adults abundant.

Black-blister Beetles. - Adults abundant on golden-rod.

Syrphid-flies. - Larvæ, pupæ, and adults found much as in August.

Drone-fies.-Adults develop in numbers from "rat-tailed" larvæ in ponds.

Monarch Butterfly. - Adults migrate South. ward. 
Regal Fritillary or Idalia Buttirfly.-Some adults still present and even laying eggs. Eggs hatch about a month from time of laying, and larva immediately find shelter for winter.

Violet-tip Bulterfy.-Adults of second brood appear, going into hibernating quarters late in autumn.

Compton Tortoise Butterfy' ( J-album). - Butterflies flying about borders of woods, in orchards, and along highways.

Gray Comma, or Progne Butterfty:-Butterflies of second brood emerge from chrysalids, and on bright days fly about.

Hop Merchant, or Comma Butterf $y^{\prime}$. - Adults of second brood appear and soon go into hibernating quarters.

Red Admiral Butterfly.-Adults of second brood appear and generally continue on the wing through October, visiting dahlia and other blossoms, and sipping juices of decaying fruits.

Painted Beauty Butterfy'. - Full - grow'n caterpillars and chrysalids to be found on or about everlasting during first half of September ; butterflies appear during last half and remain until end of October.

Painted Lady'Butterfy. - Adults of second brood appear and remain until colder weathes sends them to hibernating quarters.

Red-spotted Purple Butterfy'. - Aduits of second brood on the wing, and depositing eggs for the caterpillars that are to hibernate.

Vicercy Butterfly._Larræ construct winter cases on twigs of willow and poplar, and go into winter-quarters.

Tiger Sivallowtail. - Larva mature and change to chrysalids. which remain as such until the following spring. 


\section{September 30}

Imported Cabbare Butterfly. - Larve seek shelter and change to chrysalids, to remain in that condition until the following spring.

Clouded Sulphur Butterfly. - Adults common, more or less worn, especially in latter part of autumn.

Green Clouded Suiallouitail.-Larvæ of second brood mature and change to chrysalids, remaining in this condition through the winter.

Black Siéllowtail, or Asterias Butterfly.Larvæ mature and change to chrysalids, in which condition the insect passes the winter.

Cecropia and other Large Moths.-Larvæ spin cocoons upon or beneath the food-plant. Change to pupæ within the cocoons.

Sphinx.Moths. - Larvæ of manyspeciesgointo the ground, where they pupate in earthen cells.

Leaf-hoppers and Twig-hoppers.-Adults still common.

Aphides, or Plant-lice.-Sexed generations appear ; winter eggs deposited about buds and on leaves of perennial herbs, ovipositing being continued through October.

Locusts, or Grasshoppers.-Adults continue to lay eggs during first part of month ; many die before end of month, though many are still to be found in October.

Tree Crickets. - Adults lay rows of eggs in canes of raspleerries and blackberries, and in twigs of trees and slirubs.

Black Crickets. - Abundant, females depositing eggrs in the ground ; many live on until the advent of cold weather.

Katydids.-Adults still present, laying eggs. Dragon-fies and Damsel-fies.-Still found though less abundant towards the end of the month. 


\section{OCTOBER}

"Some forest rill, With leaves and water rust o'erspread That seemed an amber light to shed On all was shadowed there." 
$a$ 


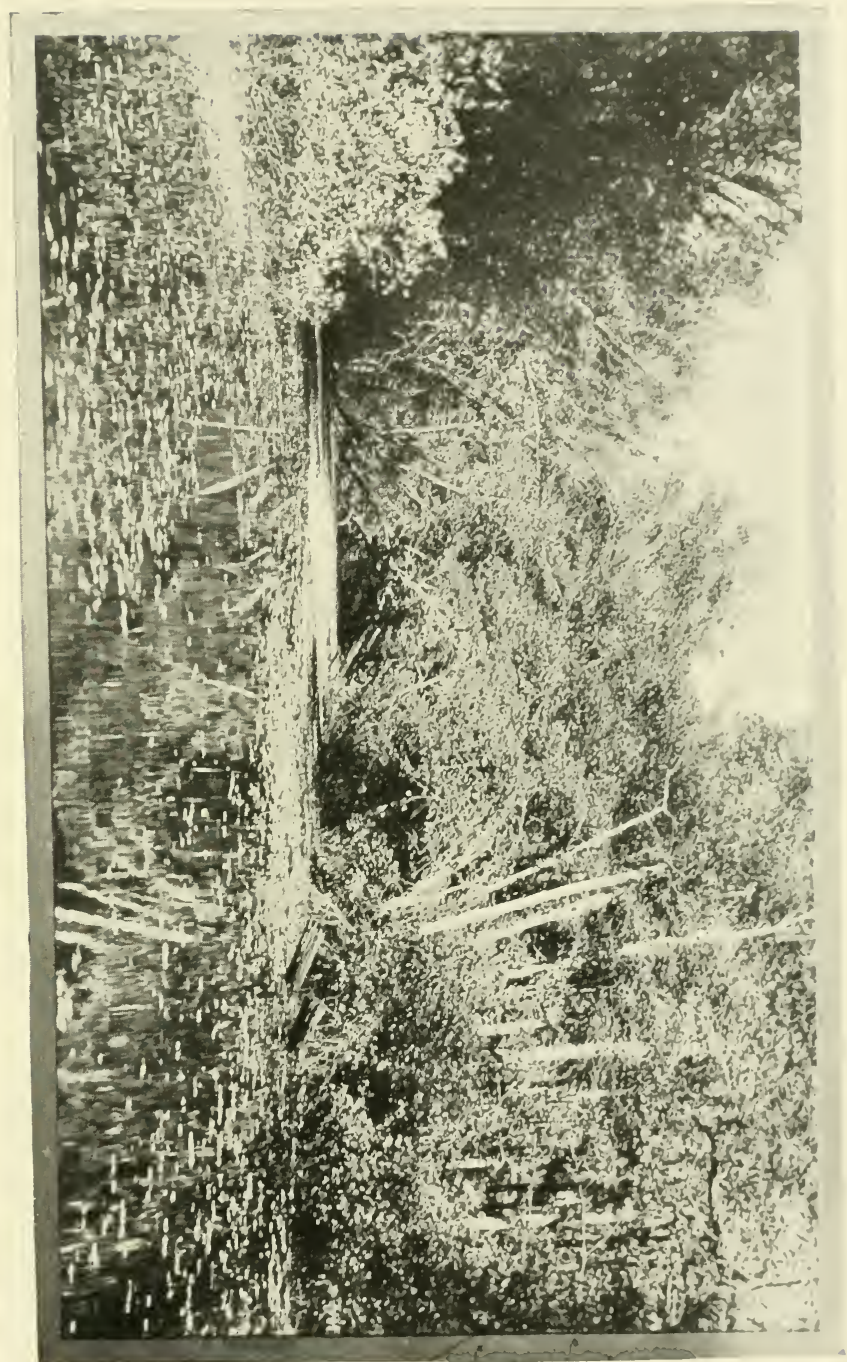




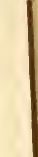




\section{OCTOBER}

PROBABLY most of my readers would vote for October if they were asked to choose the finest month of the American circle of the year. The direct and blazing rays of the summer sun now slant only warmly upon the earth, and the cool nights bring refreshing slumber and put an end to insect annoyances. This median temperature promotes steadiness of weather, when lovely golden days and clear nights are likely to follow one another in pleasant regularity; and yet no one is disturbed by the drouth, for no longer are growing fields or gardens in need of quickening showers, and all are confident that November will replenish the springs preparatory to winter.

Now, by a curious analogy, with the daily glories of sunrise repeated at evening in the sunset glow, the woods and fields that have been green or sere through midsummer put on colors as rich and varied as were worn in the gayest weeks of spring: only now it is not a multitude of brilliant flowers that enrich the landscape, but a greater and more extensive display of gaudy leaves. "The increasing scarlet and yellow tints around 
October 2 the meadows and river remind me of the opening of a vast flower-bud. They are the petals of its corolla, which are of the width of the valleys. It is the flower of autumn, whose expanding bud just begins to blush.'

The universal greenness of plants is due to the presence of a complex pigment called chlorophyll, the varying abundance and mixtures of which give the diversified greens of foliage. It is most abundant and important to the plant when it is growing and putting forth its leaves vigorously in the spring; and, after the plant has accomplished its duty of flowering, the leaves grow duller in color because the chlorophyll has begun to be absorbed. This goes on until finally, when autumn comes, all or most of the chlorophyll has disappeared from the foliage and herbaceous stems, and has been transformed into something else in the plant. Along with it, however, other color-making materials form a part of the cell sap. One of these is tannin, present in all plants, especially in woody ones, and giving rise under the influence of growth and chemical influences to a class of pigments called anthocyans, which furnish a range of purple, red, and brown tints. When the green chlorophyll disappears these other colors show themselves in the foliage, and their varying intensity, mingling and changing under the chemistry of sunshine, air, rain, and frost, furnish the 
hues of autumn, and do it out of the

same materials that, acted upon in a different way, and under other circumstances, make the flower tints of spring. The petals of the rose, the brown leaves of its bush, and its scarlet seed case, or " hip," which remains to glow against the snow and feed the birds, are all painted from the same palette, but by different brushes.

Another material assisting in producing bright colors is the fatty particles in the plant juices, which, when the chloropliyll retreats, appear upon or near the surface, and give a yellow or reddish tinge to the stems and leaves, and sometimes to the bark and seeds.

"How interesting now," exclaims the Sage of Walden, "by wall-sides and on open springy hill-sides, the large straggling tufts of the Dicksonia fern above the leaf-strewn green sward-the cold fallgreen sward!... Long, handsome, lanceolate green fronds pointing in every direction, recurved and full of fruit, intermixed with yellowish and sere brown and shrivelled ones, the whole clump perchance strewn with fallen and withered maple leaves, and over-topped by now withered and unnoticed Osmundias."

Now is the time to go nutting; and what in the country boy's experience equals that, from January to December? But no matter how early the happy urchin seeks the hickory he has been watching, or the butternut or walnut left grow- 


\section{October 6}

ing by the pasture fence, or the grove of chestnuts on the hill-side, he finds that other nutters are ahead of him. Chipmunks race along the fences by the lane, their cheeks full of beechnuts and acorns, and disappear down some hole to deposit their store and creep out when they know by his whistling that the lad has gone past and the way is clear. They are earliest of the squirrels to prepare their provender, making hundreds of journeys, with cheeks stuffed with all sorts of good things; for before the end of the month (at least in the colder regions) they will no longer care to brave the chilly air, unless it be for an hour or two at noon, but will want to curl up in their warm little caves and begin to subsist on their larder.

As the boy climbs the fence and turns into the woods, pausing a moment to whistle back to Bob White, who calls from the stubble - field where bands of sparrows are drifting about like blown leaves, he hears a rustling in the underbrush, and sees a gray squirrel sitting up under a big oak, clutching an acorn in the little paws that are held so prettily to his breast and waiting breathlessly to learn if there is any danger.

The boy sits still upon the top rail and watches the animal. Satisfied that he has nothing to fear, the gray drops down on all fours and begins scratching among the leaves, the white border of his plumelike tail rippling in the clear light, and ris- 
ing higher and higher as the leaves fly backward and the head disappears from sight. Presently the squirrel reappears, and, turning about, scratches the leaves and soil back again, pats them down with his feet, then runs away and up a tree, cack ling like a proud young chanticleer. The boy goes over to see what has been done, but finds it a little difficult to discover the place where the squirrel had been digging. When he succeeds, he paws away the loose soil until he finds, perhaps three inches deep, a single big acorn, the one the little creature had been carrying. Did he care to, and know enough, he might find perhaps fifty others buried here and there in the neighborhood, for it is thus, one by one, that the gray squirrel hides his winter supply of food. It is a very simple method, and a safe one; but how does the creature (who does not hibernate at all, even in the coldest weather) ever recover these nuts and acorns when he wants them? Memory, undoubtedly, helps him a great deal; but he is guided mainly, it seems, by the sense of smell. At any rate, a good many of them are found, even when covered with two or three feet of snow, or needing to be dug out of ground frozen into hard ice; on the other hand, many are never exhumed, but simply rot, or, when circumstances favor, sprout into saplings. The gray squirrel is perhaps the foremost American tree planter, and 
should be the special symbol of Arbor Day.

Much more anxiously busy at this season are the red squirrels, for either they feel their weakness to cope with the famine of the snowy months, or have a greater prudence. This ever active, ever jolly, ever mischievous little rascal does not hibernate, and thus do without food, but diligently prepares his home and his larder so that when bad weather comes he may be well provided for. In the Southern States, of course, little such precaution is necessary. There are few days when the weather will not permit him to go abroad, and few places where he cannot get something to eat without taking much trouble to save it up. In the North, however, where the winter weather is long and rigorous, he must be more provident, although able to be out most days, no matter how cold. Choosing some cranny in a hollow tree, or, better yet, an old woodpecker's hole, he fills it full of grass and leaves, thus making a nest in which, wrapped in the rug of his own furry tail, he can defy even Canadian frost.

"When the summer has grown old," says Merriam, speaking of the Adirondacks, "and the mellow days of early autumn cast a glow of color over the sumac and woodbine, the prudent squirrel has commenced to gather the provisions for his winter use. Impatient to make sure of his store, he does not wait for the 
nuts to ripen and fall, but cuts the stems by which they hang, till many lie scattered on the ground below. He then descends and collects them in a heap between, or near, the roots of the trees; or, if he thinks that too exposed, carries them directly to some hollow log or stump. Later in the season, when the mast is fully ripe, and the danger from mould is past, he fills the hollows of the limbs and trees about his nest, and often secretes reserve hoards in his burrows in the earth. In the evergreen forests he lays up supplies of cones. . . He cuts the yet green cones from the branches, and, when a sufficient number have fallen, takes them to some hiding-place to ripen for his winter's fare."

This is only a glimpse of the careful and skilful economy practised by many of the small rodents at this season of plenty.

The birds of the season are chiefly those which can subsist on seeds and fruit mainly, if not wholly. "The birds seem to delight in these first fine days of the fall," Thoreau observes; " in the warm hazy light-robins, bluebirds (in families on the almost bare elms), phœbes, and probably purple finches. I hear halfstrains from many of them, as the songsparrows, bluebirds, etc., and the sweet phe-be of the chickadee.

"I see and hear probably flocks of grackles with their split and shuffling note, but no redwings for a long time: chipbirds [tree-sparrows?] . . baywings 
on the walls and fences, and the yellowbrowed sparrow. . . Going over the large hill-side stubble-field west of Holden Wood, I start up a large flock of shore larks, hear their sveet, sreet, and sveet, sveet, sveet, and see their tails dark be. neath. They are very wary, and run in the stubble for the most part invisible."

For all these birds the weeds and grasses bear a sure and bountiful harvest. and bush and vine are filled with berries. Think what a host of sumachs await the coming of birds to feast upon their velvety masses of seeds; and what millions of acorns for the woodpeckers, and nuthatches, and jays! Along the old fences rise the thorny barberry bushes, scarlet with tart fruit and the rich offerings of choke-cherry and sweetbrier. The frosts open the chestnut burrs, and the nuts patter down, to the delight of jays and squirrels-and boys; and the berries of the red cedars are turning ripe and purple, while the blueberry bushes still hold much sweet though half-shrivelled fruit. Of the weeds, how many bear tiny pods and vessels full of seeds, ready to pop open at a touch and reveal their treasures, or to cling to whatever touches them and be carried away!

The heyday of the deer comes now. By the time October opens, the antlers of the deer have been perfected, and the bucks are now ranging the forest wooing the does and fighting all rivals; their 
necks are swollen, and their tempers so uncertain that now and then they will charge even a man, should they encounter him, not only stabbing with the antlers, but striking viciously with the fore-hoofs.

In the clear cool water of the northern ponds and streams, now, the salmonoid fishes are depositing their spawn-salmon, trout, winninish, and the rest. The trout begin to spawn about the second week of the month, and continue doing so all winter. "In midsummer," to quote a pleasant summary of trout-life once written by the late G. Brown Goode, "they lie in the bottoms of the lakes cooled by springs, in the channels of streams, or in deep pools, lurking behind rocks and among roots. In spring and early summer they feed industriously among the rapids. At the approach of cold weather in the autumn they hasten to the clear, shallow water near the heads of the streamlets. It is at this time that they deposit their eggs in little nests in the gravel, which the mother-fish has shaped with careful industry, fanning out the finer particles with their tails, and carrying the larger ones in their mouths. After the eggs are laid the parent fish covers them with gravel and proceeds to excavate another nest. The same nests are said to be revisited by the schools year after year."

"I hear out towards the middle [of WValden Pond], or a dozen rods from me," 
says Thoreau, under date of October $3 d$, "the plashing made apparently by shiners; for they look and shine like them, leaping in schools on the surface. Many lift themselves quite out for a foot or two, but most rise only part way out, twenty black points at once. There are several schools indulging in this sport from time to time as they swim slowly along. This I ascertain by paddling out to them, Perhaps they leap and dance in the water just as gnats dance in the air at present. I have seen them before in the fall."

The streams and swamps and shores of lake and ocean abound in half-grown creatures of every sort that live in and about the water. Whirligigs by the thousand dimple the water of ponds and swampy creeks, skaters dart hither and thither over the glassy surface, and above it hover those living gems, the dragonflies, rapidly thinning out, however, as the cold nights begin to pinch their gauzy wings. Along the seashore fishes and crustaceans, mollusks, and all creatures able to move, are retreating slowly to the warmer depths.

The cold-blooded reptiles feel the frosty nights and retire to their winter-quarters, now and then a snake or turtle being lured forth by some Indian summer warmith. Latest of them to retire, perhaps, is Pickering's hyla, whose sharp peep resounds through the autumn woods, until really bad weather arrives, long 
after the larger changeable tree-toad has been silenced.

As the October days grow shorter and the month draws to a close, insect life lessens. The cicadas cease their incessant chorus, though the loud calling of mole crickets is still heard, and gnats and flies still dance in the golden sunlight. The butterflies that last on into the fall, being outwardly of the dull-hued sorts, are inconspicuous among the falling and sombre foliage. One curiosity of butterfly life is often noticeable at this season along the southern coast in the habit of the milkweed butterfly (Ancsia plexippus) of swarming on the branches of trees in such masses as to reclothe them apparently with the leaves that have lately fallen. These hosts of butterflies are migrating.

Crichets are, perhaps, the most noticeable of the larger insects, leaping about our feet wherever we go along the dusty roads or in sandy places. They fall into hopeless captivity in little sand-pits, and tumble headlong into the water, where the pickerel lie in wait along the banks to snatch them down. It is amusing, also, to watch them "shinning" up a tall bare weed to get something on its summit. "Their still larger cousins, the mole-crickets, are creaking loudly and incessantly all along the shore. Others have eaten themselves cavernous apartments, sitting-room and pantry at once, in windfall apples." 
Aquatic insects are still lively, but one by one sink to the bottom, where the caddis-worms are snug in the cases that will protect them until spring. "I find caddis-cases with worms in Second Division Brook," Thoreau notes on October 2Ist; "and what mean those little piles of yellow sand on dark-colored stones at. the bottom of the swift-running water, kept together and in place by some kind of gluten, and looking as if sprinkled on the stones, one-eighteenth of an inch in diameter? These caddis-worms build a little case around themselves, and sometimes attach a few dead leaves to disguise it, and then fasten it lightly to some swaying grass stem or blade at the bottom in swift water, and these are their quarters till next spring. This reminds me that winter does not put his rude fingers in the bottom of the brooks."

In one direction the insect world manifests itself now very strongly, for this is the month when the gossamer of spiders is all too prevalent for our comfort.

Often in late summer the bushes are covered with threads that are attached by one end and blow out in the wind. These become especially numerous in autumn, and everybody knows that they are threads spun by spiders, but all do not know how or why. Small spiders, and especially the young of the Lycosa family (the running spiders), are very fond now of flying, apparently "just for fun." They 
will crawl to the top of a bush or fence, to some exposed point, place all their feet in a bunch, with the head held down and the hinder part of the body up, and then exude from the spinning apparatus at the tip of the abdomen a thread, or sometimes a brush-like cluster of threads, which is caught by the breeze and floats out as it lengthens, until finally it has buoyancy enough to carry the spider away aloft out of sight, or drift him off across the country until he strikes some foothold and stops. Then he may simply rest and soon fly on again, or he may cut loose and let his thread go on wherever the wind will carry it.

This is the explanation of the gossamer threads that in autumn cling to our clothes and faces and shimmer in the sunlight. Mr. Emerton, the author of an excellent little book on American spiders, also says that it is a common habit with some spiders, especially in October, to draw out a thread behind them as they walk along, and that this accounts for the attached threads commonly seen lacing together the pickets of a fence, or covering a field of grass, or clinging to the side of a barn. Another common habit with spiders is to let themselves down by threads from the branches of trees and so forth to the ground, and these hanging cables are blown about to add to the tenuous, silvery gossamer that is one of the exquisite ornaments of this most delightful of months. 


\section{October 26}

\section{CALENDAR FOR OCTOBER}

\section{MAMMALS}

Deer.-Seeking mates and gathering into bands.

Fur-bearers acquiring their winter coats.

Hibernating mammals disappearing.

Squirrels.-Gathering winter stores of nuts, etc.

Muskrats.-Begin their winter lodges.

(See also September and Norember)

\section{BIRDS}

Teals, W'ood Ducks, and Ruddy Ducks.-Pass South first fortnight.

Red-head.-Passes South irregularly.

Golden-eye and Buffe-head.-Depart last fortnight.

Scoter Ducks. - Arrive from the North.

Canada Geese.-Fly southward continuously.

Great Blue Heron.-Departs South irregu. larly.

Little Green IIeron. - Departs South first week.

Night Heron, or Quawk.-Departs South last week.

Rails and Coots.-Depart South first fort. night.

Phalaropes, and most Bay Birds. - Pass South.

Marsh Hawk, and other migratory Hawks.

- Pass South slowly in loose flocks.

Cuckoos. - Depart South last fortnight.

Sapsuckers. - Pass South first fortnight. 
Whippoorwills, Nisht Hawks, and Sivifts.Depart about the isth.

Humming-birl.-Departs South last week.

WVood Pequee.-Departs South tirst week.

Bobolink.-Departs South first weak.

Cow-bird and R'usty' Grakle.-1)epart South second week.

Savanna and Yillow-winged Sfarroivs, -Depart South third week.

Sea-side Sparroi's. - Depart south second week.

White-crozuned and White-throated Sparrows.

- Pass South last fortnight.

Tree Sparrow.-Arrives from the North second week.

Field Sparrow, Chewink, and l'ose-breasted Grosbeak.-Depart South last week.

Fox Sparrow. - Arrives from the North third week.

Indigo-bird.-Departs South last week.

Sarlet Tanager:-Departs South second week.

Tree Swallow's.-Disappear southward second week.

Northern Shrike.-Arrives from the North third week.

Red-eyed Vireo.-Departs South third week. White-eyed Vireo.-I)eparts South first week. Black-and-White, Parula, Black-throated Blue, Magnolia, Blackpoll, Blackburnian, and Redstart W' arblers. - I isappear before the I 5 th.

Yellow-rump and Black-throated Green Warblers. - Passing South.

Titlark.-Arrives from the North.

Oren-bird and Maryland Yellow-throat. - Depart South third week.

Cat-bird and House IVren. - Depart South second week. 

night; other thrushes earlier.

\section{REPTILES AND BATRACHIANS}

Going into winter-quarters ; Pickering's treetoad still noisy.

\section{FISHES}

Trout and other Salmonoids. -Spawning.

\section{INSECTS}

Brown Wasps. - Queens seek shelter in houses, logs, stumps, and other places for the period of hibernation; other forms die.

Hornets and Yellow-Jackets.-Queens find shelter in old nests or in other situations; drones and workers die.

Bumble-bies.-Drones and workers die; queens seek shelter in the nest or similar places on the ground.

Ants, - Species living in earthen nests retire to lower parts of the nest; others inactive.

lMud-riosps and Disser IVasps. - The few remaining adults die, learing only immature forms in the cells to live through the winter.

Ichnemmon-fies. - A few adults go in to hibernating quarters; many species winter over in the immature condition.

Ground Beetles.-Seek shelter under logs.

Ladybird Beetles. - Adults seek shelter in leaves about the bases of trees and in similar situations; many hundreds or even thousands of the same species will often congregate in such a place.

Black Blister - Beetles.-Adults die, leaving larvæ in the soil to live through the winter. 
May Bictles. - Some larva change to pupa and then to adults remaining in pupal cells; other larva burrow deeper into the soil.

Lons-horned Beetles. - Larva commonly burrow cleeper into the wood.

Housc Flic's. - Adults seek hibernating quarters in houses, barns, sheds, under bark, etc.

Compton Tortoise, Groy Comma, lied Admival, Painted Lady, Painted Beauty, and An. tiopa Butterfies. - Flying more or less during warmer weather, but seeking shelter for hibernation towards the end of the month.

Fall Canker-worm.-Noths appear and lay eggs on twigs of apple and elm trees.

Cutworms. - Larve find shelter in the soil or beneath rubbish at its surface.

Budworms, - Larra fasten their silken cases to the bark of twigs near the buds. 



\section{NOVEMBER}

“The year is dying, and the trees let fall With gentle lapse their faded leaves;

Sheeting the ground as with a funeral pall, Sombre and sad." 



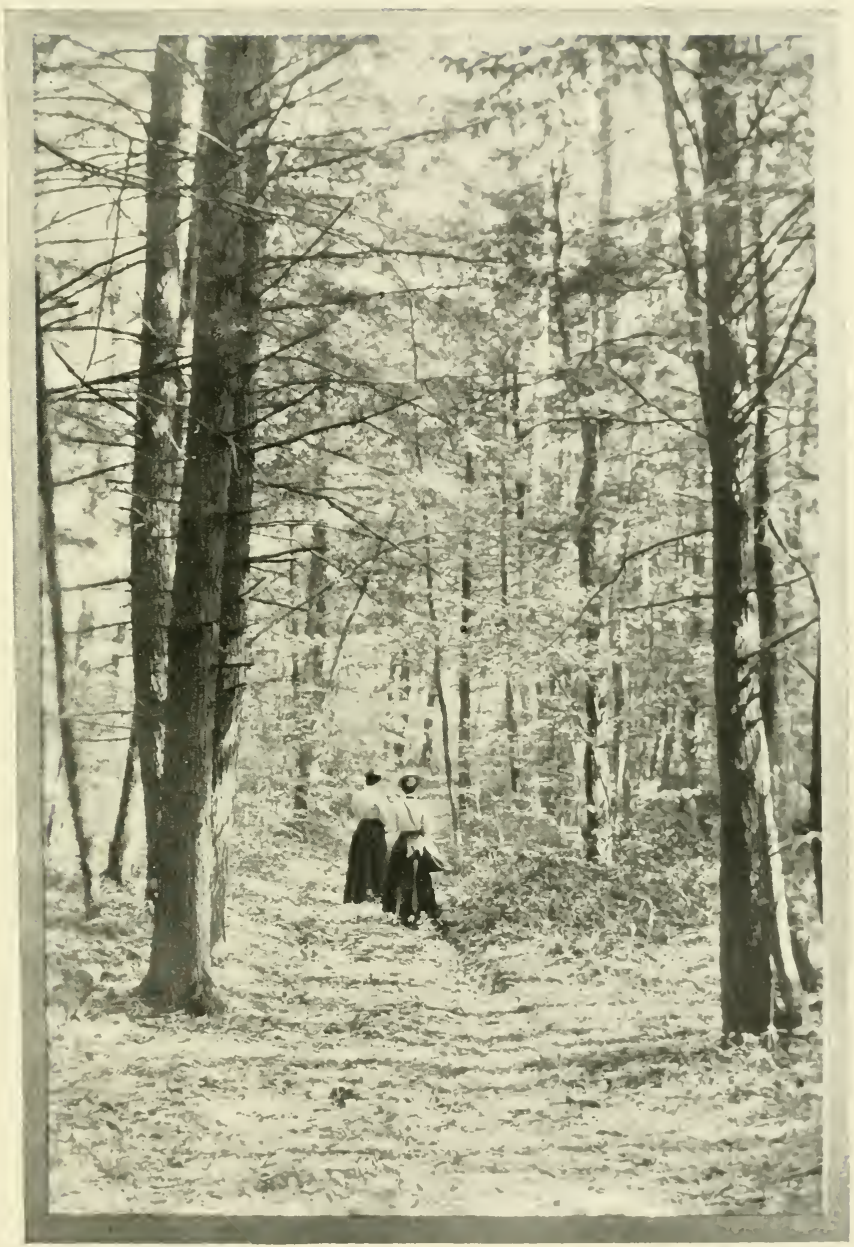




\section{NOVEMBER}

November, like March, is a struggling mixture of winter and summer. The moods of the month vary as the battle sways back and forth with the changing winds, and the legions of cold gradually win their way in their advance from the North. In Canada they are well encamped before the month is done, and the snowdrifts, like white tents, are heaped upon the plains and clog the paths of the woods; but in the Middle States only flurries of snow are usually seen, and frosts are rarely hard, though when I was a boy in southern Michigan we expected skating on Thanksgiving Day.

Tradition makes November a month of

" IVailing winds and naked woods And meadows brown and sere."

But this is largely English tradition, and doesn't fit our drier and sunnier climate, especially in the middle latitudes. It often happens that the greater part of the month is dry, cool, yet balmy and still and sweetly sunny, so that it is as delightful to be out-of-doors as in May.

Yet how different is the landscape and 
November 2 the feeling of the world from that in spring. There is perhaps more color in the picture of the woods and waters than in spring, but in place of the lush, strong painting of the fresh beginnings of the year there are now the mellow tints that come with age and decline of vitality. Look, for instance, at such a carpet as is spread under the cloudless sky over a level expanse like the great Hackensack meadows near New York, or some of the bay-side marshes along the Chesapeake. The reeds undulate beneath the breeze, with rustlings and clickings, in response to the white-edged wavelets that laugh along their stems. "Broad flickerings of subtle color-change," as I jotted into my notebook one day, "swept over the vast level morass. They were as delicate as the pulsations of the aurora or of the summer sea, when all the flags turned now their blades, now their edges, under the alternating pressure of the wind, or revealed for an instant the gleaming yellow of a thousand crowded stems; and nearer by were white feathery tufts and patches of warm color, where different plants and heather bushes grew, or the bright green of ditch margins traced in emerald the devious course of some tidal rivulet."

In such places the water has not yet been chilled much by the frosts that have browned and crinkled the flags and perfected the seeds, and life goes on much as in summer, but more quietly. The fishes 
are active, the amphibians awake but si-

lent, the turtles sleepily cluster upon dry spots, or climb upon exposed logs and snags to bask in the sun, and occasionally snakes creep out upon the shore to coil sluggishly on the warm rocks until the colder nights of the latter part of the month drive them underground, or force them into rotten stumps and hollow logs, where they will knot themselves into a torpid tangle until spring. Few serpents are to be seen after Thanksgiving Day.

In this month the mackerel-fishing ends, and such migrants as the bluefish, sheep'shead, sea-bass, and kingfish disappear, so that sea-shore angling is no longer attractive in the North. The codfishing, however, is beginning to be at its height, for at this season the cod visits the shallow waters of northern bays to deposit its eggs on the sandy banks and rocky ledges, and remains near them all winter. Inland the trout and its kindred are also on their spawning-beds-at the heads of streams, or beneath the rapidly forming ice of northern lakes.

Among the mammals, those which hibernate have mostly gone to rest, except, perhaps, the bears; and the squirrels are industriously completing their winter stores, while muskrat and beaver are putting the finishing touches to their houses. Sometimes, however, the muskrats do not begin to build until now, and then proceed slowly, keeping pace pretty 


\section{November 6}

well with the rising water. "The muskrats have added a new story to their houses since the last flood," Thoreau noted on one 9th of November. "They are uncommonly high; I think full four feet by five or more in diameter, a heaping cart-load. . . . I opened one. It was composed of coarse-grass, pontederia stems, etc., not altogether in mouthfuls. This was three and a half feet above water, others quite four. After taking off a foot I came to the chamber. It was a regularly formed oval or elliptical chamber, about eighteen inches the longest way, and seven or eight inches deep, shaped like a pebble, with smooth walls of the weeds, and bottomed or bedded with a very little drier grass-a mere coating of it. It would hold four or five, closely packed. The entrance, eight or nine inches wide, led directly from the water at an angle of $45^{\circ}$, and the walls are of such breadth at the bottom that the water in the gallery probably never freezes."

But the muskrat houses vary greatly in situation, form, and material; and frequently the animals will utilize a hollow stump, standing beside the water, and able to be entered from beneath the surface. In such a case they will roof over and cover up the stump until it is hidden altogether. I have read of a pair of muskrats doing the same thing with a stranded barrel that stood on its end in the water. Their greatest anxiety is in regard to the 
stability of the structure, and hence they November 8 often erect their houses upon platforms laid in a clump of swamp trees, like the black alder. Such architects, we are told by a New England observer, "exhibit a good deal of the constructive ability of the beaver, cutting their wood on shore in a similar mamner, and often towing it long distances to their building sites, where they wattle it firmly between the alder stems for a foundation." Such wellplaced cabins, composed mainly of cattails and twigs; may last and be continuously occupied for fifteen or twenty years.

When no fixed supports are taken advantage of, the ground is usually carefully prepared for a foundation. Choosing, for example, the end of a peninsula reaching into a marshy stream, the rats will dig off the soil to the level of the hard bottom of the stream, and begin work upon this denuded surface, which will support a part of the house, while the other half rests upon the bottoin of the creek. The materials will be gathered from the immediate neighborhood, thus clearing a considerable space about it. In some cases the foundation material consists of reeds and sticks laid regularly in a radiating manner from the centre to the circumference, and weighted with mud, making the firmest possible underpinning.

The study of the architecture of the muskrat derives special interest from the popular belief that the height of their 
houses indicates the length or rigor of the winter to come. Thus it is said that the muskrats build their houses twenty inches higher and very much warmer in early and long winters than in short ones. This idea gained credence from the observation of their habit of increasing the height of their houses as autumn advances, until the top is well above the ordinary level of the water or ice. Dr. C. C. Abbott, of Trenton, N. J., took the trouble to make careful notes of this matter for twenty vears, and found no relation whatever between the size and structure of the houses and the character of the winter.

Many weather prognostications relate to this month. Thus there is a quatrain, about the whiteness of a goose's breastbone, often repeated by old farmers :

"If the November goose-bone be thick So will the winter weather le;

If the November goose bone be thin

So will the winter weather be."

A heavy November snow, they say in New England, wiil last until April; and on the northern lakes they firmly believe that thunder and lightning in Norember foretells that the lakes will remain open until Christmas. There is also a proverb :

"As is the wind in the month of November, so will it be in the month of December." 
The saying that if we don't get our Indian summer in November we will get it in winter is of the same piece. Other prognostics are :

"As November 2 Ist, so the winter."

"As November, so the following March."

"Thunder in November indicates a fertile year to come."

"November take flail:

Let ships no more sail."

The deer wander in family parties, fattening upon food to be found in the woods, and especially upon what is left of the beech-mast. This is the month when the bucks seek their mates, and during this period their necks become enormously enlarged and their whole demeanor is changed. "Instead of treading cautiously through the forest," Merriam tells us, "they now rush wildly about, tracking the does by the scent; and when two or more bucks meet fierce conflicts ensue. In these engagements their antlers sometimes become interlocked, so that the combatants cannot free themselves, and both must inevitably perish. Audubon and Bachman state that they once saw three pairs of horns thus interlocked. What a wretched trio this must have been, slowly starving in the midst of plenty!

"At this season the bucks not only fight among themselves, but occasionally 
attack man, and more than one unfortunate person has been gored to death by them. In battle they make use of their horns, and also of the fore-feet, whose sharp hoofs are capable of inflicting terrible wounds. I was once sitting quietly on a $\log$ in a deer-park when a buck approached, and, making a sudden spring, dealt me such a powerful blow on the head with the hoofs of his fore-feet as to render me unconscious. No sooner was I thrown upon the ground than the vicious beast sprang upon me, and would doubtless have killed me outright had it not been for the intervention of a man who rushed at him with a club and drove him back.'

Fur-bearers have acquired their winter coats, and their pelts are in fine condition before the end of the month. The polar hare has turned white; but the ermine keeps his brown coat until the arrival of snow.

Now is the time to study the earth's preparation for winter. The sap which has been pumped by the vigorous process of growth into the extremities of herbs, shrubs, and trees, carrying stems to their utmost height, spreading leaves innumerable, increasing the bigness of all the bushes and trees by pushing out thousands of twigs is ceasing this work, withdrawing from leaves and twigs and bark, and is no longer produced by the roots. Growth stops, and the green coloring mat- 
ter undergoes a change similar to decay, which produces the other colors characNovember 16 teristic of the season.

October's brilliance has passed now, yet the essence of its color remains, in this sunset of the year, as the sky is often richly reddened after the sun has quite departed. The woods are far from leafless, but they have a much darker tone than in summer, and except where pines or hemlocks stand in copses, there is no distinct green. Instead, one sees browns and purples passing into one another by the loveliest gradations or pleasingly mingled.

It is when one enters the woods, however, that he begins to see that something new is to be learned of them at this season. Now is the time to study barks. One ought to know all the trees by their barks, and by the shape and manner of forking of the branches - the feathery, brushlike head of the birch; the ugly skeleton of the powdery-skinned poplars; the curled-in branches and twigs of the dogwood, are only suggestions of how characteristic is form in each sort of tree when unclothed.

But why do the leaves fall? The summer foliage is fastened on tightly enough, so that the July gales are more likely to break the branches than to strip them, and in autumn the greenery is shed long before the late storms tear the last of their coverings from the "tufted trees." Yet 
November 18 in the restful tranquillity of Indian summer days the woods are full of the shimmer of leaves fluttering down to lie crisp and rustling under your tread, or to be sent whirling by some frightened, whirring partridge.

Pick up one of these leaves and examine it. It is so dry you may perhaps pinch it to powder between your thumb and finger. It looks, and feels, and really is, dead, and at first thought that seems to explain its fall. But wait. Over there is a heap of brush cut last summer, but most of the leaves still cling to the severed branches. Observe that horn-beam down by the ridge, which was scorched by the fire in June. Its roots and trunk were killed, but all its leaves remain-no longer green, but still attached. Plainly, then, the death of a leaf is not necessarily follower by its falling, until it rots away. On the other hand, when the autumn is "late," warn, and moist, a great deal of foliage lets go before it has lost much greenness, and the presence or absence of frost seems really to have little to do with it.

It appears, then, that this process is one of natural severance between the leaf, stalk, and twig. This is the fact, and its cause is the pushing forward of a new leafbud underneath the point of attachment. Leaves spring upon trees only at definite points. Each successive set is placed precisely as was its predecessor, and for 
some reason nature has arranged that November 20 trees shall have an annual new set of leaves, just as animals have an annual (or semi-annual) suit of new fur; she replaces the old clothes as rapidly as possible. Old leaves fall, therefore, because their work is done, and they are pushed off by the growing buds slowly getting ready to take up the work of the next season. The process of severing is different in different trees; but this the reader may easily study for himself by examining the ends of leaf stalks and the places whence they drop, which are not, as he will notice, wounds at all.

Thus the autumnal falling of a leaf is not a matter for tears and doleful poens, but for hope and rejoicing, since it tells of another birth and exhibits how alive and energetic is the tree. Really, therefore, the beginning of the tree year is now. rather than in spring; for when the vernal warmth arrives it finds the trees well started and ready to take advantage of the first "growing weather."

Many flowers remain in bloom far into this month-mainly golden-rods, asters, and other of the coarser composites, but one belongs conspicuously to this month-the witch-hazel bloom-and botanists are not agreed whether to call this the latest flower of this year, or the earliest of the next. The leaves of the bush fall early, . and it is most curious to see this tough, angular, ugly skeleton of a shrub studded

November 2 I 
with rellow-green flowers, with petals resembling ribbons which shine against the sun like clusters of golden stars.

"Am surprised," Thoreau remarks on October 16th, "to find an abundance of witch-hazel now at the height of its change "; but in the lower Hudson valley this appearance does not come until November. "The tallest bushes," he continues, "are bare, though in bloom; but the lowest are full of leaves, many of them green, but chiefly clear and handsome yellow of various shades, from a pale lemon in the shade, or within the bush, to a darker and warmer yellow without. Some have even a hue of crimson; some are green with bright yellow along the veins."

The moths and butterflies have largely died, leaving eggs or cocoons to produce their kind in the spring, and other insects decrease rapidly as frosts increase, but many still live and enliven the sunny places. One hears the loud calling of the mole crickets, and hosts of gnats and tiny flies.dance in the yellow light. Everywhere, too, we catch the gleam of gossamer-mere streaks of glistening light, and our clothing and faces get covered with the silken fibres as we push through the weeds, that lend us more beggar's lice than we want.

But the most noticeable insects of this month, probably, are the crickets. They abound in open places like pastures, and as cold weather draws on all that persist 
huddle under boards and loose stones, where some live on torpidly until spring. November 24 Earlier than this they have been seen in large numbers beside the patbs, where the females thrust into the hard ground their ovipositors, which are tipped with a conical point, like an instrument used by well-drivers, and leave buried the yellowish oval eggs which will hatch next spring.

The shrilling of the crickets is one of the most characteristic sounds of autumn. and the Indian summer air often hums with it. This shrilling is made by the males alone. The venation of their wing covers is very different from that of the females' wings; the veins are fewer and the larger spaces between connected by a parcliment-like membrane. "If," says Prof. J. H. Comstock, "we examine under a magnifier the principal vein, which extends diagonally across the base of the wing cover, we shall see that it is furnished with ridges like those of a file. 'On the inner margin of the wing cover, a short distance towards the base from the end of the principal vein, there is a liardened portion which may be called the scraper. Each wing cover is therefore provided with a file and a scraper.... When the cricket wishes to make his call, he elevates his wing covers at an angle of about $45^{\circ}$ with the body ; then holding them in such a position that the scraper of one rests upon the file of the other. he moves the wing covers back and forth 
sidewise, so that the file and scraper rasp upon each other.' '

Substantially the same process and apparatus produce the similar sounds of the various locusts and grasshoppers, which are near relatives of the crickets and some of which are still heard.

In respect to one of them some interesting facts may be learned at this season. If you will examine the canes of the raspberries in your garden, you are likely to find one, here and there, marked with a long sinuous scar. Split open such a cane, and you will find beneath each of the line of punctures that forms the scar a long, cucumber-shaped, yellowish egg ; and sometimes forty or fifty of these eggs will fill the hollow of the cane-pith packed side by sıde, like a bunch of cigars, stored until spring. These are the eggs of the snowy cricket, a near relative of the common crickets, but ivory white. with almost transparent wings, and in habiting trees and shrubs instead of the ground. It feeds largely on the plant-lice (aphides), whose eggs now form patches upon the roots, bark, or twigs of trees in vast numbers, prepared for hibernation, and forming a large part of the winter fare of certain small birds, especially the chicadee. Grape-vines, plum twigs, and some other garden shrubs are bored by the snowy tree crickets in this way, and now and then considerable damage results. 


\section{CALENDAR FOR NOVEMBER}

\section{MAMMALS}

Deer.-Choosing their mates and herding in the forests where, northerly, the snow is beginning to limit their wanderings.

Fur-bearers wearing new and finest coats.

Hibernating mammals going into dormancy.

Squirrels. - Completing their winter stores.

\section{BIRDS}

Sea Ducks.-Pass South first fortnight.

Woodicok ard a few Bay-birds. - Linger until the end of the month on their way south.

Mourning Dove. - Departs South third week.

Kingfisher.-Departs South second week.

Phabe-bird-Departs South first week.

Red-rvinged Blackbirds. - Flock extensively in the marshes, and disappear third week.

Meadow Lark. - Departs South last week.

Purple Grakle.-Departs South first week.

Vesper and Chipping Sparrows. - Depart first week; but many of the former (Poöcetis) stay through the winter south of the Hudson Highlands.

Swamp Sparrow. - Departs South second week.

Song Sparrows. - Some go southward and others come from the North this month, but the species is present in most localities all winter.

Fox Sparrow. - Departs South third week.

Myrtle-birds. - Depart South second week.

Titlark and Hermit 7 hrush. - Depart second week. 
Winter visitors begin to arrive from the North irregularly, according to boreal weather conditions.

\section{BATRACHIANS AND REPTILES}

Retired for the winter.

\section{FISHES}

Fresh-water fishes descending streams or leaving lake shores for deep water.

Sea fishes leaving the shore for deep water, or departing southward.

Trout and Salmonoids.-Spawning.

Codfish. - Approach the shore and begin to spawr.

Various marine invertebrates spawning.

\section{INSECTS}

See Calendars for October and January.) 


\section{DECEM BER}

"The year is wearing to its wane, An' the day is fading west awa'." 



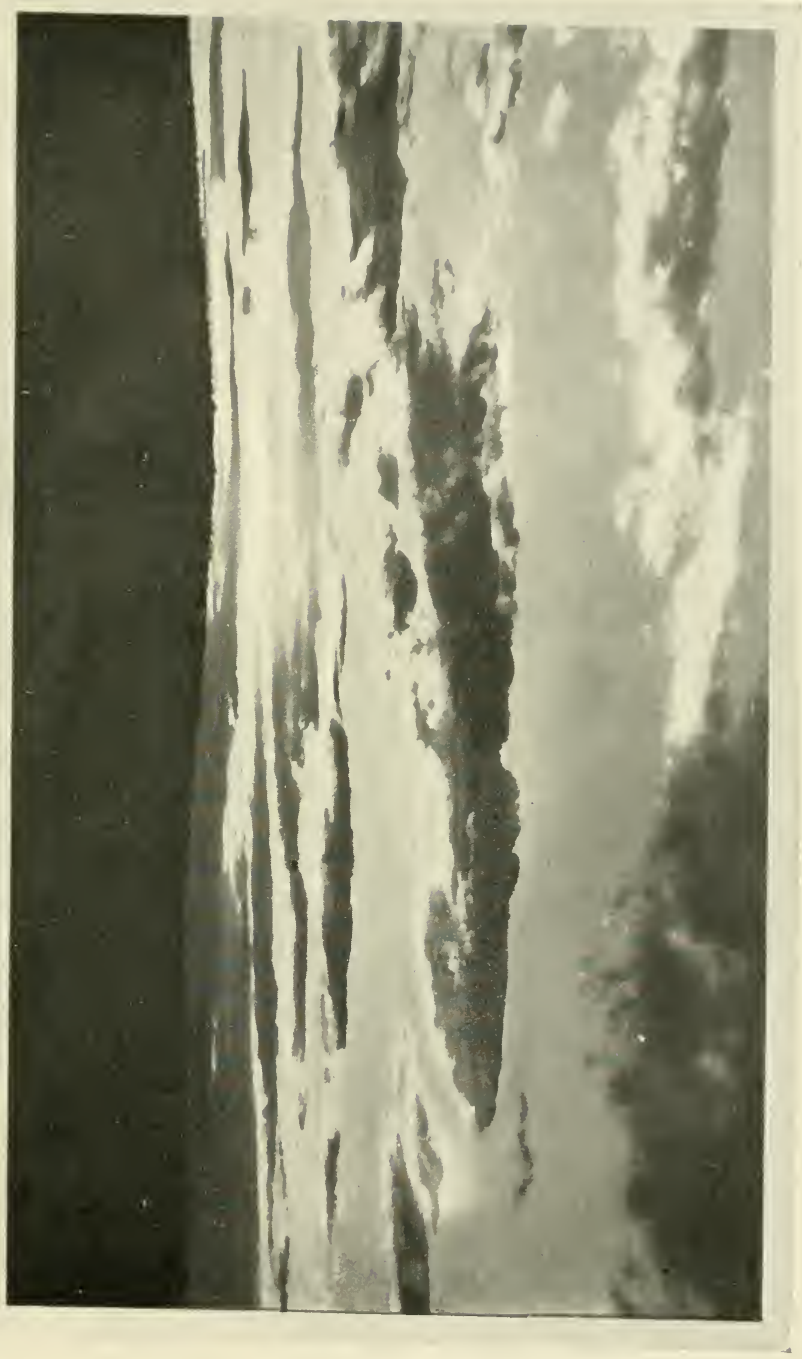




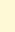




\section{DECEMBER}

DECEMBER ushers in the winter some-

times hurriedly and sometimes tardily, but nature is ready in time if snows and cold come early, or is content to wait when they are late. She begins early to make her preparations for an average season, and an excessive winter, which now and then overcomes her defences and extensively kills vegetation and animal life, is one of the ways by which nature in a larger sense lops off a weak or surplus form and trims down the world of life to normal proportions. Extra hard winters, sunimers of drouth, and similar periods of stress are among the instruments of natural selection in getting rid of the least efficient and so raising the general average. The plagues and wars and wide-spread catastrophes that scar human history are, in a large way, beneficent to the human race, as a whole, in the same manner.

The special preparations made to endure the cold are many and ingenious. Such, the botanists say, are the thick scales on the buds of the early leafing trees; and there is many another provision to protect the tender inner parts 


\section{December 2}

from influences of moisture and temperature until it shall be safe to throw aside their coverings (which then wither and drop away) and push out into freedom. To ward off moisture more effectually, as Gray tells us, buds are sometimes coated with a waxy, resinous, or balsamic exudation, conspicuous on the scales of the horse-chestnut, balsamic poplar (or balm of Gilead), and balsam fir. To guard against sudden changes of temperature, they are often lined with a down or wool that is a poor conductor of cold or heat, it serving the same purpose as the underfur of animals.

How the small invertebrate creatures prepare for the long period of cold and famine formed the theme of the remarks upon January; but more might then have been said, perhaps, as to the thick, warm coverings that certain insects throw around thenselves, such as the woolly aphides and the many dense cocoons of all sorts in which pupæ pass the winter; and were there space to go into details, one might describe interestingly, no doubt, many curious ways in which larvæ are provided with, or make for themselves, snug winter-quarters. Thus the caterpillars of our "white admirals" (butterflies of the common and wide-spread genus Busilarchia, which are among the earliest to appear in the spring) are hatched from eggs laid upon the tip of a leaf of some forest or orchard tree. "The infant

\section{December 3}


caterpillar," says Holland, "feeding upon the leaf in immediate proximity to the December 4 point where it has been hatched, attaches bits of bitten leaf to the midrib by strands of silk, thus stiffening its perch and preventing its curling as the rib dries. Out of bits of leaves thus detached it constructs a packet of material, which it moves forward along the midrib until it has completed its second molt. By this time winter begins to come on, and it cuts away for itself the material of the leaf on either side of the rib, from the tip towards the base, glues the rib of the leaf to the stem by means of silk, draws together the edges of the remaining portion of the leaf, and constructs a tube-like hibernaculum, or winter-quarters, exactly fitting the body, in which it passes the winter."

- The same entomologist also calls attention to a matter which will suggest a field of experiment to students, in the following paragraph :

"The effect of cold suddenly applied to the chrysalids of butterflies at the moment of pupation is often to produce remarkable changes in the markings. The spots upon the wings of butterflies emerging from chrysalids thus treated are frequently rendered more or less indistinct and blurred. The dark markings are intensified in color and enlarged; the pale markings are also in some cases ascertained to experience enlargement. Many of the 
strange and beautiful aberrations known to collectors have no doubt been produced by the action of frost which has occurred at the season when the larva was pupating. The species believed by the writer to be most prolific in aberrations are species which pupate early in the spring from caterpillars which have hibernated or which pupate late in the autumn. Some are species found at considerable altitudes above sea-level, where late frosts and early frosts are apt to occur."

The semi-annual change of plumage in birds, and of pelage in mammals, is an adaptation to the alternating periods of heat and cold that make up the year. The winter plumage of our northern birds, such as may be seen in a mid-December ramble, is denser and more closeiy interlocked than that which follows the spring molt, and it is almost always duller in hue, too, and hence lessconspicuous. The ducks and related birds have a downy undergrowth, which not only serves the main purpose of preventing water reaching the breast, but also serves to resist cold. It is this underwear of down, which loosens in the spring and is gradually dispensed with, that is plucked out and utilized by the female ducks as bedding for their eggs. The down obtained from the nests of the eider-duck, and justly regarded as a luxury by us for its lightness and warmth, is the special undercoat assumed by that arctic fowl for winter, which, 
when it is naturally discarded in the spring, is applied to a secondary utility, December 8 and forms a blanket for the duck's eggs and young. We are really using thirdhand material.

Birds sumetimes acquire at this time of the year special parts of aid to them during the impending bad season. Thus there grows on the toes of the ruffed grouse, in the late fall, fringes of sharp points which act as snowshoes, enabling it to run over the snowdrifts and hunt for buds, cones, berries, and catkins, and at night to paw its way into a drift and lie. there, well sheltered, as are the habits of the bird in northerly regions. The feathers which clothe the feet of the ptarmigan, whose home is on lofty mountain-tops, or in the snowy North, are much broader and stiffer in winter than in summer, thus forming real snowshoes. Both of these birds scratch deeply in the snow for evergreen leaves and clinging berries lying close to the warm ground underneath, such as the wintergreen, partridge berry, creeping snowberry, and, in the far North, the numerous and abundant sorts of cranberries. All these fruits mature late in the fall and hang on until spring--a storehouse of food for birds and deer.

Apropos of this, it will be pertinent to quote a paragraph from Signs and Seasons, in which Mr. John Burroughs discourses as follows:

"It is plain why the sugar-berry, or 
December Io lotus, holds its drupes all winter : it is in order that the birds may come and sow the seed. The berries are like small gravel stones with a sugar coating, and a bird will not eat them till he is pretty hard pressed, but in late fall and winter the robins, cedar-birds, and bluebirds devour them readily, and, of course, lend their wings to scatter the seed far and wide. The same is true of the juniper berries and the fruit of the bitter-sweet. In certain other cases, where the fruit tends to hang on during the winter, as with the bladder nut and the honey locust [eaten by squirrels occasionally], it is probably because the frost and the perpetual moisture of the ground would rot or kill the germ. To beech - nuts, chest. nuts, and acorns the moisture of the ground and the covering seems congenial, though too much warmth or moisture often causes the acorns to germinate prematurely. I have found the ground under the oaks in December covered with nuts, all anchored by purple sprouts. But the winter which follows such untimely growths generally proves fatal to them."

A provision very similar to that of the grouse is made for the feet of some small mammals that stay abroad, such as our northern rabbit, along the margins of whose feet the hairs grow so long and stiff that a Western relative is called the snowshoe rabbit.

It is a variety of the American northern 
or "varying" hare which is so called because it turns white in winter. This is the case with many creatures of the regions where the snowfall is deep and lasting. The ptarmigans are plentifully brown in summer, but in winter altogether white in plumage, except certain tail feathers. The same is true of the snow bunting and of the great snowy owl, one of the fiercest predatory birds of the Canadian zone.

Certain mammals have the same experience. The arctic bear and arctic fox are always white, for they inhabit the regions of endless snow; but the big Northern hare divells in summer as far south as our northern boundary, and in summer is reddish-brown. Weasels are familiar to us in their red-brown summer coats, with white only inside the legs and on the belly; but in winter this brown is replaced by white, and the weasel, or stoat, becomes the "ermine," so valuable as a fur.

Now this change is a preparation for winter life in two ways, and it is accomplished, in the case of the weasel at least, by a quick whitehing of the hair itself, immediately following the first fall of snow ; the same kind of weasels that live south of snowy regions do not change at all, and those which live, say about New York, where in some winters no snow of any account falls until late in the season, delay their change until it comes and then become white in a few hours. 
December 14
Such a change of feathers or fur to white may be helpful in two ways. First, it no doubt tends to an increase of warmth, the white hair preventing loss of heat better than the more absorbent black hair. A more important service, however, is the concealment the colorlessness of the animal affords it in a world of white, where any creature of a dark color would be conspicuous to its enemies a long distance off.

A suggestive note on this point occurs in Little Beasts of Field and Wood, by William E. Cram, who says :

"Late in the autumn, or early in the winter, the ermine changes from reddish brown to white, sometimes slightly washed with greenish yellow or cream color, and again as brilliantly white as anything in nature or art; the end of the tail, however, remains intensely black, and at first thought might be supposed to make the animal conspicuous on the white background of snow, but in reality has just the opposite effect. Place an ermine on newfallen snow in such a way that it casts no shadow, and you will find that the black point holds your eye in spite of yourself, and that at a little distance it is quite impossible to follow the outline of the weasel itself. Cover the tail with snow and you can begin to make out the position of the rest of the animal; but as long as the tip of the tail is in sight you see that and that only." 
Such boreal weaklings as the ptarmigan and the snow buntings, which must seek their food on the surface by daylight, would be pounced upon by hawks, owls, weasels, foxes, etc., were they not rendered alnuost invisible by their colorless attire; but 1 is to be noted that they, too, keep some points of dark color, as do the weasels. One may read a learned discussion of this matter in the "Bulletin of the American Museum of Natural History," volume vi., page 107.

The fur and pelts of all the mammals are now in their best condition, and this is the most profitable month to the trapper, who must brave its rigors by constantly visiting his traps if he would thrive in business. The deer are wearing their longest and densest coats, and the fur of fur-bearing animals is long and close, and most richly colored. This is partly due to the special provision given them against winter's cold by an undersuit of very dense short hairs sprouting among the roots of the longer and true fur, especially noticeable in such animals as the mountain goats, where it forms a fleecy mass called pashm-a Himalayan word. It is from this substance that the warm and beautiful fabrics of Kashmir and neighboring countries are made, and there it is known as shawl wool.

The hibernating mammals have long since gone to sleep, and those which are half awake in their well-stored homes, 
like the chipmunk, no longer find any warm days in which to walk abroad. The latest to retire, probably, is the black bear. "The time of his hibernation," to quote Mathews, "is almost entirely dependent upon the condition of the food-supply. If food is scarce and the cold is severe, he retires about the first of December; but if beech-nuts are plenty and the weather is mild, he will prowl about all winter, and the female will den only before the period of bringing forth the young."

Dr. Merriam, who has had much experience with bears in northern New York, makes the same statement, and asserts that the cause of retirement is not "to escape either the low temperature or the deep snows, but to thus bridge over a period when, if active, he would be unable to procure sufficient food."

The den Dr. Merriam describes as usually a partial excavation under the upturned roots of a fallen tree, or under a pile of logs, with perhaps a few bushes and leaves scraped together by way of a bed, while to the first snow-storm is left the task of completing the roof and filling the remaining chinks. Not infrequently the den is a great hole or cave dug into the side of a knoll, and generally under some standing tree, whose roots serve as side-posts to the entrance. The amount of labor bestowed upon it depends upon the length of time the bear expects to hibernate. If the prospects 
point towards a severe winter and there is a scarcity of food, they den early and take pains to make a comfortable nest; but when they stay out late, and then den in a hurry, they do not take the trouble to fix up their nests at all. At such times they simply crawl into any convenient shelter, without gathering so much as a bunch of moss to soften their bed. Snow completes the covering. and as their breath condenses and freezes into it, an icy wall begins to form, and increases in thickness and extent day by day till they are soon unable to escape, even if they would, and are obliged to wait in this icy chill till liberated by the sun in April or May.

The case is much the same with the deer. When the winter is open, and the snow not very deep, they wander about incessantly, and often, in frontier regions, come among the cattle and even approach the haystack or barn, driven by hunger; but in seasons or places of heavy snowfall their wanderings are restricted to the limited locality, or paths, they are able to keep trampled down, and for food they must rely upon the leaves of the trees (mainly spruce) and bushes which they browse clean. Such trampled places of confinement are called "yards," and are formed by the Eastern deer and the moose; but the caribou, by reason of their broad hoofs, can move about upon the snow. and are able to paw down through it, no 


\section{December 22}

matter how deep (as do the Lapland reindeer) to get at the moss and berries beneath it.

"Now for short days and early twilight," exclaims Thoreau, "in which I hear the sound of wood-chopping. The sun goes down behind a low cloud and the world is darkened. The partridge is budding on the apple-tree and bursts away from the path-side. . . A As I walk along the side of the hill a pair of nuthatches flit by towarls a walnut-tree, flying low in mid-course, and then ascending to the tree. I hear one's faint tut-tut or quahquah (no doubt heard a good way off by its mate, now flown to the next tree) as it is ascending the trunk or branch of a walnut in a zigzag manner, wriggling along, prying into the crevices of the bark; and now it has found a savory morsel which it pauses to devour; then flits to a new bough."

By the time the cold weather of the month has really set in, an ornithologist who lives in the northern part of the United States finds many new birds awaiting his walks, and usually inclined to be friendly to his advances. Sometimes these appear very early, which is an indication that extra severe weather is prevailing in boreal regions, and then it is safe to guess that our own winter will be colder than usual.

Among the greater rarities occasionally seen from December to March is the Bo- 
hemian waxwing, a bird of the same genus

as our cedar-bird, but larger and almost restricted to the arctic coasts, where it makes its nest long before the snow has left the forests; few birds, even here, breed so early as does this handsome waxwing in the forests about Hudson Bay, in Alaska, Siberia, or Lapland. Crossbills now and then visit us in winter in the course of their irregular wanderings, and please us with their parrot-like antics among the evergreen woods. This, however, is only one of several Northern cone-billed winter visitors. Along the sea-coast and on open areas, from New England westward to Iowa, the snow bunting, or snowflake, comes riding upon the first severe gale from the North, and usually brings with it the richly colored Lapland longspur and the horned lark. At this seasßn, too, may frequently be seen the great Northern shrike, more dreaded than a hawk or an owl by the little tree sparrows (Northern cousins of the chippy), the sprightly golden-crowned kinglets (hardly bigger than a hummingbird, yet of arctic habitat), the redpoll, whose rosy breast looks like a flower amid the dark foliage of the spruces he frequents, and the winter wren, whose song, briefly heard in early spring, is one of the surprises of the season.

All these and some others, especially among the sea-fowl, are rarities from the far North, which will be seen only by dili- 
December 26

December 27 gent and keen-eyed observers at irregular intervals; but there is a long list, as has been mentioned elsewhere, of resident birds that stay through the cold weather or come to us in great numbers from Canada.

But one need not seek for these rarities, thinking that otherwise there is nothing to study. There are lots of things to be learned about our common winter birds, such as the woodpeckers. John Burroughs was quite right in his assertion that "it seems not to be generally known" that certain of our woodpeckers-probably all the winter residents-each fall excavate a limb or the trunk of a tree in which to pass the winter, and that the cavity is abandoned in the spring, probably for a new one in which nidification takes place. "So far as I have observed," he remarks, "these cavities are drilled out only by the males. Where the females take up their quarters I am not so well informed, though I expect that they use the abandoned holes of the males of the previous year." . . Such a cavity makes a snugr, warm home, and when the entrance is on the underside of the limb, as is usual, the wind and snow cannot reach the occupant:"

It remained for a still more recent time, and for another unprofessional birdobserver to teach us the food of the chickadee, whose winter hardihood has been so much admired. It finds an abun. 
dance of dormant insect life and insect eggs, but the main part of its fare consists of aphides. So says Professor IVeed: "Forty-one specimens [of chickadees] were studied from November, 1897, to March, 1898. Results show that this bird feeds on a great variety of insects. The most striking kind of food was eggs of aphides - twenty-one per cent. of the whole. Insects, as a class, constituted fifty-one per cent.; spiders and their eggs, five per cent.; vegetable matter, twentyeight per cent:; of this twenty per cent. consisted of buds and bud-scales, introduced accidentally with aphid eggs."

These two are excellent examples of winter bird-studies that may be made by any one.

We have now followed the circle of the year round to its calendar, beginning in January, and have found that it all moves together, the revival of vegetation under the spring sun being the signal for the awakening of animal life and the renewal of its energies, and its progress from leaf to flower, and then to fruit, being accompanied by the development of the various creatures that depend upon it for food. Each year is a grand illustration of the interdependence of all nature; of the exact adjustment of each creature to the other creatures of its locality and to their surroundings, and of the uniformity of law. 


\section{CALENDAR FOR DECEMBER}

\section{MAMMALS}

Hibernating animals sound asleep.

Mice and small Rodents.-In snug retreats. Northern Hare.-Turns white.

Bears.-Retiring to their clens, early or late, according to the weather.

Small fur-bearing carnivores, bold, active, and far-wandering in search of prey; coats in the best of condition.

Ermine Weasels, - Turn white at the coming of the first snow-storm.

Deer._- "Yarding" in forests.

\section{BIRDS}

Arctic visitors arrive irregularly, and in more or less abundance according to severity of weather. See January Calendar.

BATRACIIINS AND REPTII.ES

A few frogs and salamanders half alive ir. warm spring-holes.

\section{FISHES}

See November and February Calendars.

$$
\text { INSECTS }
$$

See January Calendar. 






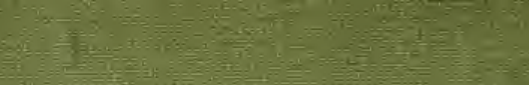

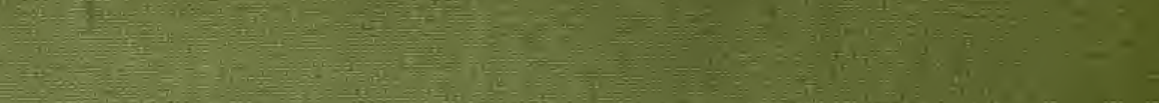

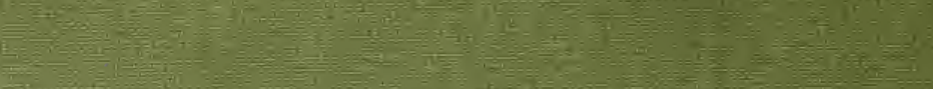

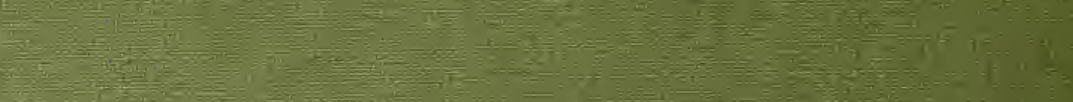

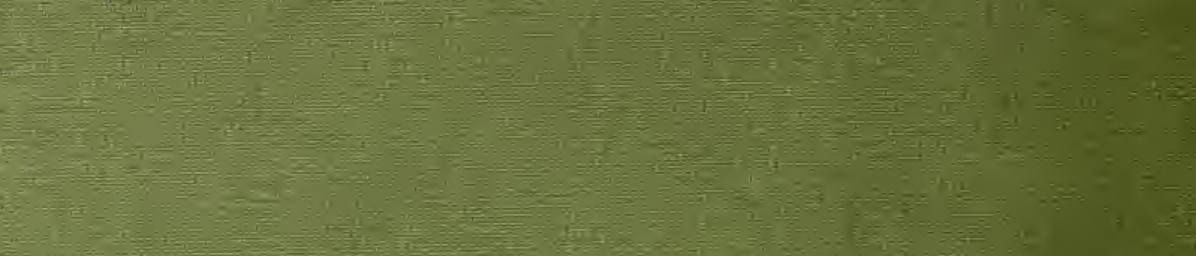

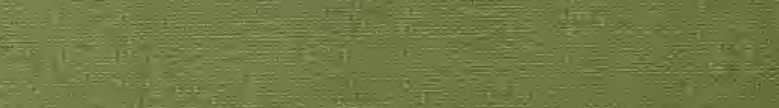

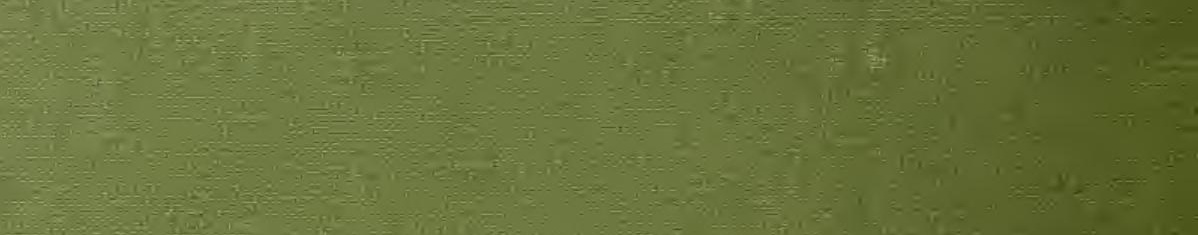

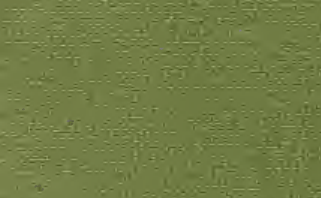

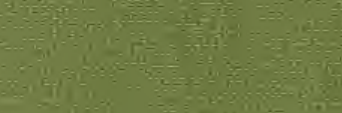
tis:

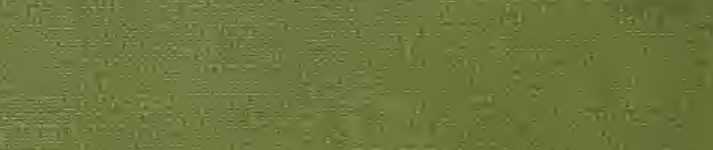

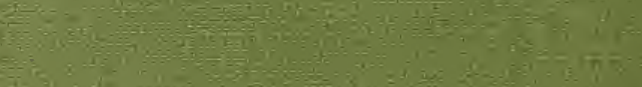
and

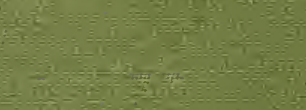

thent

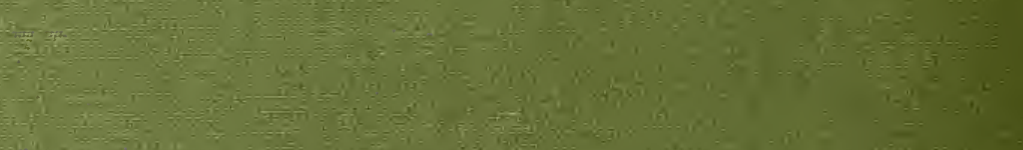

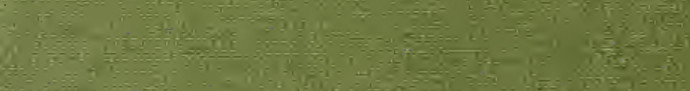

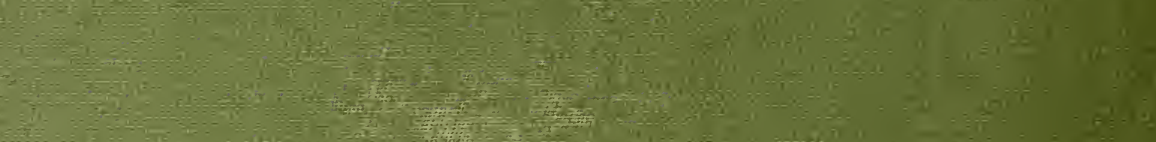

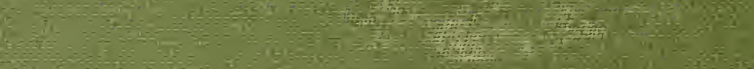
ats

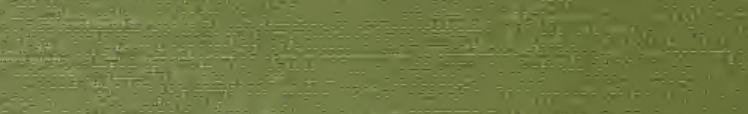
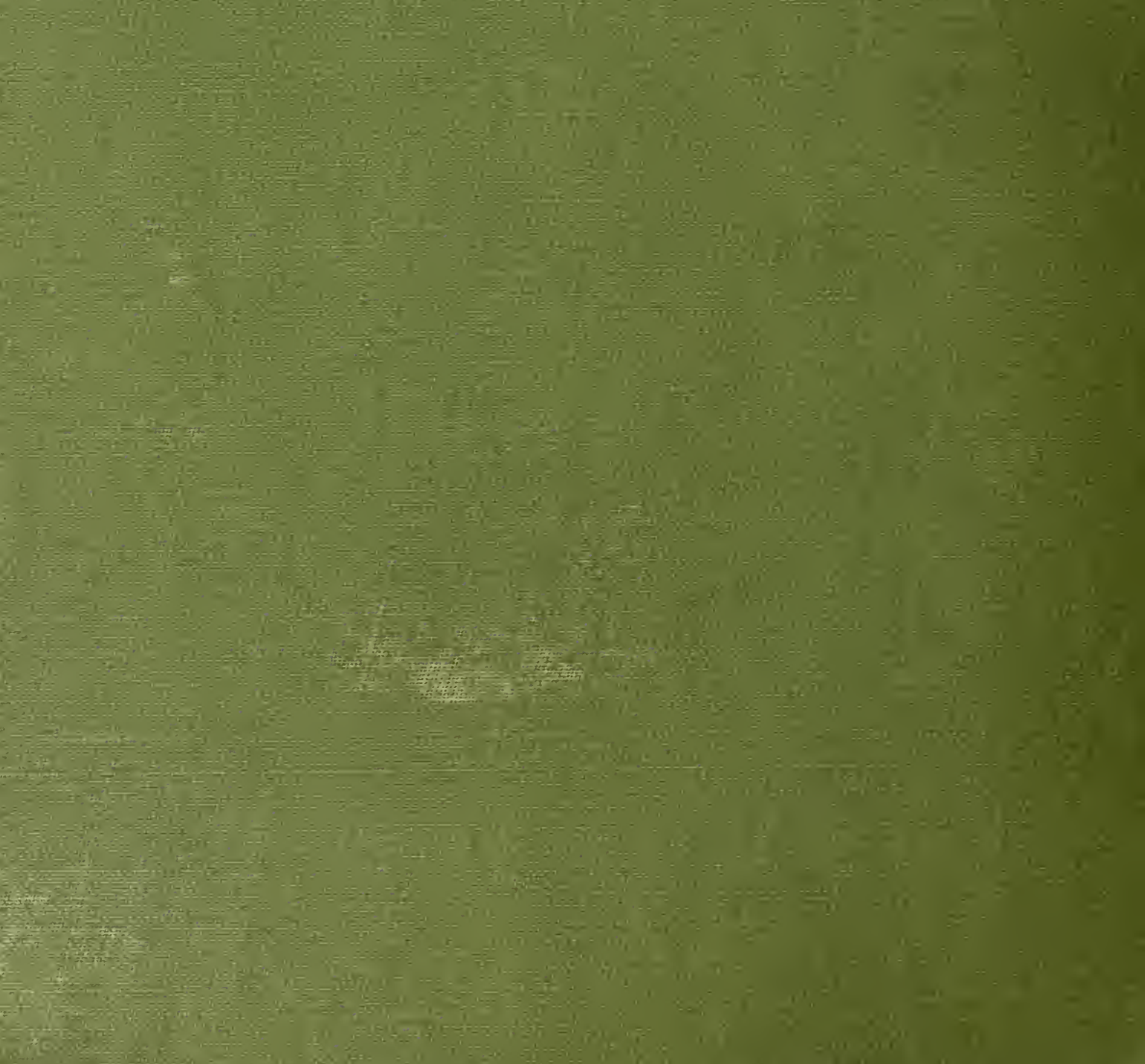